\title{
De la norme lingvistice la o Limbă Standard: Cazul limbii grecești moderne
}

\author{
Spiros A. Moschonas ${ }^{\star}$ \\ Departamentul de Studii ale Comunicării și Mass-Media, Universitatea Națională și Capodistriană din Atena, \\ 1 Sofocleous Str., 10559 Atena, Grecia
}

\section{Despre articol}

Istoric:

Primit 1 iulie 2019

Acceptat 12 august 2019

Publicat 7 noiembrie 2019

Cuvinte-cheie:

istoria limbii

pragmatică

sociolingvistică

\section{Rezumat}

Studiul de față urmărește schimbările din varianta standard a limbii plecînd de la schimbările de la nivelul multiplelor norme ale acestei variante. Are în vedere mai ales procesul continuu de standardizare a limbii grecești moderne și pune în discuție: a) schimbarea inițială în privința planificării lingvistice, ce a cuprins trecerea de la codificarea limbii grecești moderne propusă de Jannnis Psycharis spre o codificare mai „permisivă” propusă de Manolis Triandaphyllidis; b) propagarea normelor lingvistice la nivelul maselor prin presă și prin mijloace electronice, după promulgarea legii privind „Chestiunea Limbii Grecești”; c) procesul „de-idiologizării” sau „naturalizării” normelor; d) un relativ recent caz de stilizare a unei forme lingvistice intens recomandate ca normă (nazalizarea consoanelor oclusive sonore), situație care probabil că reprezintă o nouă fază a procesului de standardizare.

Cele patru cazuri de norme variabile sînt discutate în interiorul teoriei performative a standardizării. Am recurs la abordarea întemeiată pe studiul de corpus, urmărind instanțe corective (acte metalingvistice de limbaj, de tipul: „nu se va spune, nici nu se va scrie $X$; se va spune și se va scrie $\left.Y^{\prime \prime}\right)$ și permisive („se poate spune sau scrie atît $\mathrm{X}$, cît și $\mathrm{Y}$, cu condiția ca C”). Asemenea triplete apar în texte care prescriu uzul lingvistic. Am luat în considerare mai multe tipuri de texte: gramatici oficiale, articole de cultivare a limbii apărute în presă, emisiuni de radio și televiziune, ghiduri de exprimare adresate atît publicului larg, cît și profesioniștilor care lucrează în media.

Am arătat că instanțele permisive și/sau corective formează repertorii care se schimbă de-a lungul timpului. Asemenea schimbări la nivelul normelor lingvistice produc schimbări la nivelul limbii standard. În concordanță cu teoria performativă, limbile standard sînt supuse restandardizării pe măsură ce normele lingvistice sînt supuse redefinirii. Schimbările de la nivelul repertoriilor corective sînt mărturii ale unui proces de continuă standardizare a limbii grecești moderne. Acest proces apare ca fiind mediat, i.e., a influențat și a fost influențat de practici prescriptive din mediul tipărit și al comunicării electronice de masă.

\section{Cuprins}

$\mathbf{0}$ Introducere $\quad 2$

1 Planificare $\quad 6$

$\begin{array}{llr}2 & \text { Repertorii } & 17\end{array}$

3 Ideologie $r$

4 Stil

5 Concluzii și discutiii

Bibliografie

*Adresă de corespondență: smoschon@media.uoa.gr. 


\section{Introducere}

O limbă standard poate fi, de fapt, unul din trei lucruri: (a) o limbă; (b) un standard; (c) o limbă și un standard, deopotrivă ${ }^{1}$.

(a). Dacă ne luăm după cele mai populare lucrări de vîrf în sociolingvistică, precum: cuprinzătoarele introduceri în sociolingvistică (ale lui, e.g., Trudgill, 1983, p. 17-20; Hudson, 1980, p. 32-34; Wardaugh, 1998, p. 29-37; Holmes, 2008, p. 76-78, p. 137-138; etc.), enciclopediile delingvistică (e.g., Inoue, 2006; Haugen, 2001; dar cf. Linn, 2011), și alte opere similare, rezultă că (a) reprezintă viziunea dominantă printre sociolingviști. Un standard, desigur, nu este considerat, nici măcar în manualele introductive, 'o limbă în sensul deplin al cuvîntului. Pentru lingviști, limbile sînt, la urma urmei, entităţi false, iar dintre toate aceste entități false, limbile standard sînt, după Hudson (1980, p. 34), „cele mai puțin interesante”. Limbile standard sînt mai cu seamă limbi scrise; se consideră că sînt mai degrabă unitare decît variabile; și numai o parte a populației are acces la ele. Un standard, „orice o fi el, este mai puțin decît o limbă” (Trudgill, 1999, p. 118).

Să încadrăm acum perspectiva (a) în jargonul potrivit. Un standard este o 'varietate' particulară, sau o 'subvarietate' a unei limbi, sau un 'dialect' printre alte dialecte. O varietate standard, dacă este o varietate într-adevăr, nu trebuie evaluată în raport cu un set oarecare de reguli prescriptive sau cu oricare ideologie lingvistică (Trudgill, 1999, p. 118, 125); i.e., o limbă standard nu trebuie evaluată în funcție de niciun standard particular. Se formulează uneori clauza condițională că această varietate este „una pur socială”, neasociată cu vreo zonă geografică aparte și avind numai o slabă componentă variabilă geografic (Trudgill, 1999; 1983, p. 17-20; 2003, p. 128).

Cu totul interesant, perspectiva (a), cea care identifică o limbă standard mai degrabă cu o varietate particulară decît cu un standard (prescriptiv) (sau cu o normă), nu este întîlnită numai în rîndul sociolingviștilor; ea este împărtășită—unanim, cred eu—de promotorii sau „fondatorii” a numeroase „limbi standard", fie ei lingviști sau nu, care de obicei identifică o limbă standard-preferată de ei înşişi-nu cu „o varietate pur socială”, ci mai degrabă cu o koine locală sau supra-locală preexistentă (cîteva exemple pot fi găsite la, e.g., Fodor \& Hagège, 1983-1990; cazul unei koine grecești moderne urmează a fi analizat mai jos).

(b). Spre deosebire de (a), (b) consideră că o limbă standard este nimic mai mult decît un standard (o ideologie, o credință, un construct, un ideal, o normă, un set de reguli prescriptive), iar nu o varietate particulară. Această concepție este atribuită adesea lui Milroy \& Milroy (1999, p. 19), care consideră că

it seems appropriate to speak more abstractly of standardization as an ideology, and a standard language as an idea in the mind rather than a reality - a set of abstract norms to which actual usage may conform to a greater or lesser extent.

[rom.: este mai potrivit să se vorbească în termeni mai abstracți despre standardizare ca ideologie și despre o limbă standard ca idee, decît ca realitate - un set de norme abstracte căruia uzul real i se conformează mai mult sau mai puțin.]

În aceeași direcție, Lippi-Green (2012, p. 67) definește o „standard language ideology” [rom.: o ideologie a limbii standard] ca „a bias toward an abstracted, idealized, homogeneous spoken language” [rom.: prejudecată înclinată în favoarea unei limbi vorbite abstracte, idealizate, omogene], care „names as its model the written language, but [...] is drawn primarily from the spoken language of the upper middle class $\mathbb{Z}$ [rom: își desemnează modelul ca fiind limba scrisă, dar ... care este întemeiată mai ales pe limba vorbită a clasei superioare]. Deși „abstractă” și „idealizată”, o atare limbă—pretinde autoarea-poate fi „imposed and maintained by dominant bloc institutions” [rom.: impusă și menţinută pe cale instituţională].

\footnotetext{
${ }^{1}$ Există și o a patra posibilitate: (d) nici una, nici alta—care nu poate fi exclusă $a$ priori; dar nici nu putem să contemplăm ab init. posibilitatea că ne aflăm în eroare.
} 
La fel, o limbă standard este, în primul rînd, ceea ce se consideră a fi un standard, și, în al doilea rînd, ceea ce devine în urma faptului că este impusă în uzul lingvistic propriu-zis. Deși nu este predominantă, concepția că limbile standard reprezintă mai degrabă standarde supra-impuse, decît (sub-)limbi reale, își face loc în lucrările de specialitate; Fromkin, Rodman \& Hyams (2011, p. 440), vorbind despre Engleza Americană Standard (EAS), afirmă că „SAE [Standard American English] is an idealization. Nobody speaks this dialect; and if somebody did, we would not know it, because SAE is not defined precisely" [rom.: EAS este o idealizare. Nimeni nu întrebuințează acest dialect; iar dacă l-ar întrebuința cineva, nu am ști, pentru că EAS nu este definită precis].

În concordanță cu (b), aşadar, o limbă standard este mai ales un fenomen perceptual, un construct mental, o activitate imaginară, o „ficțiune utilă” (în sensul lui Veihinger, 1935). O varietate standard obiectivă nu există; există doar impresia colectivă (nu neapărat suma tuturor impresiilor individuale dintro comunitate) că o asemenea varietate ar exista. Odată apărută, această impresie tinde să se autoverifice: vorbitorii sînt orientați de propria lor credință în existența standardelor înspre utilizarea standardului în care cred.

(c). Înclin în mare măsură spre poziția (b), dar în această lucrare intenționez să analizez și să definesc o a treia perspectivă—cea potrivit căreia o limbă standard este atît o limbă (o varietate, o sub-varietate etc.) cît şi un standard.

Se conturează două aspecte legate de ea (Moschonas, 2005a,b):

Mai întîi, că o varietate standard este supusă unui proces continuu de standardizare, de-standardizare sau re-standardizare-în ciuda faptului că vorbitorii unei limbi pot să nu fie conștienți de desfăşurarea acestui proces transformator, cum, de altfel, s-ar putea să nu fie nici aceia dintre ei care sînt lingviști. $\mathrm{Cu}$ toate că, ideologic, sînt considerate a fi stabile, rezistente, invariabile, „un întreg” uniform, varietăţile standard prezintă variații considerabile și sînt ele însele supuse schimbării. Relaţia dintre un standard și alte varietăți ale unei comunități lingvistice este, în consecință, una dinamică și se află într-un flux continuu.

Diviziunea muncii între varietăţi admite inclusiv rearanjări. După cum sublinia Fishman (1972, p. 19),

Note that not all languages have standard varieties. Note also, that where a standard variety does exist, it does not necessarily displace the nonstandard varieties from the linguistic repertoire of the speech community for functions that are distinct from but complementary to those of the standard variety. Note, additionally, that there may be several competing standard varieties in the same speech community. Note, finally, that hitherto nonstandard varieties may themselves undergo standardization, whereas hitherto standardized varieties may undergo destandardization as their speakers no longer view them as worthy of codification and cultivation. Standardization in not a property of any language per se, but a characteristic societal treatment of language, given sufficient societal diversity and need for symbolic elaboration.

[rom.: Rețineți că nu toate limbile au o varietate standard. Rețineți și că acolo unde există o varietate standard, aceasta nu înlătură din repertoriul lingvistic al comunității vorbitoare, în mod necesar, varietăţile non-standard în funcții care sînt distincte de, dar complementare cu acelea ale varietății standard. Rețineți în plus că în aceeași comunitate vorbitoare pot coexista mai multe varietăți standard. În fine, observați că așa cum varietățile non-standard pot trece printrun proces de standardizare, și varietăţile standard pot trece printr-un proces de de-standardizare în măsura în care vorbitorii lor nu le mai percep ca demne de codificare și de cultivare. Standardizarea nu reprezintă o proprietate a niciunei limbi, per se, ci un tratament caracteristic pe care societatea îl aplică asupra limbii, în condiții de suficientă diversitate socială și de nevoie acută de elaborare simbolică.]

Apoi, acest proces de continuă re-standardizare nu ar putea avea loc_nici măcar n-ar fi înțeles—fără apelul la anumite norme, fără motivațiile ideologice ale respectivelor norme și fără practicile metadiscursive prin care sînt propagate normele și ideologiile lingvistice. Există întotdeauna o reacție reciprocă între normele 
lingvistice și limbile standard. La fel, relația dintre o normă și o varietate standard trebuie înțeleasă ca fiind una dinamică. De fapt, o varietate standard poate „tinde” spre un standard sau spre ceea ce se crede că este o varietate standard; dar standardul poate fi de asemenea prescris de o normă înșelătoare, prost plasată ori ineficientă, care nu corespunde în realitate niciunei varietăți, așa cum se întîmplă deseori în situaţiile de diglosie, unde normele dominante (ale varietății culte) nu se potrivesc cu uzul comun (cu varietățile inferioare). De asemenea, se pot înregistra conflicte în interiorul normelor; să ne amintim că lucrările de referință ale lui Haugen (1966a,b) despre standardizare se ocupă tocmai de asemenea conflicte. În anumite comunități au loc puternice 'dezbateri lingvistice ideologice' (Blommaert, 1999), care par uneori să dureze o veșnicie, cum a fost în cazul „Chestiunii limbii grecești” (Mackridge, 2009; v. infra).

Prezentul studiu îşi propune să urmărească schimbările de la nivelul unei varietăți standard prin prisma schimbărilor de la nivelul normelor respectivei varietăți; și făcînd asta, să încerce de asemenea să răspundă la dubla întrebare dacă și în ce măsură normele lingvistice pot explica schimbările de la nivelul limbilor standard.

Varietatea pe care o am în vedere este Greaca Modernă Standard (mai departe, GMS). Pe parcursul următoarelor patru secțiuni, voi pune în evidență patru schimbări la nivelul normelor GMS, căutînd totodată schimbări paralele sau contradictorii la nivelul GMS însăşi.

1. Prima schimbare analizată—una inaugurală—implică planificarea. Să privim puțin „momentul” istoric în care normele lui Psycharis privitoare la GMS au fost înlocuite de cele ale lui Triantaphyllidis; adică momentul în care standardul „ortodox”, uniform, pur al variantei demotice — standardul „vernacular” —, elaborat de lingvistul și entuziastul Jannis Psycharis, a lăsat locul standardului „mixt” propus de un lingvist ceva mai temperat, Manolis Triantaphyllidis:

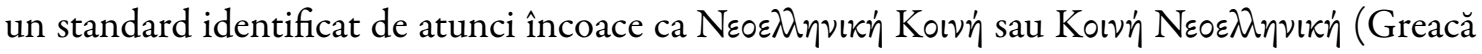
Modernă Standard, GMS).

Urmînd acestei schimbări majore în planificarea lingvistică, s-au manifestat alte trei schimbări în normele GMS. Toate trei au fost mediate, i.e. au fost inițiate în și/sau propagate prin tipar sau prin media electronice-în modalități care urmează a fi explicate mai jos. Primele două schimbări privesc mai ales norma scrisă, și vor fi examinate pornind de la exemple culese din mediul tipărit (presa grecească); ultima privește pronunția în GMS, și va fi analizată pe baza materialului oferit de radioul și televiziunea grecești. Cele trei schimbări, în ordine semi-cronologică, sînt:

2. O dată ce norma lui Triantaphyllidis și-a impus autoritatea, modelul indicațiilor corective asociat iniţial cu varianta demotică, un model gramatic/morfologic, a făcut loc unui model nou, frazeologic, care, din motive practice, este mai apt să impună de mult acceptatul deja standard „mixt”. Această schimbare majoră—o schimbare la nivelul normelor-este consemnată în îndreptarele de limbă și, de asemenea, în cele mai multe ziare și periodice care conțin rubrici de cultivare a limbii; avem de-a face, așadar, cu o schimbare mediată.

3. O dată ce și-a cîștigat această poziție, noua normă „mixtă” și-a pierdut treptat stigmatul ideologic vizavi de katharevousa, adică vizavi de adversitatea puristă și arhaizantă faţă de varianta demotică. În consecință, uzul morfologiei vernaculare vs arhaizante în cadrul noului standard „mixt” a încetat să mai diferențieze discursul public în privința ideologiei sale politice, a atitudinii culturale sau, mai important, a atitudinilor lingvistice. Nu era vorba doar de o schimbare la nivelul normelor; ci de o importantă schimbare la nivelul GMS înseși. Și a avut efect asupra mai multor variabile lingvistice de-a lungul întregului spectru politic al mijloacelor de comunicare în masă grecești-mai ales în ziare.

4. În sfîrșit, este clar că în mass-media audio-vizuale se desfăşoară la ora aceasta procese de desau re-standardizare (exemplificate de Politis, 2014, p. 210-306). Intrînd în cîteva din detaliile 
fenomenului, prezint în continuare una din aceste tendințe: prenazalizarea consoanelor oclusive sonore (Arvaniti \& Joseph, 2000). Voi arăta că lipsa de succes a acestei reguli prescriptive coincide cu un proces de restandardizare prin care nazalizarea a devenit, dintr-un obicei semiconştient cult, o marcă stilistică inconștientă.

Ca să distingem cele patru schimbări menționate anterior, am folosit un set de teste sociolingvistice simple, grupate în patru studii distincte dar interconectate:

1. Pentru a demonstra norma variaționistă, non-uniformă a lui Triantaphyllidis, am cuantificat și am aşezat în categorii toate referirile pe care Triantaphyllidis et al. (1978) le fac în cele mai importante gramatici ale GMS. Cuantificarea înlesnește realizarea unor comparații cu starea de fapt anterioară, cu norma gramaticală a lui Psycharis, și cu cea ulterioară, cu norma „descriptivă”, recentă, a gramaticilor limbii grecești moderne sau a îndreptarelor.

2. Pentru a detecta schimbările la nivelul normelor uzului-de la repertoriul „mixt” al lui Triantaphyllidis pînă la recomandările moderne privind uzul oferite la scară largă prin media—, am clasificat, cuantificat și comparat așa-numitele „instrucțiuni corective” (i.e. recomandări de uz) ce apar în presa scrisă.

3. Pentru a face dovada existenței conotațiilor ideologice (sau, la fel de bine, a absenței acestora) ale normei create, am testat mai multe variante morfologice înalte/inferioare din presa grecească, în încercarea de a vedea dacă ele se corelează cu profilul politic-ideologic al publicației respective (Kolia et al., 2013). A reieșit că variația morfologică și-a pierdut stigmatul ideologic; nu mai este dependentă de ideologia politică a publicațiilor.

4. În sfîrșit, ca dovadă a recentelor tendințe de restandardizare, prenazalizarea consoanelor oclusive sonore din vorbirea unor crainici de știri de radio și televiziune a fost corelată cu o variabilă independentă—,discursul oral citit (pre-scris)/liber”. A reieșit că crainicii radio-tv nu respectă regula prescriptivă privitoare la nazalizarea consoanelor oclusive sonore; s-a conturat un nou uz, în care nazalizarea este folosită ca marcă stilistică ce diferenţiază specii media și registre.

Cele patru modificări de la nivelul GMS și/sau de la nivelul varietăţii standard sînt examinate succesiv în secțiunile următoare. Ițele care probabil că le leagă vor fi reunite în secțiunea de Concluzii și discuții, unde voi elabora pe marginea jocului dintre practicile lingvistice specifice și normele lingvistice; voi oferi în final un cadru pentru cuantificarea efectelor prescriptivismului în interiorul paradigmei variaţioniste; şi voi lua în discuție texte importante dedicate efectelor prescriptivismului asupra schimbării lingvistice.

Elemente ale unei teorii mai cuprinzătoare care leagă normele lingvistice de limbile standard vor fi puse la dispoziție pe parcursul lucrării. Totuși, o schiță generală a acestei teorii trebuie expusă de la bunînceput, pentru a-i înlesni cititorului parcurgerea argumentării pe care o propunem. $\mathrm{O}$ voi numi teoria performativă a standardizării lingvistice. Pe scurt, afirmațiile metalingvistice (i.e., afirmații despre limbă de tipul celor prezente în lucrarea de față) nu constituie simple expresii ale credinței că așa stau lucrurile și nu altfel; caracterul lor este prescriptiv, iar forța lor ilocuționară este ce a actelor de vorbire (metalingvistice) directive, i.e. acte de vorbire care orientează vorbitorul unei anumite limbi spre un anumit comportament lingvistic. Prescriptivismul este rezumat în instrucțiuni corective explicite ori în recomandări privind uzul lingvistic. Întocmai ca în cazul altor acte verbale, instrucțiunile corective au mai degrabă un regim circumstanţial, decît unul supus condițiilor de adevăr: ele nu sînt adevărate sau false, ci sînt doar eficiente sau ineficiente, în circumstanțe particulare. Mai mult, pentru ca o instrucțiune corectivă să fie eficientă, ea trebuie să fie repetitivă. Media tipărite și digitale oferă platforme de unde instrucțiunile corective pot fi repetate și multiplicate, fie și numai prin exemple. Instrucțiunea corectivă are mai multe șanse de a ajunge la un public mai larg atunci cînd este emisă de către o instituție (Academia, de pildă) sau de către indivizi care se bucură de autoritate instituțională, sau de către profesioniști zeloși (corectorii). Corectivele au de 
asemenea nevoie de un mecanism de supraveghere și de control, care este pus în funcție în timpul anilor de formare școlară și care rămîne operative atît la nivel instituțional (corectarea ca practică profesională), cît și la nivel individual (auto-corectarea). In sfîrșit, pentru a avea succes, actele de vorbire corective trebuie să fie agreate de membrii comunității lingvistice; instrucțiunile corective trebuie să fie adoptate de către și într-un anumit mediu, într-un anumit registru ori în vederea unui anumite intenții stilistice. Utilizatorii limbii trebuie să se comporte din punct de vedere lingvistic în concordanţă cu modul în care au fost instruiți să se comporte; practica trebuie să respecte prevederile instrucției. Această ultimă 'componentă' nu se manifestă cu lejeritate. Este și greu de urmărit, din moment ce există întotdeauna posibilitatea ca instrucțiunile corective să nu fie respectate sau să fie executate defectuos, sau chiar să nu li se dea nicio atenție; ori să fie uitate de la o generație la alta. Teoria performativă a standardizării pe care o expunem aici nu este incompatibilă cu ipoteza că o limbă standard reprezintă o 'varietate' care trebuie re-învățată de fiecare generație de vorbitori în parte, sub îndrumarea instituțiilor, făcînd uz întotdeauna de un tip oarecare de mediere.

\section{Planificare}

Planificarea a ceea ce a ajuns să fie cunoscut ca Greacă Modernă Standard a trecut prin cel puțin două etape foarte distincte: prima se leagă de renumitul lingvist Jannis Psycharis (1824-1929) sau Jean Psychari, cum este cunoscut în Franța; cea de-a doua, de Manolis Triantaphyllidis (1883-1959). Impunătoarea personalitate a lui Psycharis marchează perioada „Sturm und Drang” a mișcării demoticiste; Triantaphyllidis, un lingvist nu atît de grandios, este asociat perioadei mai tîrzii, a „demoticismului de Stat” (denumirile și periodizările îi aparțin lui Triantaphyllidis, 1981, p. 119-144) ${ }^{2}$. Prima etapă este marcată de publicarea,

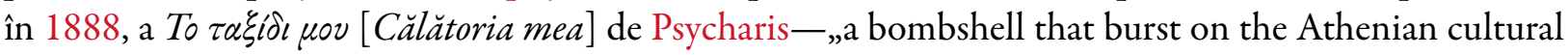
scene" [rom.: o bombă care a explodat pe scena culturală ateniană] (Mackridge, 2009, p. 215); cea de-a

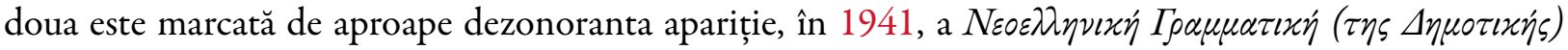
[Gramatica Limbii Grecești Moderne (Demotice)] de Triantaphyllidis et al..

Psycharis nu a scris o gramatică completă a variantei demotice. Cele trei volume ale „Marii” sale Gramatici a Limbii Grecești Moderne (Psycharis, 1929, 1935, 1937) abia reușesc să treacă de fonologia limbii grecești moderne. Era un pasionat observator al variației și schimbărilor din fonologia limbii grecești moderne $(\eta \chi 0 \alpha \lambda \lambda \alpha \xi \iota \alpha)$, iar gramatica sa conține numeroase observații despre forme variate, așa cum se întîmplă și cu multe alte scrieri ale sale, elaborate mai cu seamă în franceză (Psycharis, 1930, p. 58-114, 168-179, 189-251, 284-319, 237-238, 664-710, passim.). Psycharis rămîne cunoscut mai ales datorită lucrărilor sale grecești de popularizare, scrise pe un ton combativ și care au avut o considerabilă putere de influențare. Deși cele mai multe dintre aceste opere sînt declarat prescriptive, Psycharis a oferit exemple din varianta demotică prin felul său propriu de a scrie și de a utiliza limba, prin stilul său romanesc, și poate prin exagerările stilistice pe care le practica și pentru care a devenit celebru, Călătoria mea reprezentînd o culme în acest sens.

Discipolii au încercat să adere la norma închisă produsă de Psycharis, și la fel s-a întîmplat și în domeniul literaturii, unde s-a încercat decelarea unei norme pe baza textelor sale; v., e.g., Mandilaras (1972, p. 98-108). În opinia mea, asemenea sforțări de sistematizare ignoră grosolan variaţia considerabilă pe care o etalează opera lui Psycharis; totuși, asemenea demersuri nu rămîn fără valoare teoretică. Ele arată că, pînă și în munca oamenilor de știință, un standard se reduce la: o listă închisă și mai degrabă scurtă de „ce se face” și „ce nu se face”.

Pentru cei ce studiază greaca modernă, Mandilaras (1972, p. 98-108) „rescrie” standardul lui Psycharis, i.e. re-standardizează dogma maestrului, printr-un set finit de „corective” (afirmații prescriptive de tipul A $\rightarrow$ B, i.e. ,înlocuiește varianta A cu varianta B”):

\footnotetext{
${ }^{2}$ Triantaphyllidis ar fi fost de accord cu Geeraerts (2016) că modul în care Psycharis codifică greaca modernă corespunde „modelului romantic”, în timp ce viziunea lui însuși este una mai „rațională”. Dar asta ar însemna numai că distincția dintre modelul „romantic” și „rațional” este unul pre-teoretic.
} 


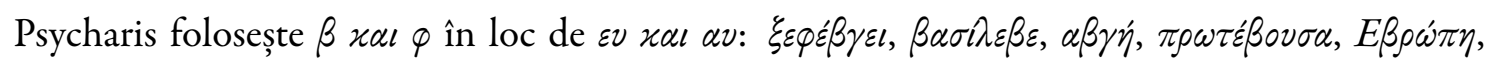

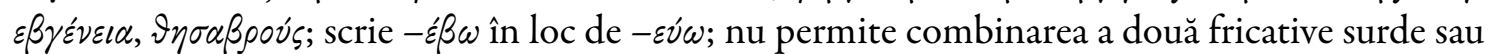
a două oclusive surde; asemenea combinări sînt transformate în fricativă + oclusivă: $\lambda \varepsilon \varphi \tau \varepsilon \rho ı \alpha ́$,

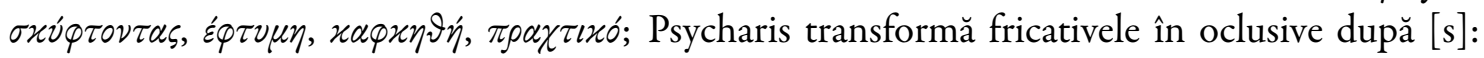

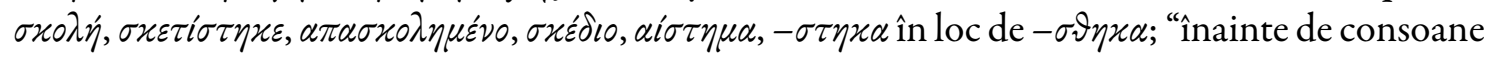

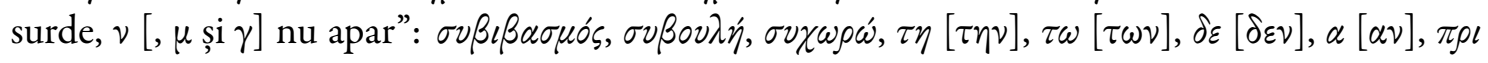
$[\pi \rho \nu] ; \lambda \rightarrow \rho / \ldots \phi: \alpha \delta \varepsilon \rho \varphi o ́ s ; \tau \rightarrow \theta / \ldots \rho: \alpha \nu \alpha \vartheta \rho \circ \phi \eta^{\prime} ; \gamma \rightarrow \varnothing / \ldots \mu: \pi \rho \alpha \dot{\mu} \mu \alpha ; \gamma \rightarrow \varnothing / V_{\perp} \mathrm{V}: \lambda \varepsilon \dot{\varepsilon} \omega, \pi \dot{\alpha} \omega ;$

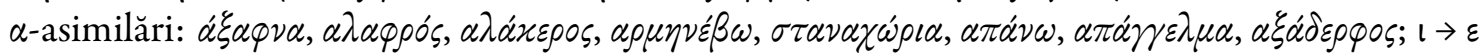

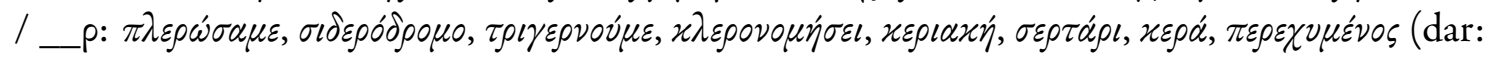

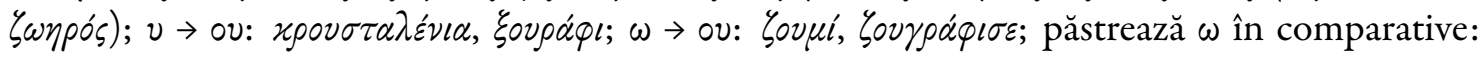
$\lambda \iota \gamma \omega \dot{\omega} \tau \rho \rho$; omite $\varepsilon$ și ı inițiale neaccentuate: $\varphi \eta \mu \varepsilon \rho i \delta \alpha, \pi \circ \mu \circ \nu \eta \dot{n}, \pi \circ \phi \varepsilon \dot{\rho} \nu \varepsilon \tau \alpha \iota$ (la fel, la augmentul

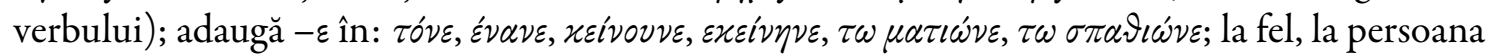

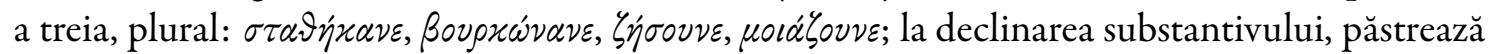
poziția accentului în concordanță cu cazul nom. dominant: থá $\lambda \alpha \sigma \sigma \alpha-\vartheta \alpha ́ \lambda \alpha \sigma \sigma \alpha \varsigma$ (în loc de

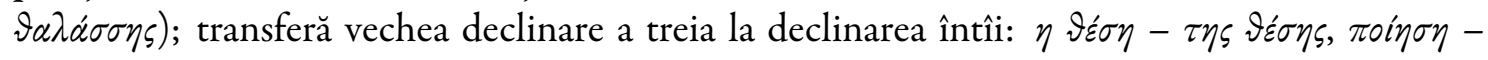

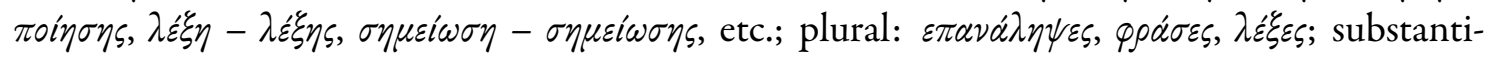
vele masculine și feminine terminate în consoană sînt declinate după regulile declinării întîi:

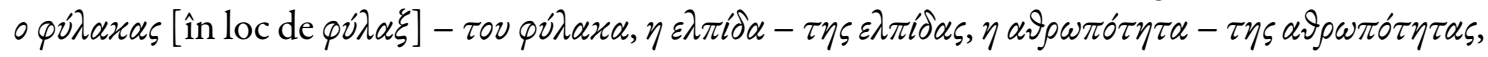

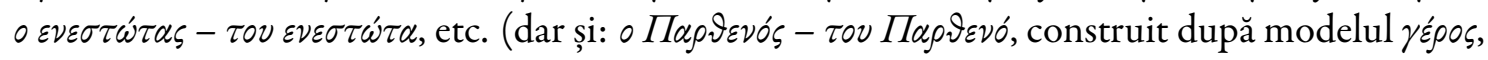

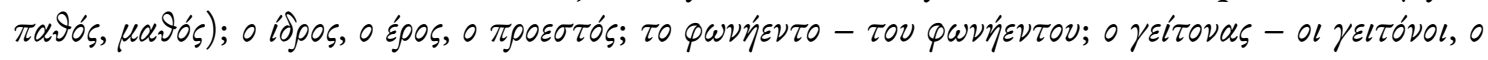

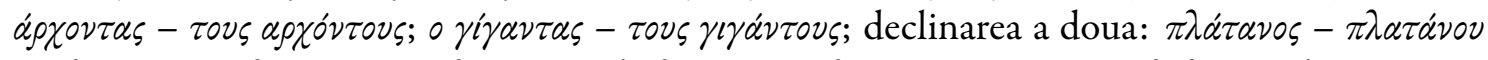

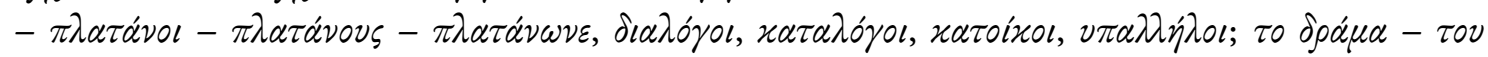

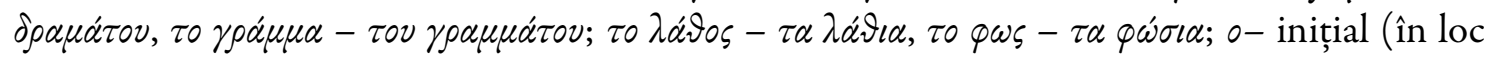
de $\omega-$ ), chiar și la timpurile de trecut; toate formele verbale contrase după cele terminate în - $\alpha \omega \omega$ :

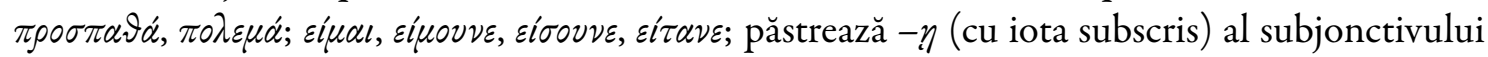

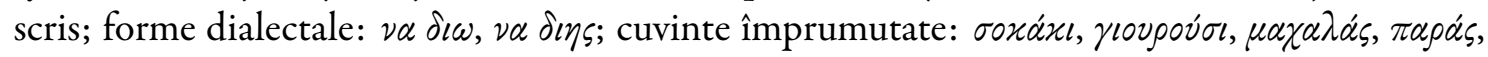

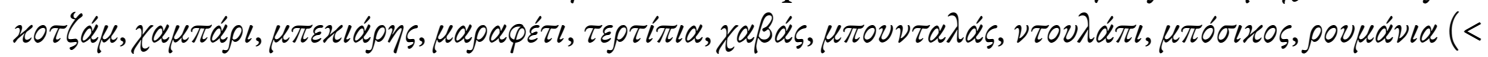

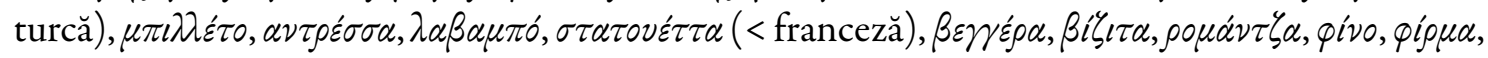
$\mu \circ \tau i \beta 0, \pi 0 \rho \sigma \varepsilon \lambda \dot{\alpha} \nu \eta, \tau \sigma \iota x o \lambda \alpha \dot{\tau} \alpha, \mu \pi \dot{\alpha} \nu \tau \alpha$ (< italiană), etc.; creații lingvsitice: $\alpha \pi \alpha \nu \omega \sigma i \alpha, \alpha \omega \rho \iota 0 \lambda \alpha \lambda \iota \dot{\alpha}$,

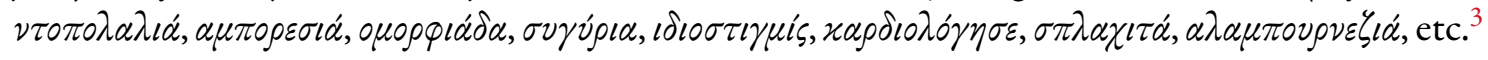

Lista de mai sus rezumă felul în care Mandilaras rezumă norma lui Psycharis. Putem observa anacronismul lui Mandilaras în descrierea normei lui Psycharis: în cazul mai tuturor „regulilor” de tipul $A \rightarrow B$, e.g. $\lambda \rightarrow$ $\rho / \ldots \phi: \alpha \delta \varepsilon \rho \varphi o ́ s$, A pare a fi o variantă care a reprezentat standardul, dar pe care Psycharis nu ales-o, sau care a devenit standardul în ciuda a ceea ce a ales Psycharis. Mandilaras nu spune pur și simplu: „dintre variantele existente, acestea sînt cele pentru care a optat Psycharis”, i.e. variantele B; Mandilaras lasă să se înțeleagă că „acele alte variante, A, sînt cele pentru care ar fi trebuit să opteze”, pentru că acelea sînt cele care erau sau aveau să devină standard—în ciuda preferințelor personale ale lui Psycharis. Prezentarea în această manieră a normei lui Psycharis nu este doar anacronică; este ea însăși normativă: sugerează că Psycharis ar fi trebuit să aibă alte opțiuni, că nu ar fi trebuit să facă alegerile pe care le-a făcut.

Mandilaras presupune de asemenea că la ora aceea exista o listă specială cu ce e corect și ce nu e corect, o normă la care Psycharis a aderat fără echivoc. Adevărul este că, pe măsură ce Psycharis continua să-și elaboreze propriul stil, a oscilat de mai multe ori în favoarea unor variante diferite, urmînd „reguli” diferite în etape diferite ale operei sale. Horrocks (2010, p. 448-449, citîndu-l pe Mackridge, 1988) comentează o situație în care se poate vedea schimbarea la nivelul normelor, un exemplu care, paradoxal, marchează data de naștere a standardului lui Psycharis, dacă acceptăm că ea coincide cu publicarea Călătoriei mele:

It is important to note [...] that changes were made between the first edition of My Journey in

\footnotetext{
${ }^{3}$ Reținem, în treacăt, că în ciuda a ceea ce se crede îndeobște, Psycharis înclina spre uzul împrumuturilor interne, i.e. adaptarea unor cuvinte din greaca veche la limba modern.
} 
1888 and the second in 1905. Psycharis took great pride in his Constantinopolitan connections, and the language of his youth at first took precedence in his writing, leading to the use of many now non-standard features in the first edition. By the time of the second edition, however, his conception of demotic had changed in the face of criticism of his usage.

[rom.: Este important să reținem [...] că între prima ediție a Călătoriei mele, din 1888, și cea de-a doua, din 1905, există diferențe. Psycharis se mîndrea mult cu legăturile sale la Constantinopol, iar limba din tinerețe i-a dominat la început scrisul, ceea ce a dus la întrebuințarea în prima ediție a numeroase forme care astăzi nu mai reprezintă standardul. În momentul elaborării celei de-a doua ediții, concepția sa despre varianta demotică se schimbase, ca reacție la criticile ce-i fuseseră aduse.]

Horrocks (2010, p. 449-451) menționează apoi destul de multe constantinopolitanisme fonologice, morfologice și sintactice pe care Psucharis le-a abandonat mai tîrziu. Meticuloasa comparație între cele două ediții ale Călătoriei mele făcută de Balomenou (2012) relevă un total de 910 schimbări intenţionate, cele mai multe find morfofonologice; numai cîteva reprezintă înlocuiri ale unor forme regionale, fie ele constantinopolitanisme sau de alt tip, în timp ce alte regionalisme apar în ediția a doua. Cele mai importante schimbări din ediția 1905 (judecînd după numărul ocurențelor) sînt însă, după Balomenou (2012), următoarele:

terminațiile în -n\# sînt înlocuite de cele în -ne\# (în spiritul preferinței generale a lui Psycharis's pentru terminaţiile în silabă deschisă), fapt ce afectează multe paradigme ale declinărilor, precum

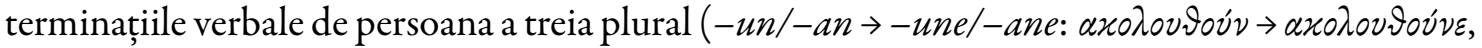
$\tau \rho \alpha \beta o v \sigma \alpha \nu \rightarrow \tau \rho \alpha \beta \sigma v \sigma \alpha \nu \varepsilon$, cu o schimbare concomitentă în privința poziției augmentului, de la

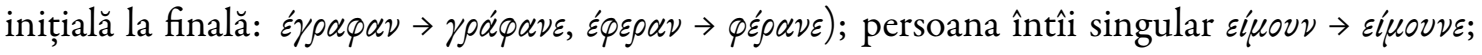
de asemenea, genitivul plural al substantivelor $(\tau \omega \delta \alpha \sigma x \alpha \dot{\lambda} \omega \nu \rightarrow \tau \omega \delta \alpha \sigma x \alpha \dot{\lambda} \omega \nu \varepsilon)$ și al pronumelor $(\tau \dot{\sigma} \sigma \omega \nu \rightarrow \tau \dot{\sigma} \sigma \omega \nu \varepsilon)$. Marca perfectivă $-k s-$ se simplifică la $-s-\left(\rho \omega \tau \dot{\eta}^{\prime} \xi \omega \rightarrow \rho \omega \tau \dot{\eta}^{\prime} \sigma \omega, \sigma \pi \circ \nu \delta \dot{\alpha} \xi o \nu \mu \varepsilon \rightarrow\right.$ $\sigma \pi 0 v \delta \dot{\alpha} \sigma o v \mu \varepsilon)$. Particula $\pi \circ v$ este înlocuită fie de conjuncția $\pi \omega \zeta$ sau de o formă relativă $(\pi \circ v \rightarrow$ $\pi \omega \varsigma / o ́ \pi 0 v)$. FÎn sfîrșit, și, totodată, mai puțin important, cliticele pronominale de acuzativ, obişnuite în dialectul constantinopolitan, sînt înlocuite cu forme de genitiv, obişnuite în dialectele sudice $(\mu \varepsilon \rightarrow \mu \circ v, \sigma \varepsilon \rightarrow \sigma \circ v)$.

Toate modificările de tipul $A \rightarrow B$, „varianta B înlocuiește varianta $A$ ” reprezintă exemple de ceea ce mai tîrziu vom numi: „corective”, i.e. acte conștiente de corectare a vorbirii personale sau a altora. Sînt de părere că modificările operate de Psycharis între cele două ediții („,corectivele” sale) susțin următoarele afirmații preliminare: în primul rînd, este cît se poate de evident că asemenea variații trebuie să existe înainte de elaborarea unui standard; în al doilea rînd, o oarecare variație trebuie să existe-inevitabil chiar-în interiorul unui standard; și în al treilea rînd, variația în interiorul unui standard este, cel puțin pînă la un punct, supusă capriciului, arbitrarităţii, nemotivării (immotivé, în original). Pornind de la aceste aserțiuni preliminare, se poate deduce că raționalizarea unui standard reprezintă o etapă mai tîrzie în evoluția respectivului standard; totodată, recunoașterea retrospectivă a variantelor care au devenit standard într-o etapă precedentă nu poate fi decît anacronică. Constantinolopitanismele lui Psycharis au fost abandonate în bună măsură cu ocazia publicării ediției a doua a Călătoriei mele. Psycharis nu era însă interesat în mod deosebit de idiomul din Constantinopol per se; după cum o arată enumerarea de mai sus, preocuparea lui viza mai degrabă prescrierea uzului unor variante care puteau pretinde să devină standardul. Unele dintre

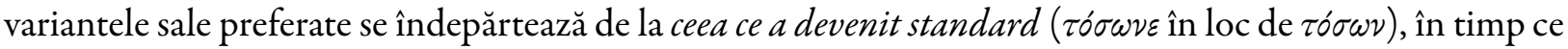
altele au devenit parte integrantă a standardului ( $\rho \omega \tau \eta^{\prime} \sigma \omega$ în loc de $\left.\rho \omega \tau \dot{\eta}^{\prime} \xi \omega\right)$.

Nu s-au scris studii despre variația lingvistică din proza lui Psycharis, dar se observă cu ușurință că stilul său este oral și ludic, chiar dacă unei urechi moderne îi poate părea „artificial” (Chrissomali-Henrich, 2005, p. 202-203). Standardul său literar, tocmai pentru că este idiosincretic, este departe de a fi uniform. În 
mod ciudat, nu se conformează niciunuia dintre standardele în care l-au vîrît unii și alții, după cum o de-

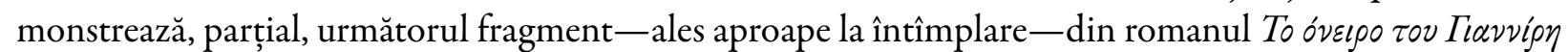
[rom.: Visul lui Janniri] (Psycharis, 1897, p. 161-162):

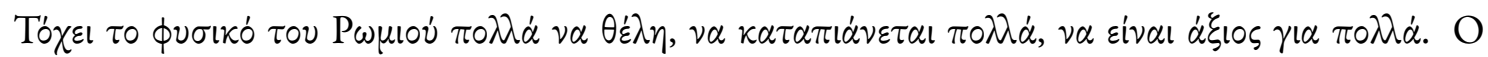

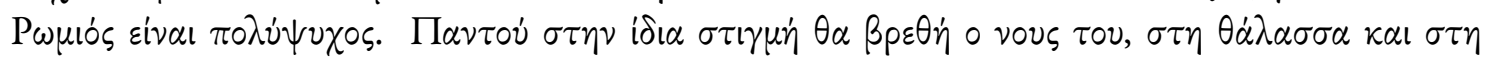

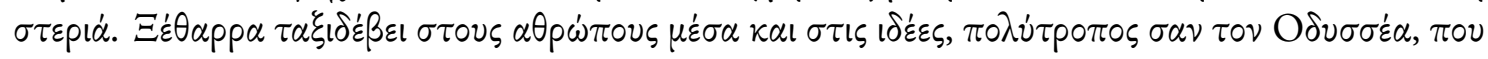

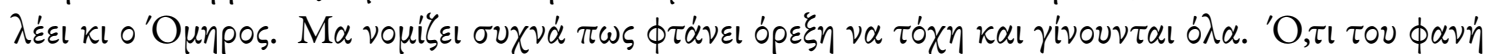

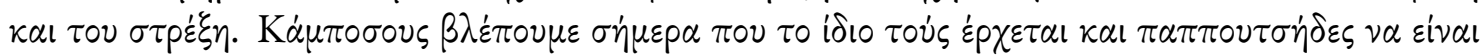

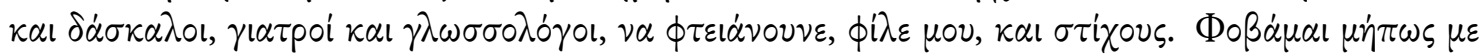

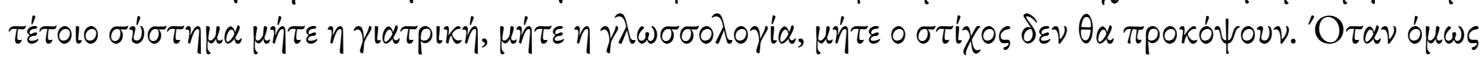

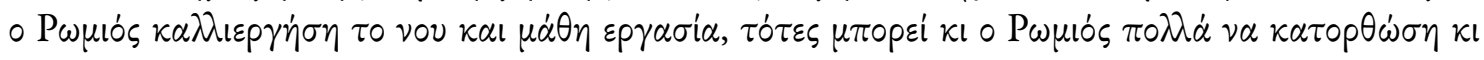

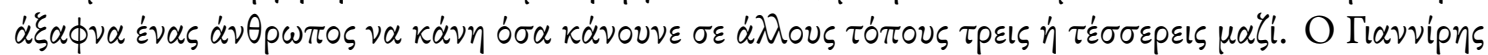

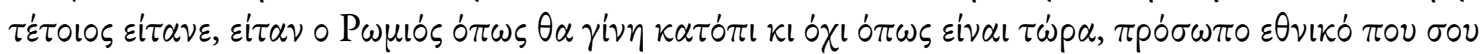

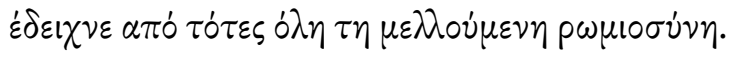

[rom.: Grecul este într-o continuă căutare, este permanent ocupat, este competent în toate. Grecul are multe suflete. Gîndurile îi hoinăresc în acelaţi timp peste tot, pe mare și pe uscat. Călătorește prin oameni și prin idei, neînfricat—un om al frămîntărilor, ca Ulise, cum ar spune Homer. Crede că unde este voință, acolo este și înfăptuire. Își îngăduie să fie asta ori cealaltă. Vedem pe cineva care-și spune și pantofar, și profesor; și doctor, și lingvist; iar unii scriu și versuri, prietene. Cu mentalitatea aceasta, mă tem că nici medicina, nici lingvistica, nici poezia nu vor ajunge prea departe. Dar cînd grecul se cultivă și cînd își pune în cap să se facă ceva anume, atunci poate realiza de unul singur mult mai mult decît ar reuși să facă doi sau trei oameni dintr-o altă țară. Janniris era un asemenea tip, era grecul ce putea deveni, nu grecul ce este la un moment dat, era individul prin care se etala întreg viitorul nației.]

Probabil că nu avem de-a face aici cu marea literatură. Personajul, Janniris, este intens ideologizat: asupra lui este proiectat stereotipul pe care Psycharis îl cultiva despre națiunea grecească (și despre omenire). Poate că personajul era construit pe modelul autorului însuși („Janniris” ar putea foarte bine fi un alter ego al lui „Jannis Psycharis”). Dar limba este fluentă. Cele cîteva devieri de la ortografia actuală sînt nesemnificative; terminația de subjonctiv $-\eta$ a fost păstrată și în scrierile de mai tîrziu; personal, găsesc ortografierea $\varepsilon i \nu \alpha \iota-\varepsilon i \tau \alpha \nu \varepsilon(\varepsilon)$ mult mai sistematică decît $\varepsilon i \nu \alpha l-\eta \dot{\tau} \tau \alpha \nu(\varepsilon)$. Nu întîlnim acele „extremisme” de care Psycharis a fost atît de des acuzat. Stilul este oral, chiar conversațional—sau aşa se vrea a fi. Există

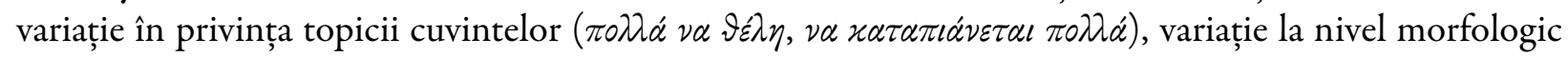

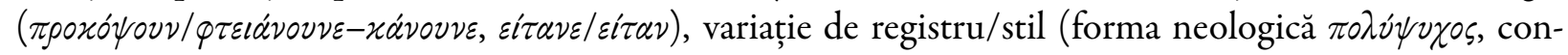
struită după forma homerică $\pi 0 \lambda v i \tau o \pi \circ \varsigma$-amîndouă coexistînd cu elemente din vocabularul comun, e.g. $\pi \alpha \pi 0 v \tau \sigma \dot{n} \delta \varepsilon \zeta$ „pantofari”, și cu variante „demotice”, e.g. $\tau o ́ \tau \varepsilon \zeta)$. Se creează impresia că Psycharis urmărește crearea unui standard scris care să îi permită să fie oral. Un romancier slab, poate; totuşi, scriitor competent, Psycharis a standardizat limba prin exemplu, prin propriile sale scrieri, nu doar interzicînd uzul anumitor forme, ci și exploatînd unele variații. Este adevărat, Psycharis ar fi putut visa „a single language variety $[. .$.$] for all purposes, both oral and written, allowing little leeway for variation according to lingu-$ istic register" [rom.: o singură variantă lingvistică [...] bună la toate, și orală, și scrisă, care să îngăduie prea puțină variație față de registrul lingvistic] (Mackridge, 2009, p. 226); numai că el însuşi nu a scris într-o asemenea manieră uniformă.

Ideea că Psycharis a urmat un standard foarte strict și uniform s-a născut probabil din lucrările oponenților lui. Și a fost perpetuată de o relevantă istoriografie, care a notat deseori că Psycharis, influențat de sistematicele „legi naturale” ale neogramaticilor, nu tolera niciun fel de excepție de la regulile sale (Kriaras, 1981, p. 182-183; Babiniotis, 2011, p.432-435; cf. Mackridge, 2009, p. 215-228). Catalogarea limbii lui Psycharis ca „ortodoxă” și „dogmatică”, „artificială”, „puristă”, ,inflexibilă”, ,ultra-demoticizată” 


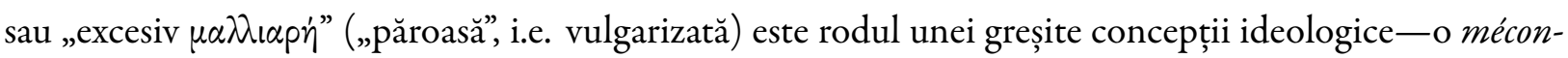
naissance-hrănite de opozanți și reproduse ca atare de istorici. Vom reveni asupra acestei chestiuni a uniformității în cadrul secțiunii de Concluzii și discuții, unde vom prezenta și cîteva dintre problemele pe care standardizarea prin propriul exemplu le ridică în legătură cu ceea ce propun eu ca teorie performativă a standardizării limbii.

Manolis Triantaphyllidis nu era unul dintre oponenții lui Psycharis; dar asta nu înseamnă că Psycharis și lar fi dorit ca aliat. Vorbea despre Triantaphyllidis cu dispreț; îl numea „naiv” ( $\alpha \gamma \alpha \theta$ ós). Îl considera avocat al „compromisului” cu katharevousa, varianta înaltă arhaică. L-a acuzat că „flirtează” cu katharevousa și a încercat să-i demaște normele „mixte” (Psycharis, 1924). Avea perfectă dreptate. Triantaphyllidis însuşi afirmase că era necesar un compromis cu katharevousa, cu toate că și el a optat pentru o mai „uniformă” 'demotică de școală’ (cf. Mackridge, 2009, p. 228). Toate acestea erau istorie, și chiar în momentul desfășurării lor. Privind în urmă, singurul lucru cu adevărat important este că standardul propus de Psycharis a eșuat; cel al lui Triantaphyllidis s-a impus.

Cea mai importantă lucrare de referință pentru varianta demotică, Gramatica Greacă Modernă (Demotică) de Triantaphyllidis et al., a fost publicată în 1941, o perioadă istorică dificilă. Triantaphyllidis prezida comitetul căruia dictatorul Ioannis Metaxas îi ceruse alcătuirea unei gramatici a limbii grecești moderne bazate pe norma demotică; s-a stabilit însă unanim că gramatica publicată în 1941 este de fapt opera unui singur om, Traintaphillidis.

Noua gramatică a marcat o schimbare în privința normelor demoticei. Psycharis propusese o modernizare radicală a gramaticii limbii. Ar fi trebuit să urmeze aspectul sistematic al varietăţilor orale, să includă variante rurale și să asigure adaptarea morfologică a vocabularului cult sau arhaic. Norma aceasta apărea în contrast puternic cu normele variantei înalte, scrise, katharevousa (în fapt, nu a existat niciodată o singură varietate de katharevousa, așa cum nu a existat niciodată o singură varietate de demotic, ele variind de la autor la autor). Spre deosebire de norma lui Psycharis, norma lui Triantaphyllidis se baza pe ceea ce a fost considerat a fi de atunci încolo varietatea lingvistică urbană a clasei de mijloc educate (cf. Mackridge, 1985, p. vi). Această normă nouă era mult mai tolerantă față de formele culte, nu respingea arhaismele neadaptate sau străinismele. Niciunul dintre standarde (sau, mai bine spus, niciuna dintre varietăți), nici cel al lui Psycharis, nici cel al lui Triantaphyllidis, nu era absolut pur; numai că cel al lui Triantaphyllidis era în mod deschis astfel. Triantaphyllidis nu doar a elaborat pe marginea poziției lui Psycharis. Ci a crezut că un ,amestec” controlat de demotic cu varianta înaltă va facilita acceptarea celei dintîi, va provoca o deideologizare a variantei demotice, făcînd-o mai ușor de acceptat de către Stat. O dată adoptată de către Stat, s-ar fi încheiat perena „Chestiune a limbii grecești” (Frangoudaki, 1977, p. 104-116; Moschonas, 2010). De altfel, Triantaphyllidis prefera să-și numească gramatica, „Gramatica de Stat”.

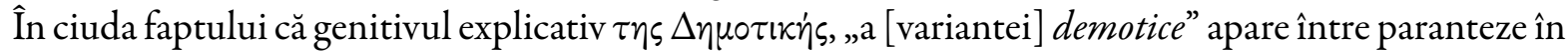
titlul acestei gramatici de stat, probabil că Triantaphyllidis ar fi preferat formula „koine greacă modernă”i.e. ceea ce astăzi numim greacă modernă standard. Pe scurt, formula lui de standardizare este aceasta:

Koine $[$ greacă modernă standard $]=$ Popular/jos [Demotic $]+$ Cult/înalt $[$ Katharevousa $]$ (în funcție de necesități).

Triantaphyllidis et al. (1978) au propus un standard departe de a fi uniform. Gramatica se prezenta în același timp ca prescriptivă și ca variaționistă; v. Prefața lui Triantaphyllidis la Gramatică, mai ales $\kappa \alpha^{\prime}$, $\left.\kappa \beta^{\prime}-\kappa \delta^{\prime}\right)$. Fig. 1 reproduce pagina 102 a Gramaticii, unde se discută derivarea și unde sînt expuse cîteva variante (katharevousa/demotic). Termenii pe care Triantaphyllidis îi folosește în legătură cu aceste vari-

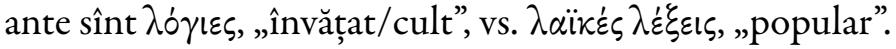

Pagina 102 se află în partea a doua a Gramaticii, numită Cuvintele, aproape în întregime rezervată variației lexicale. Trebuie să subliniem faptul că atitudinea lui Triantaphyllidis față de străinisme nu era puristă (în legătură cu lucrările sale timpurii despre împrumut, v. Papanastasiou, 2011). Extrasele de la 


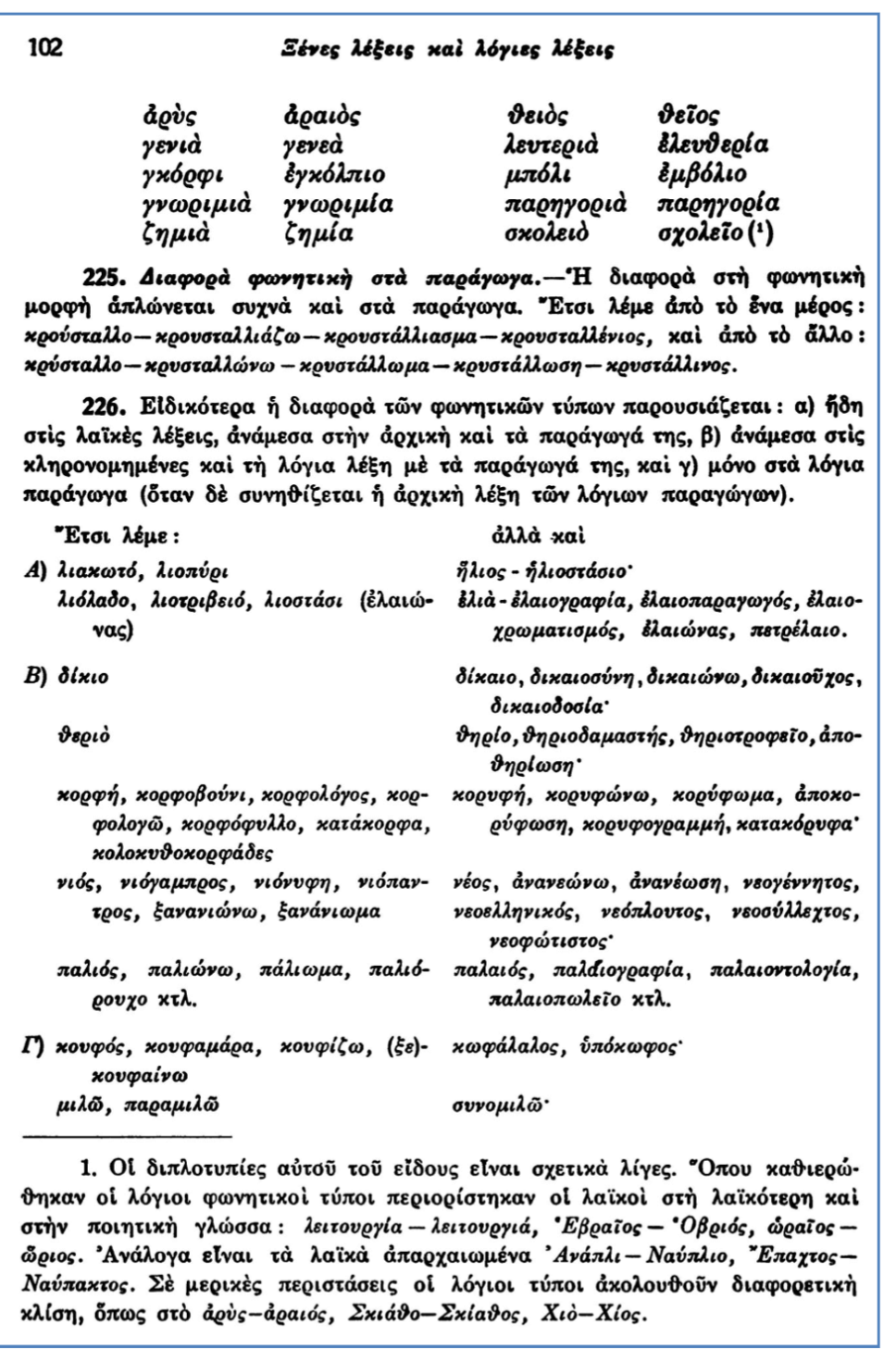

Figura 1: Pagina 102 din Triantaphyllidis et al. (1978).

paginile 231 și 232, prezentate în Fig. 2, aparțin părții a treia a Gramaticii, în care este prezentată morfologia limbii grecești moderne. În Fig. 2 constatăm o modalitate mult mai obișnuită de abordare a variației: mai întîi este prezentată o paradigmă a declinării, iar dedesubt, după o serie de exemple (în căsuţa gri), apar posibilele variante sau „excepțiile”. De notat că forma de vocativ $\pi \dot{\alpha} \tau \varepsilon \rho$ este folosită și la nominativ de mulți vorbitori ai limbii grecești moderne (ca în $o \pi \alpha ́ \tau \varepsilon \rho ~ \varphi \alpha \mu \iota \lambda \iota \varsigma_{\varsigma}<$ Lat. pater familias, „tatăl familiei”). La p. 232, Triantaphyllidis prezintă pur și simplu aceste forme ca variante $(o \pi \alpha \tau \xi \rho \rho \varsigma / \pi \alpha \tau \eta \dot{\rho} \rho / \pi \alpha \dot{\tau} \varepsilon \rho)$, deși, după normele limbii grecești vechi sau ale katharevousa, sau, de fapt, după standardele actuale, nominativul $\pi \dot{\alpha} \tau \varepsilon \rho$ ar fi trebuit tratat ca greșeală stridentă.

Parantezele sînt folosite în Gramatica lui Triantaphyllidis ca mijloc tipografic de indicare a variației; de obicei, formele care apar între paranteze sînt cele mai puțin preferate:

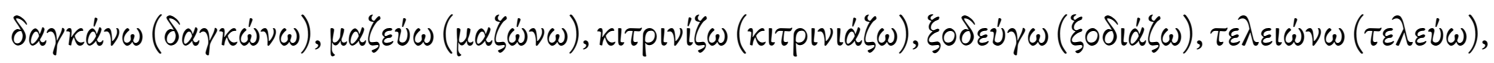

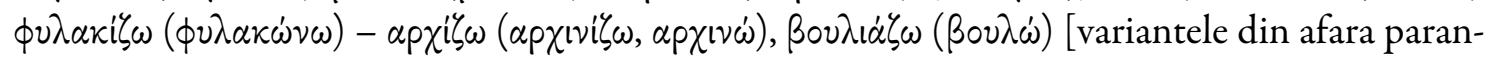
tezelor „sînt preferate în proză”] (Triantaphyllidis et al., 1978, p. 349).

Uneori însă, același mijloc tipografic pare să indice variația necondiționată, liberă:

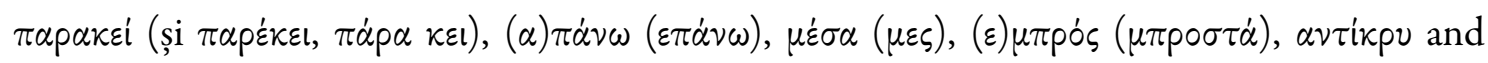




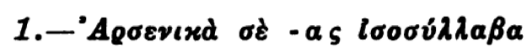

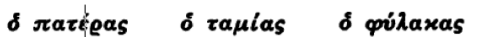

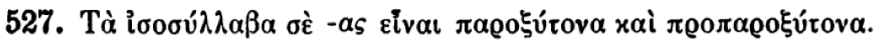

\begin{tabular}{|c|c|c|c|c|c|c|}
\hline \multicolumn{7}{|c|}{ Evixòs } \\
\hline${ }^{\circ} \mathrm{O} v \boldsymbol{\mu}$. & $\delta$ & $\pi \alpha \tau \hat{\varepsilon} \varrho \alpha \varsigma$ & $\delta$ & $\tau \alpha \mu i \alpha_{S}$ & $\delta$ & $\varphi v ́ \lambda \alpha x a s$ \\
\hline$\Gamma \varepsilon v$ & $\tau o \tilde{v}$ & $\pi \alpha \tau \varepsilon ́ \varrho \alpha$ & $\tau o \tilde{v}$ & $\tau \alpha \mu i \alpha$ & $\tau o \tilde{v}$ & qúlaxa \\
\hline Air. & $\tau \dot{o v}$ & 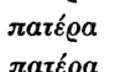 & $\tau \grave{\nu} v$ & 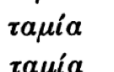 & tò & qv́laxa \\
\hline \multicolumn{7}{|c|}{$\Pi \lambda \eta \theta v v v \tau \imath$ ròs } \\
\hline${ }^{\circ} \mathrm{O} о \mu$. & oi & $\pi \alpha \tau \varepsilon \varrho \varepsilon \varsigma$ & of & $\tau \alpha \mu i \varepsilon \varsigma$ & oi & qúlaxes \\
\hline$\Gamma \varepsilon v$. & $\tau \tilde{\omega} \boldsymbol{\nu}$ & $\pi \alpha \tau \varepsilon \varrho \omega \nu$ & $\tau \tilde{\boldsymbol{\omega}} \boldsymbol{\nu}$ & $\tau \alpha \mu \iota \tilde{\omega} \nu$ & $\tau \tilde{\omega} \boldsymbol{\nu}$ & 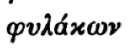 \\
\hline Aitr. & rov̀s & $\pi \alpha \tau \varepsilon ́ \varrho \varepsilon \varsigma$ & toùs & $\tau \alpha \mu i \varepsilon s$ & zoùs & qúdaxes \\
\hline $\mathrm{K} \lambda \eta \tau$. & & $\pi \alpha \tau \dot{\varepsilon} \varrho \varepsilon \varsigma$ & & $\tau \alpha \mu i \varepsilon s$ & & $\varphi \dot{\lambda} \lambda \alpha x \varepsilon s$ \\
\hline
\end{tabular}

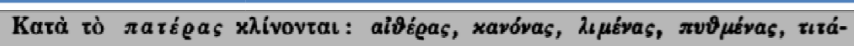

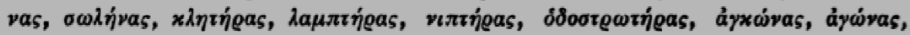

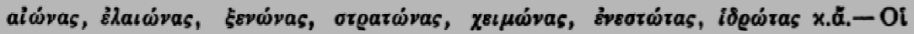

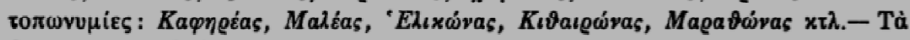

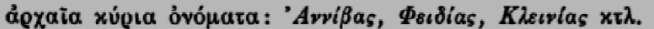

Katà rò ra

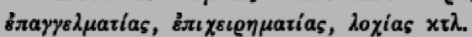

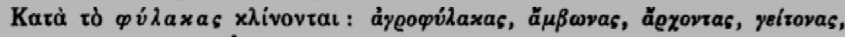

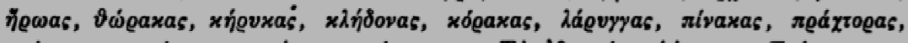

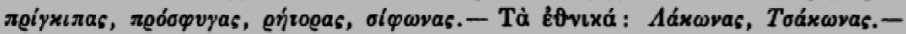

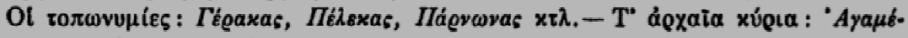

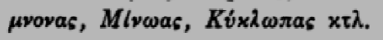

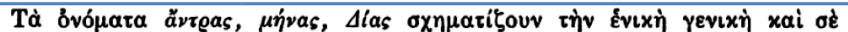

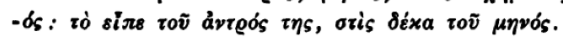

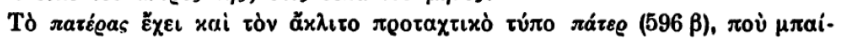

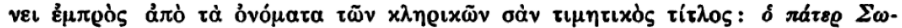

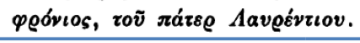

Figura 2: Fragmente din p. 231 și 232 din Triantaphyllidis et al. (1978): o paradigmă de declinare, urmată de exemple și variante.

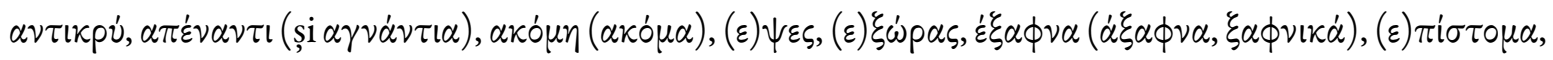

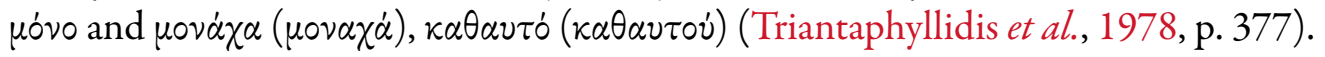

\section{Studiul 1: Corectivele din Gramatica lui Triantaphyllidis}

Cît de multă variație este, pînă la urmă, în Gramatica lui Triantaphyllidis? Și cît de multă variație este exclusă ori pur și simplu neluată în seamă? Pentru a răspunde la aceste întrebări cît se poate de precis, este nevoie de o modalitate exactă de măsurare a prescriptivismului—sau a absenței acestuia.

O asemenea modalitate este de a număra ceea ce în altă parte (Moschonas, 2005c, 2008) am numit „corective” (sau instrucțiuni corective). O corectivă poate fi definită ca act directiv în direcția de acomodare metalimbă - limbă . Există cel puțin două tipuri de corective: corectivele propriu-zise și permisive. În forma lor cea mai simplă, primele sînt alcătuite din trei componente: una prohibitivă ('nu se spune/nu

\footnotetext{
${ }^{4}$ „Direcție de acomodare” [engl. direction of fit; cf. fr. direction d'ajustement] este un criteriu de clasificare folosit de John Searle în capitolul A taxonomy of illocutionary acts (în Searle, 1979, p. 1-29). Potrivit lui Searle, există patru posibile direcții de acomodare ale actelor de vorbire (cuvintele) și stărilor de lucruri (lumea): a) cuvinte-la-lume, b) lume-la-cuvinte, c) amîndouă, d) niciuna. Directivele (comenzi, cereri etc.), în cadrul cărora corectivele putem spune că formează o subcategorie, prezintă o direcție de acomodare lume-la-cuvinte (Searle, 1979, p. 14). Desigur, taxonomia lui Searle este prea îngustă. Există cel puțin o categorie de acte de vorbire, anume corectivele (corective propriu-zise și permisive, deopotrivă), care par să prezinte o direcție de acomodare cuvinte-la-cuvinte (de la metalimbă la limbă). Dacă se acceptă că corectivele dețin forța directivelor și dacă se acceptă că realitățile despre limbă sînt realități despre lume, atunci și corectivelor ar trebui să li se recunoască direcția de acomodare lume-la-cuvinte, caracteristică directivelor. În opinia mea, aceasta este o problem teoretică fără importanță în discuția de față. Voi reveni însă asupra teoriei performative a corectivelor în secțiunea de Concluzii și discuții.
} 
se scrie X'); una normativă ('se spune/se scrie Y'); și una explicativă ('pentru că Z'). De pildă, următoarea construcție reprezintă o corectivă:

[trebuie să] spunem/scriem $\sigma \nu \beta ı ß \alpha \sigma \mu o ́ s ~[$ sivivazmos], „compromis” (Y)

în loc de $\sigma v \mu \beta ı \beta \alpha \sigma \mu o ́ s ~[s i m v i v a z m o s] ~(X)$,

deoarece fonologia noastră nu acceptă combinația [consoană nazală $]+[$ consoană fricativă $](Z)$ (Psycharis, 1888, p. 163 ff.; 1905, p. 155 ff.)

Și o permisivă este un act directiv în direcția de acomodare metalimbă - limbă. În forma lor cea mai simplă, permisivele sînt alcătuite tot din trei componente: una permisivă ('se spune/se scrie X, alături de Y'); una normativă, care de obicei exprimă o condiție legată de variația $\mathrm{X} / \mathrm{Y}$ (' $\mathrm{X}$ se folosește în situația $\mathrm{C}_{1}$; $\mathrm{Y}$ se folosește în situația $C_{2}$ '); și una explicativă opțională ('pentru că $Z$ '), care de obicei reiterează componenta normativă/condițională. De pildă, următoarea construcție reprezintă o permisivă:

se poate spune/scrie $\delta \alpha \gamma \kappa \omega \dot{\nu} \omega \omega$, ,a mușca” (X),

dar $\delta \alpha \gamma \kappa \dot{\alpha} \nu \omega(\mathrm{Y})$

este de preferat în proză $\left(\mathrm{C}_{2}\right)$.

(Triantaphyllidis et al., 1978, p. 349)

Permisivele de acest tip au de regulă caracter funcțional; fiecare variantă este restricționată la un anumit domeniu, i se atribuie o funcție sau se presupune că are o anumită încărcătură stilistică. Pot fi formulate și permisive de variație liberă, de tipul:

$\mathrm{X} \mathrm{sau} /$ și Y.

Desigur, asemenea permisive, afirmînd o variație liberă, necondiționată, nu sînt ușor de formulat în gramaticile tradiționale (deși am putut vedea cîteva exemple la Triantaphyllidis; v. de asemenea variantele sale „paralele” și „echivalente”). Raritatea permisivelor necondiționate nu trebuie să ne mire. Tendința de a funcționaliza variația este comună multora; apare ca un „instinct natural”. Se presupune că gramaticile descriptive tocmai asta fac: explică variația prin distribuirea a diferite funcții diferitelor variante, conform doctrinei „simetriei formă - funcție”, care atribuie fiecărei forme o funcție distinctă (Poplack, van Herk \& Dawn, 2002, p. 88-89; Poplack \& Dion, 2009, p. 557; Poplack, Lealess \& Dion, 2013, p. 189; Anderwald, 2016, p. 83, urmîndu-l pe Zwicky, 2009, denumește această doctrină „principiul unei singure căi corecte”). O doctrină întemeietoare similară în sociolingvistică proclamă că „nu există variante libere”. Pentru ambele doctrine voi folosi expresia eroarea formă - funcție.

Și permisivele cad victimă acestei erori. În mod curent, chiar dacă nu stipulează explicit că o variantă este preferabilă alteia, permisivele pot sugera, mai cu seamă în gramaticile tradiționale, că una sau alta dintre variante este de preferat: permisivele sînt implicit condiționale. Pe lîngă asta, o construcție permisivă poate fi cu uşurință transformată într-una corectivă, menţionînd pur și simplu că condiția necesară pentru ca varianta să se manifeste a fost violată. De exemplu, în locul permisivei funcționale din Gramatica lui Triantaphyllidis, citată mai sus, poate fi formulată următoarea corectivă:

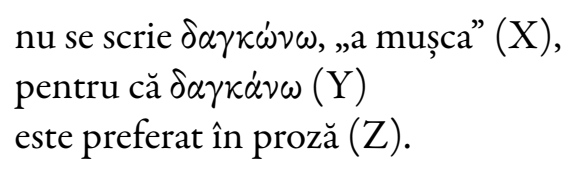

Corectiva este deja implicită în permisivă, și de aceea nu voi ezita să folosesc atît pentru corectivele propriuzise, cît și pentru permisive denumirea generică de corective.

Am văzut pînă acum exemple de corective (fie propriu-zise, fie permisive) avînd formă obişnuită (sau o formă reglementată, pentru uşurătatea înțelegerii). De fapt, în gramaticile și îndreptarele de limbă corectivele apar rareori în forma regulată, completă (Moschonas \& Spitzmüller, 2010, p. 23-26). Corectivele 
pot fi eliptice (lipsește o parte, i.e. X și/sau Y nu sînt specificate ori nu este prezent Z). Lipsa unei părți explicative este un fapt comun: în multe cazuri nu se oferă nicio justificare pentru o corectivă; sau se întîmplă ca explicativa să ofere ceva ce se dovedește a fi o justificare circulară („,nu se spune sau se scrie X, deoarece nu este indicat—corect, frumos, potrivit, bine exprimat etc.—să se spună sau să se scrie X”); sau se invocă o mai generală corectivă, faţă de care cea în discuție nu reprezintă decît un caz particular. În asemenea situații, trebuie să apelăm la analogia cu alte corective ori să avem în vedere corectivele similare cu care cea în discuție se asociază de obicei; sau am putea să sondăm un pic mai adînc în mentalitatea prescriptivă a unui text pentru a înțelege motivul preferinței stipulate în locul analizat. Corectivele diferă și în privința specificității lor. Putem distinge corective-tip (instrucțiuni generale) și corective-blazon (instrucțiuni specifice); din nou, o instrucțiune-blazon poate fi dată ca exemplu de instrucțiune-tip mai generală, i.e. ' $x_{1}, \ldots, x_{n}$ ar trebui evitate ca blazon pentru $X$ '; sau ' $y_{1}, \ldots, y_{m}$ ar trebui preferate ca blazon pentru Y'; sau o corectivă-blazon poate fi, pur și simplu, un exemplu subordonat unei „reguli” generale, i.e. unei instrucțiuni-tip generale. Permisivele pot fi, de asemenea, eliptice, tip sau blazon, după cum se observă din exemplele care urmează, extrase din Triantaphyllidis et al. (1978); le-am ales pentru că ilustrează diferențele dintre tipurile și formele corectivelor și/sau permisivelor ${ }^{5}$ :

Corective-tip: „varianta koine, forma comună a limbii $[\mathrm{Y}]$ trebuie redată; asta înseamnă două lucruri: fără arhaisme, i.e. forme culte $\left[\mathrm{X}_{1}\right]$, și fără dialectalisme [sau localisme: $\left.\delta \delta เ \omega \mu \alpha \tau \imath \sigma \mu o i\right]$, i.e. forme regionale $\left[\mathrm{X}_{2}\right]$ - cu excepția, desigur, a situațiilor cînd asemenea forme sînt esențiale limbii comune" (p. $\left.\eta^{\prime}\right)$

Corective-blazon: „unii spun greșit $\alpha \pi \circ-\theta \alpha \nu \alpha \tau i \zeta \zeta[X]$, 'imortaliza', în timp ce forma corectă este $\alpha \pi-\alpha \theta \alpha \nu \alpha \tau i \zeta \omega^{\prime \prime}[\mathrm{Y}]($ p. $154 \$ 342)$

Corective-tip/eliptice $(\mathrm{X} / \varnothing)$ : „Corect este să se evite uzul a prea multor substantive abstracte subordonate unul altuia la genitiv" [X] (p. $230 \$ 524)$

Corective-tip/eliptice $(\varnothing / \mathrm{Y})$ : „Este necesar, pe măsură ce din ce mai mulți oameni se educă, ca termenii culți care exprimă concepte specifice culturii grecești moderne $\left[\mathrm{Y}_{1}\right]$ să se răspîndească și să fie popularizați în masa de vorbitori. Și, pe de altă parte, indivizii din mediul urban ar trebui familiarizați, prin intermediul literaturii și al școlii, cu termenii populari [ $\mathrm{Y}_{1}$ ]” (p. $182 \S 415$ )

Corective-blazon/eliptice $(\mathrm{X} / \varnothing)$ : „o mulțime de scriitori insistă să folosească o ortografie neștiințifică, conservatoare și nejustificată (

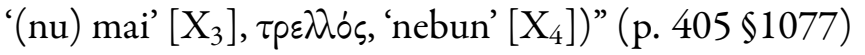

Corective-blazon/eliptice $(\varnothing / \mathrm{Y})$ : ,în ultimele decenii s-a creat necesitatea de a diferenția formele de feminin și masculin la substantivele nume de profesii [Y]. În limba oamenilor de rînd

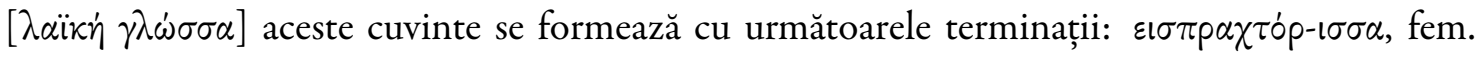

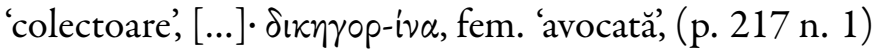

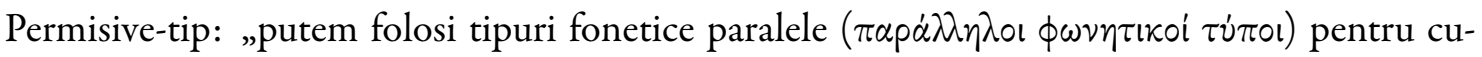
vinte, cînd unul este achiziționat cultural [Y], iar celălalt are origine populară [X]” (p. $101 \S 224)$;

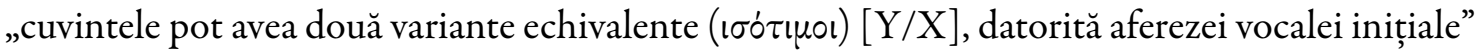
(p. 79\$172); „de obicei, împrumuturile mai vechi [Y] se declină; cele mai noi, nu [Y]” (p. 255 \$598)

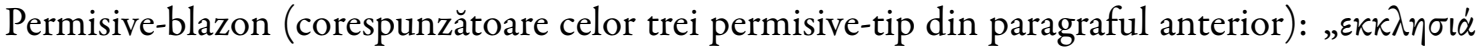

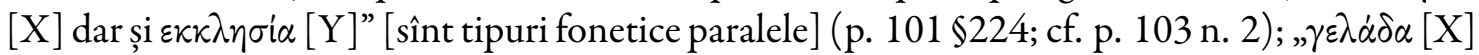

\footnotetext{
5̂́n toate exemplele care urmează am omis partea explicativă Z (chiar și atunci cînd gramatica o oferă), ceea ce le-ar transforma în exemple Z-eliptice; totuși, prin eliptic înțelegem aici X/Y-eliptic. Corective propriu-zise nu se găsesc cu ușurință în Gramatica lui Triantaphyllidis_fapt surprinzător. Corective eliptice X/Ø-blazon, i.e. corective care nu precizează varianta preferată se găsesc cu dificultate oriunde; se întîlnesc mai des exemple de corective-tip X/Ø („se vor evita genitivele subordonate”; „se vor evita construcțiile pasive”; „se va evita obscuritatea”; etc). Permisivele eliptice sînt simbolizate (X/Y), din moment ce $\mathrm{X} / \varnothing$ și $\varnothing / Y$ nu prezintă nicio diferență în cazul permisivelor.
} 


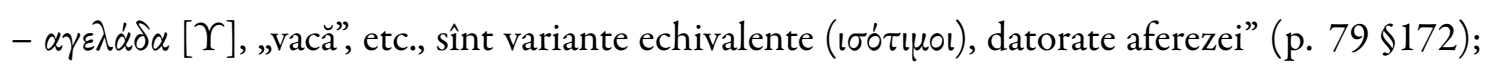

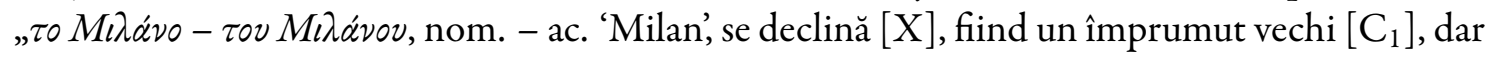
$\tau 0^{\prime} O \sigma \lambda 0-\tau 0 v^{\prime} O \sigma \lambda 0$, nom. - ac. 'Oslo' [Y], nu se declină, fiind un împrumut nou $\left[\mathrm{C}_{2}\right]$ '

Permisive-tip/eliptice $(\mathrm{X} / \mathrm{Y})$ : „În ceea ce privește substantivele nume de profesii care nu au formă de feminin, dacă se impune referirea fără ambiguități la o femeie, putem utiliza forma de masculin

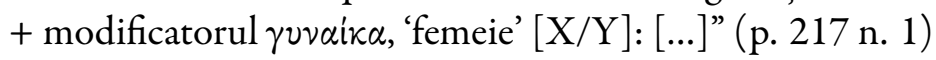

Permisive-blazon/eliptice (X/Y, corespunzătoare permisivelor-tip/eliptice din paragraful ante-

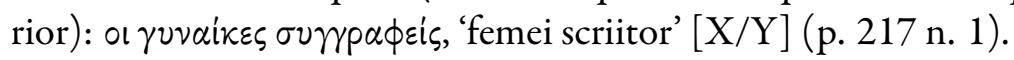

Cum se întîmplă cu toate actele de vorbire, fie ele lingvistice sau metalingvistice, corectivele pot fi și indirecte-dificil de identificat, deoarece se deghizează adesea în acte descriptive sau „constatative” (Austin, 1975, 3), i.e. în afirmații științifice nepărtinitoare. De pildă, un tabel cu declinări dintr-un manual de gramatică, precum cel din Fig. 2, va fi de obicei interpretat ca o expunere sistematică de adevăruri gramaticale (ca un complex 'expozitiv', în termenii lui Austin); dar el poate avea, indirect, și forța ilocuţionară a unei corective, i.e. forța unei 'exercitive' [engl. 'exercisitive'], în termenii lui Austin, ori a unei 'directive', conform terminologiei mai familiare a lui Searle. $\mathrm{Nu}$ putem ști care este forța aceea, decît dacă avem cunoștință de existența unor variante pe care tabelul le omite sau le întrebuințează greșit, ori dacă ne putem imagina un tabel alternativ (e.g., unul care să scoată în evidență variantele katharevousa mai degrabă decît cele demotice); nu putem ști deci pînă nu ne manifestăm critic față de tabelul respectiv, într-un fel sau altul. Nu doar permisivele pot fi transformate cu ușurință în adevărate corective; aproape orice afirmaţie gramaticală descriptivă poate fi interpretată ca prescriptivă, i.e. ca o corectivă, în anumite circumstanțe. În ceea ce ține de lingvistică, se poate trece foarte ușor de la „așa stau lucrurile” la „așa ar trebui să stea lucrurile".

Este motivul pentru care am luat în considerare numai permisivele explicite din Gramatica lui Triantaphyllidis. După cum am explicat mai devreme, adevăratele corective sînt greu de identificat, deoarece își păstrează o anumită ambiguitate în ceea ce privește forța lor. Unele dintre cele mai cunoscute corective din Gramatica lui Triantaphyllidis sînt de fapt cele pe care le omite; Gramatica a fost criticată tocmai pentru că lasă multe pe dinafară, e.g., adjectivele culte în $-\eta^{\prime} \zeta /-\dot{\varepsilon} \zeta(\varepsilon \pi \mu \mu \varepsilon \lambda \dot{\eta} \zeta / \dot{\varepsilon} \zeta$, ,,studios”) ori participiile din limba greacă veche în - $\omega \nu /-0 v \sigma \alpha /-0 \nu$ ( actuale”). Numai că nu se poate lua în considerare ceea ce nu există.

Urmînd gîndirii lui Setatos (1991, p. 34-36), permisivele sînt clasificate în funcție de tipul de diferențiere (i.e., condiția normativă) pe care îl exemplifică, de fapt. Rezultatele sînt expuse pe scurt în Tabela 1.

Tabela 1 este revelatoare în privința atitudinii lui Triantaphyllidis de atracție și toleranță față de variație. Observăm încă de la început că există acolo numai cîteva referiri la localisme și dialectalisme (48/1 689, i.e. 2.8\% din numărul total de permisive), care, după cum am văzut, jucaseră un rol important în conturarea standardului lui Psycharis. Există însă un număr relativ mare de referiri la variantele (diglosie) înalte/inferioare $(278,16.5 \%)$, ceea ce este sugestiv pentru „compromisul” lui Triantaphyllidis faţă de katharevousa, fapt pentru care a fost de fapt acuzat de către Psycharis. Este interesant totuși că Gramatica trimite la standarde ce depășesc și aspectul demotic, și katharevousa; sînt menționate tendințe noi, din variantele koine urbane și din normele locale (112, 6.6\%); afirmațiile gramaticale sînt sensibile la tendințe $(217,13 \%)$ și se afirmă adeseori (metalingvistic, ca să spunem aşa) că înseși regulile gramaticale pot fi aplicate numai aproximativ (50,3\%). Trebuie să remarcăm și faptul că Triantaphyllidis şi colaboratorii săi par să aplice constant un fel de sistem sociolingvistic primitiv de evaluare a uzului, probabil de origine lexicografică.

Mai departe, putem constata că viziunea lui Triantaphyllidis despre contactul lingvistic nu este una puristă, judecînd după numărul considerabil de trimiteri la originea cuvintelor, la străinisme, împrumuturi, forme adaptate, calcuri etc. $(151,8.9 \%)$. Cu greu se pot găsi în corpusul Gramaticii măcar 20 de 
Diferențiere în funcție de...

Permisive

\begin{tabular}{|c|c|c|}
\hline 1. & genuri/specii sau registre & 408 \\
\hline 2. & variante înalte/inferioare $(\delta เ \tau v \pi i \varepsilon \varsigma-\pi \partial \lambda \nu \tau v \pi i \varepsilon \varsigma)$ & 278 \\
\hline 3. & diferențe de sens / etimologie & 240 \\
\hline 4. & $\begin{array}{l}\text { frecvență („rar”, „mai rar”, „foarte rar”, ,adesea”, „uneori”, } \\
\text { „ocazional”, „vreo ..., „,(...), etc.) }\end{array}$ & 217 \\
\hline 5. & origine - cuvinte străine și străinisme & 151 \\
\hline 6. & $\begin{array}{l}\text { norme și răspîndirea lor („,koine”, „contemporan”, „nou”, } \\
\text { „modern” sau „limbă modernizată”) }\end{array}$ & 112 \\
\hline 7. & diferenţiere stilistică & 97 \\
\hline 8. & sentiment lingvistic - preferința și obişnuințele scriitorilor & 88 \\
\hline 9. & aplicarea strictă sau lejeră a regulilor & 50 \\
\hline \multirow[t]{2}{*}{10.} & variație dialectală/locală & 48 \\
\hline & Total & 1689 \\
\hline
\end{tabular}

Tabela 1: Tipuri de variație (permisive) în Triantaphyllidis et al. (1978).

corective propriu-zise referitoare la cuvintele străine, străinisme, iar și cele care există privesc mai degrabă ortografia, e.g. oferă instrucțiuni despre cum să fie mai bine transliterate cuvintele străine sau numele autorilor străini.

Triantaphyllidis lasă loc din plin variației stilistice-înțeleasă în termeni generali: ca acomodare la un gen sau registru (408, 24\%); ca scală de formalitate, aliniere la situație, indicator al intenției emițătorului sau al actului verbal specific executat de emițător (97, 5.7\%); ca marker într-un stil literar (88, 5\%); etc. Apar în Gramatică și 268 de citate din 44 de autori moderni greci, dar numai 25 din cîntece folclorice tradiționale-deși în Introducere (p. $k \beta^{\prime}$ ) se spune clar că „,norma gramaticală pe care o impune Gramatica se întemeiază pe bazele gramaticale ale cîntecelor folclorice tradiţionale și ale noii literaturi”, o afirmație ce se dovedește inexactă în ceea ce privește prima parte a ei.

Cu toate acestea, Gramatica Limbii Grecești Moderne (Demotică) este departe de a fi un ghid stilistic. Cea mai importantă contribuție a ei o constituie prezentarea sistematică a morfologiei grecești moderne. „Gramatica lui Trianta[ph]yllidis nu a fost depășită pînă azi ca cea mai autoritară prezentare a morfologiei grecești moderne” (Mackridge, 2009, 301). Și tocmai partea de morfologie a Gramaticii a fost cel mai des reluată, începînd cu Gramatica mică a lui Triantaphyllidis însuși (1965), concepută pentru uzul școlar.

Iordanidou (1999) este unul din primele studii care au arătat că GMS de azi admite o variație considerabilă (că, adică, nu reprezintă un standard „uniform”) ${ }^{6}$. Într-adevăr, standardul „mixt” al lui Triantaphyllidis s-a naturalizat (sau a fost justificat ca atare), s-ar putea spune, pe principiul lingvisticii descriptive, moderne, ce prevalează în lucrări de referință precum gramaticile și dicționarele descriptive. Ceea ce cîndva fusese denunțat ca normă „amestecată” artificială, devine acum, pe nesimțite, un ghid perceptual către „bogăţia” sau „pluralitatea” limbii grecești moderne. Formula lui Triantaphyllidis de standardizare (Koine $=$ demotic + forme culte, în funcție de necesitate) și-a asumat statutul de principiu descriptiv. Gramaticile moderne recente ale limbii grecești, inclusiv Holton, Mackridge \& Phillipaki-Warburton (1997), precum și toate marile dicționare marchează la ora actuală diferențele reale sau presupuse dintre formele

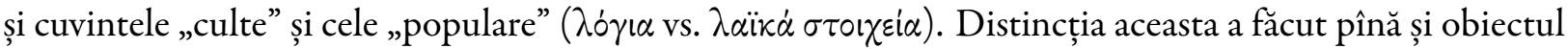
unei teoretizări gramaticale influențate de teoria marcării (Anastasiadi-Symeonidis \& Fliatouras, 2003).

\footnotetext{
${ }^{6}$ Haugen (1966b, p. 932-933) discută trei procedee de construire a unui standard: compararea — potrivită în cazul existenței unor dialecte înrudite-, arhaizarea - apelul la forme vechi reconstruite—, și statistica—care favorizează formele cu cea mai mare prezență în uz. Dar Haugen nu consideră niciunul dintre standardele astfel obținute ca fiind variaționale în sine; indiferent de caz, standardul, consideră el, este „unitar”. Pentru o discuție recentă asupra standardelor „unitare” vs. „compozite”, v. Pickl (2019). În ce mă privește, cred că orice standard admite variație, nu doar cele „compozite”, cum este și GMS.
} 
Aproape că trebuie să ni se reamintească faptul că și permisivele sînt acte ale prescriptivităţii.

Gramaticienii limbii grecești moderne au ajuns să ia ca lucru de la sine-înțeles existența —și proeminențavarietăţii urbane vorbite și scrise, probabil, a clasei de mijloc educate (cf. Mackridge, 1985, p. vi). Holton, Mackridge \& Phillipaki-Warburton (1997, p. XV) afirmă în Introducerea la Gramatica lor școlară că

the language described in our grammar is the form spoken and written by educated Greeks from the urban centers of Greece, which, while it is primarily based on demotic vocabulary, phonology, morphology and syntax, displays a significant influence from katharevousa.

[rom.: limba descrisă în gramaticile noastre este forma vorbită și scrisă de grecii educați din centrele urbane ale Greciei, care, deși se bazează pe vocabularul, fonologia, morfologia și sintaxa demotice, etalează o influență semnificativă din partea katharevousa]

Ar fi putut fi aceasta o declarație a lui Triantaphyllidis însuși, în ciuda faptului că Gramatica lui Holton, Mackridge \& Phillipaki-Warburton este marcant diferită de cea a lui Triantaphyllidis, precum și a concesiei lor că „limba greacă s-a schimbat considerabil de atunci [din 1941, cînd se publicase Gramatica lui Triantaphyllidis]" (ibid.).

Cum de a reușit standardul lui Traintaphyllidis să învingă—asta dacă, pînă la urmă, chiar este standardul lui cel care a învins? Pentru a răspunde la această întrebare, trebuie să analizăm felul în care se instituţionalizează, se mediatizează și se difuzează normele. Normele nu se reproduc exclusiv prin educație formală. În partea următoare a lucrării ne vom opri asupra felului în care instrucțiunile corective sînt organizate în repertorii și sînt mediatizate prin ghiduri și îndreptare de utilizare, articole de cultivare a limbii, prin presă, televiziune, emisiuni radio și site-uri specializate.

\section{Repertorii}

După ce a adoptat katharevousa (varietatea înaltă), regimul dictatorial din 1967-1974 a făcut tot ce i-a stat în putință să-i discrediteze folosirea. Tocmai din pricina asocierii ei cu regimul juntei, și-a pierdut legitimitatea. Folosirea greșită și abuzivă a variantei katharevousa în timpul dictaturii a ajuns curînd să fie incriminată și să-şi piardă prestigiul (Frangoudaki, 1992, p. 368-370).

În 1976, după instaurarea democrației parlamentare, reforma educației lingvistice a închis „Chestiunea limbii grecești” prin legiferarea unui standard care a ajuns să fie cunoscut, mai ales de către lingviști, ca

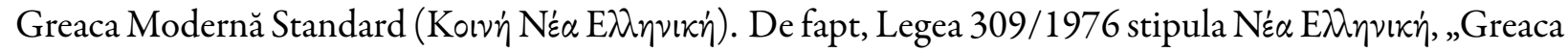
Modernă”, ca „instrument și obiect de studiu la toate nivelurile de învăţămînt general”. Greaca modernă era definită ca „[variantă] demotică ce devine instrument de exprimare panhelenic, utilizat de poporul grec

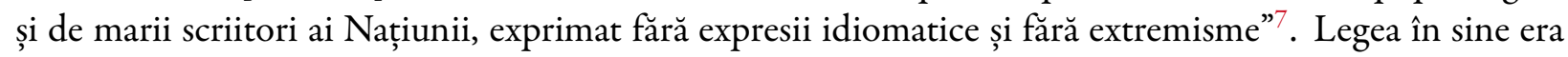
scrisă în katharevousa (Mackridge, 2009, p. 319).

În 1982, printr-o reformă ortografică ulterioară, sistemul politonic (cu diacritice multiple) al textelor grecești vechi, folosit pînă atunci și la scrierea textelor grecești medievale şi moderne, a fost înlocuit de sistemul monotonic. Principalul actant al implementării acestei reforme ortografice a fost Emmanuel Kriaras (1983, p. 213-263). Sistemul politonic fusese creat pentru a marca accentul tonal al limbii grecești vechi, care, pînă spre epoca koine elenă, se transformase într-un accent dinamic; sistemul monotonic nu este doar mai simplu, ci și reprezintă mai bine tiparele accentuale ale limbii grecești moderne. Așa se face că reforma lui Kriaras nu a întîmpinat rezistență, deși în anumite cercuri politice și literare atașamentul

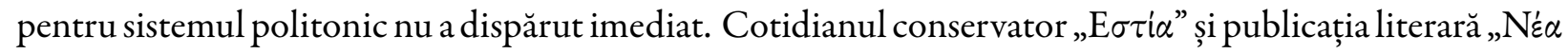
E $\sigma \tau i \alpha$ ”, printre altele, se tipăresc și la ora actuală cu diacritice politonice; dar la fel s-a întîmplat și cu revista

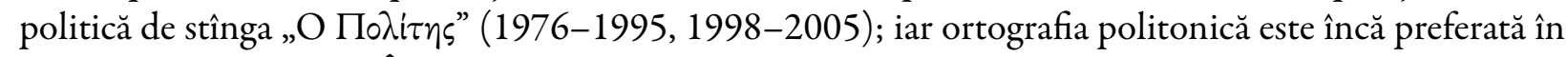
registrul înalt al poeziei. În discursul public, asocierea dintre demotic și monotonic, pe de o parte, și dintre

\footnotetext{
${ }^{7} \mathrm{O}$ formulare uimitor de asemănătoare, într-o construcție sociolingvistică radical diferită, se găsește la Longmore (2007): „fără idiom sau ton” (Hugh Jones).
} 
katharevousa și politonic rămîne în continuare puternică, în ciuda faptului că, istoric, este eronată; atît Psycharis, cît și Triantaphyllidis foloseau ortografia politonică.

Dezbaterile lingvistico-ideologice au continuat mult după rezolvarea oficială a „Chestiunii limbii” (Moschonas, 2001a, 2004, 2009, 2014). Unele au reafirmat și au reactualizat vechea prăpastie dintre variantele katharevousa și demotică. De pildă, vechea dispută dacă limba greacă veche ar trebui sau nu predată în învăţămîntul secundar (Kriaras, 2010; Koutsou, 2004; Panagiotakakis, 2014) era permanent reluată în presă și în diatribe de lungimi considerabile, sub impresia aberantă că 'Greaca veche $\approx k a t h a-$ revousa', i.e. că varietatea arhaică, puristă reprezintă cel mai apropiat echivalent pentru 'Greaca veche',

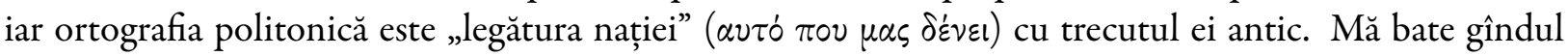
că, redat în termenii psihologiei, identificarea limbii grecești vechi cu katharevousa se califică drept caz de transfer-întocmai cum identificarea limbii cu forma ei scrisă este un caz de metonimie. În presă se vorbește despre greaca veche ca și cum ar fi constat dintr-o singură și uniformă varietate (cea atică, mai des).

Pe lîngă cele reciclate, răsar alte și alte probleme în urma reformelor lingvistice, mai ales în vremea de după mijlocul anilor '80: noua realitate UE a scos în arenă probleme legate de plurilingvism și contacte lingvistice. Pe tot parcursul anilor '90, relativa îngrijorare în legătură cu influența limbii engleze asupra limbii grecești a revitalizat o atitudine puristă în genul katharevousa față de împrumuturile din engleză, mai ales în domeniul terminologiilor tehnice. Moschonas $(2004,2009)$ arată că realități precum: conturarea noilor probleme, după schimbarea regimului lingvistic, din 1976; felul în care aceste probleme, vechi şi noi, sînt abordate şi se manifestă în presă; argumentele aduse în sprijinul lor-toate indică faptul că „misiții ideologiilor lingvistice” [engl.: „language-ideology brokers”] (Blommaert, 1999, p. 9), indiferent de tabăra din care fac parte, împărtășesc aceeași concepție despre GMS ca limbă desăvîrşită, o limbă a deplinătăţii lingvistice [engl.: „of full languageness”] (Blommaert, 1999, p. 431), omogenă, de o minunată uniformitate, dar aflată într-o perpetuă nevoie de apărare în fața „duşmanilor interni și externi”-o limbă care a ajuns (în sfîrșit!) să se suprapună perfect peste „teritoriul” real sau simbolic al naţiunii (Moschonas, 2004). Evident, „Chestiunea limbii” se încheiase. Ni se născuse un Standard.

Am putea presupune, luîndu-ne după Thomas (1991, p. 100-114), că normele lingvistice (dintre care unele se leagă de purism, excelent studiat de Thomas) urmează căile ideologiilor, i.e. că se propagă în valuri, răspîndindu-se gradual, în cercuri concentrice: de la o elită, la un mic cerc de simpatizanți și promotori, și, prin aceștia, la „publicul larg” (dacă există o asemenea entitate colectivă). Pentru ca acest model de diseminare de sus în jos să fie eficient, trebuie să fie întrunite mai multe condiții: standardul trebuie să fie instituţionalizat; într-adevăr, instituțiile de învățămînt joacă un rol uriaș în diseminarea și consolidarea normelor lingvistice. Trebuie, de asemenea, să fie mediatizat; toate mijloacele de comunicare în masă existente (presa scrisă, radioul, televiziunea, internetul), despre care se crede că au forța de „a educa publicul”, sînt puse în slujba standardizării, dacă nu altfel, prin puterea exemplului: prin respectarea autoimpusă a normei. Nu în ultimul rînd, diseminarea standardului trebuie să se facă pe scară largă. În prezența acestor trei precondiții, se formează treptat un habitus lingvistic, care, în opinia lingviștilor-i.e. a principalilor promotori ai normelor lingvistice一 exprimă singurul „sentiment lingvistic comun” sau „intuiția lingvistică” a unui vorbitor nativ, o intuiție pe care o vor invoca din nou atunci cînd va trebui să descrie normele prescrise de ei înșiși ori de predecesorii lor (Bourdieu, 1991).

Să vedem atunci cum se propagă normele unei limbi standard prin texte metalingvistice care se însărcinează cu lucrul asupra normelor unui standard. Din nou, ne vom concentra asupra unităților minimale prescriptiviste: corectivele. Diferite grupuri de corective formează diferite repertorii, care pot fi comparate fie sincronic, fie diacronic; cînd sînt comparate sincronic, scot la lumină standarde concurente într-o comunitate la un moment istoric dat; cînd sînt comparate diacronic, scot la lumină modificări ale standardului de-a lungul timpului. Repertoriile sînt cuprinse în ceea ce eu numesc simplu Îndreptare, i.e. texte metalingvistice care prezintă și comentează repertoriile de corective, asupra cărora ne oprim acum. 


\section{Studiul 2: Indreptare}

Odată cu schimbarea regimului lingvistic, din 1976, s-au înfiripat ideologii lingvistice în număr mare. După cum se arată în Moschonas (2005c), după 1976 s-a înregistrat o creștere bruscă a numărului de lucrări dedicate uzului lingvistic. Numai cîteva dintre aceste prime îndreptare se mai află astăzi în uz (e.g., Diplas, 1977; mesevrinos, 1978; Dorbarakis, 1979). Cele de mai tîrziu se retipăresc constant, deși rareori sînt aduse la zi. Unele dintre ele conțin texte publicate inițial în presă (e.g., Papazafeiri, 1987, 1997; Haris, 2003, 2008; Pappas, 2004); altele se adresează în mod specific jurnaliștilor (e.g., Karzis, 1995; AПE 1988; Maronitis, n.d.; Tzannetakos, [1991]). În multe dintre marile ziare grecești, apar cu regularitate ,articole de cultivare a limbii" ( $\delta$ เop $\theta \omega \tau \iota k \varepsilon \dot{\varepsilon} \sigma \tau \dot{\eta} \lambda \varepsilon \varepsilon$; cf. Moschonas, 2001b) —un tip aparte de articole ce oferă sfaturi și indicații legate de problemele uzului lingvistic (mă voi ocupa puțin mai jos de trei exemple de acest gen).

Nu numai presa tipărită oferă instrucțiuni și sfaturi corective. Acestea sînt transmise și prin radio și televiziune. Kriaras (1988) conține celebrele sale foiletoane televizate, cum ar putea fi numite, transmise la nivel naţional pe canalul de televiziune ERT1, în perioada 1985-1987. Textele din Lypourlis (1994) au fost mai întîi transmise pe canalul privat de radio Paratiritis (din Salonic). Popularul show de televiziune „O Iar în zilele noastre există mai multe site-uri care oferă instrucțiuni pe probleme de gramatică și uz; e.g.,

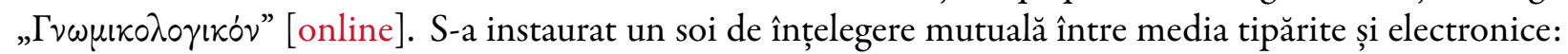
cele mai multe articole din Haris $(2003,2008)$, publicate inițial în presă, au fost ulterior puse la dispoziția publicului pe weblog-ul autorului [online]; invers, Sarantakos (2007) reia texte care au apărut mai întîi pe weblog-ul autorului [online]; pentru alte chestiuni legate de weblog-uri dedicate limbii, v. Vassilaki (2012). oi folosi pentru acest gen de texte metalingvistice termenul îndreptare ['Usage Guides'] (TiekenBoon van Ostade, 2010), indiferent de mediul în care apar și se manifestă, și formula articole de cultivare

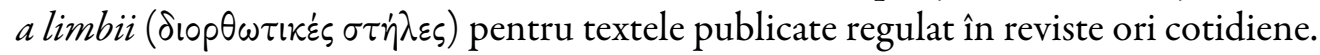

Moschonas (2001b) compară și analizează fragmente din trei articole de cultivare a limbii:

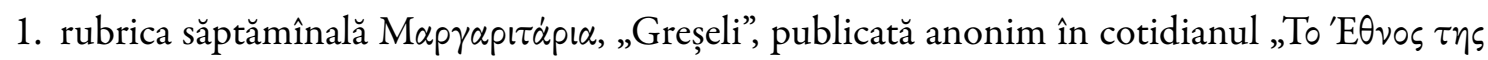

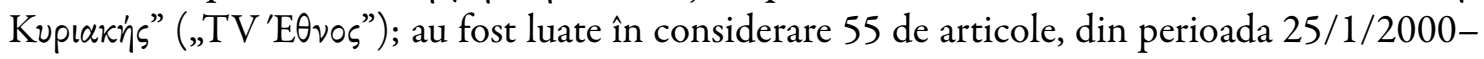
25/11/2001;

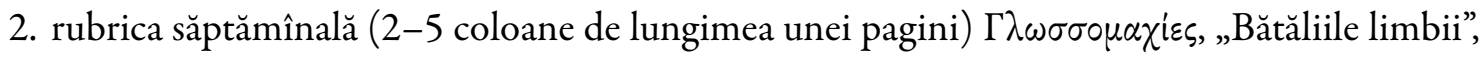
publicată în magazinul TV „P $\alpha \delta ı \tau \eta \lambda \varepsilon \delta ́ \rho \alpha \sigma \eta ”, ~ s u b ~ p s e u d o n i m u l ~ \Gamma \lambda \omega \sigma \sigma \alpha \mu \nu ่ v \tau \omega \rho, ~ „$ Apărătorul limbii” [Nikos Politis]; au fost examinate 87 de texte: primele 21 și ultimele 66 din întreaga perioadă de viață a rubricii, 16/4/1994-22/6/2001;

3. rubrica bisăptămînală (3 coloane de lungimea unei pagini) Mıxṕd $\gamma \lambda \omega \sigma \sigma \iota k \dot{\alpha}$, „Minore chestiuni lingvistice” (mai departe: „Minore ch. l.”), publicată în ediția de sîmbătă a cotidianului

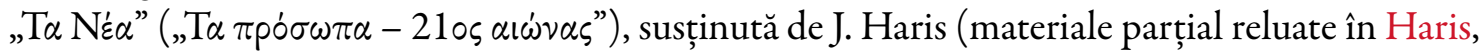
2003): am avut în vedere 43 de texte, din perioada 13/8/1999-4/8/2001.

Rubrica săptămînală M $\alpha p \gamma \alpha \rho ı \dot{\alpha} p ı \alpha$, „Greșeli”, cu texte umoristice care vizează bîlbele, gafele și malapropismele produse în emisiuni de televiziune, merită o atenție deosebită deoarece pune la dispoziția cercetătorului o colecție excelentă de corective. Structura unei corective (prohibitiv-normativ-explicativ) este clar

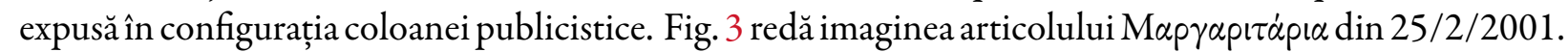
Coloana prezintă, de obicei, 3-5 corective-în cazul de faţă, numărul minim: 3. Se observă că fiecare secvență corectivă (indicată printr-un asterisc ł ) este împărțită în exact trei părți. Fiecare este precedată

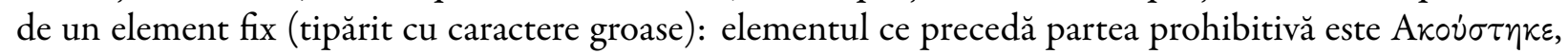
„S-a auzit/spus”; cel ce precedă partea normativă, To $\sigma \omega \sigma \tau \dot{\prime}$, „Corect este”, iar cel al părții explicative, To $\lambda \dot{\alpha} \theta \circ \varsigma$, „Greșeala constă în”. Mai întîi este precizată prohibitiva; la urmă, normativa; la mijloc avem explicativa (în corectiva a treia din Fig.3, după partea normativă se oferă în plus cîteva informaţii de natură enciclopedică, ce ar fi trebuit, în mod normal, să apară în cuprinsul explicativei; modelul acesta 


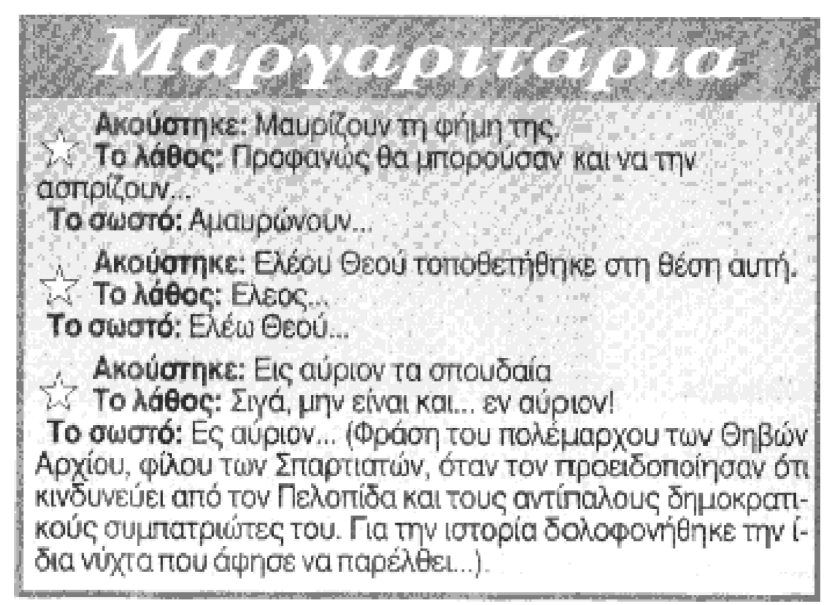

Figura 3: „Greșeli”, 25/2/2001.

este mai degrabă neobişnuit). Explicativa ia de obicei forma unei remarce umoristice. Iată o traducere (aproximativă, din păcate) a celor trei corective din Fig. 3:

S-a spus: Îi înnegresc [ $\mu \alpha u p i \zeta o v v$, demotic] faima

* Greșeala constă în: Păi, nu te poți aștepta să i-o înălbească...

Corect este: Auavpóvouv [arhaic]

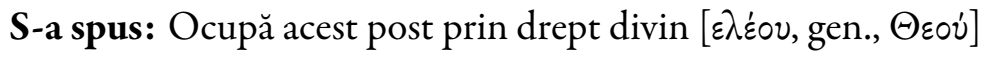

* Greșeala constă în: Doamne ferește...

Corect este: $\mathrm{E} \lambda \dot{\varepsilon} \omega$, dat.

S-a spus: Treburi serioase la mîine [Eıs $\alpha$ v́pıov $\tau \alpha \sigma \pi \circ v \delta \alpha i \alpha]$

Æ Greșeala constă în: Bine că n-ai spus: $\varepsilon v$ aúpıov [în mîine]

Corect este: $E_{\varsigma}$ av́piov

([pentru că este] o construcție fixă, rostită de Archias, prieten al spartanilor, cînd a fost avertizat de complotul ce se pusese la cale împotriva sa; e adevărat, Archias a murit în acea seară [Plutarh, Viața lui Pelopidas 10.4; de menționat totuși că ediția Perrin - 1917. Plutarch, Plutarch's Lives, Cambridge, MA. Harvard University Press. London, 5 - stabilește textul

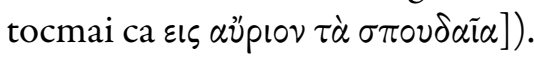

Cele mai multe dintre corective nu se referă la greșeli de limbă (sau la ceea ce se consideră a fi greșeli de limbă). Ci la bîlbe, gafe, scăpări („erori” în sensul lui Goffman, 1981, p. 208-213). Este cazul corectivelor prezentate în Fig. 4; iată o traducere a ultimei secvențe corective:

S-a spus: Am terminat pe locul doi printre primii

* Greșeala constă în: Păi, ar fi trebuit să te faci expert în statistică

Corect este: Ajunge 'pe locul doi'; restul este de prisos

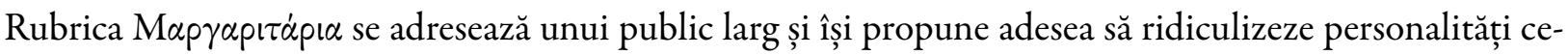
lebre ale mass-mediei. Este directă și ușor de înțeles; putem spune că împărtășește cu publicul ei cele mai comune presupoziții. Deja din Fig. 3 putem extrage următoarele două presupoziții: mai întîi, că expresiile fixe din literatura veche nu trebuie alterate, nu trebuie vulgarizate în niciun fel; și, în al doilea rînd, că cei care comit greșeli sînt ignoranți, lipsiți de educație și își merită batjocura. Ținta ultimă a rubricii

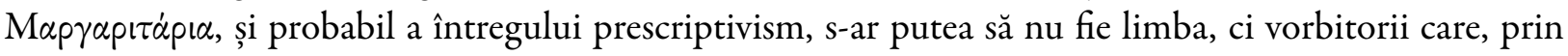




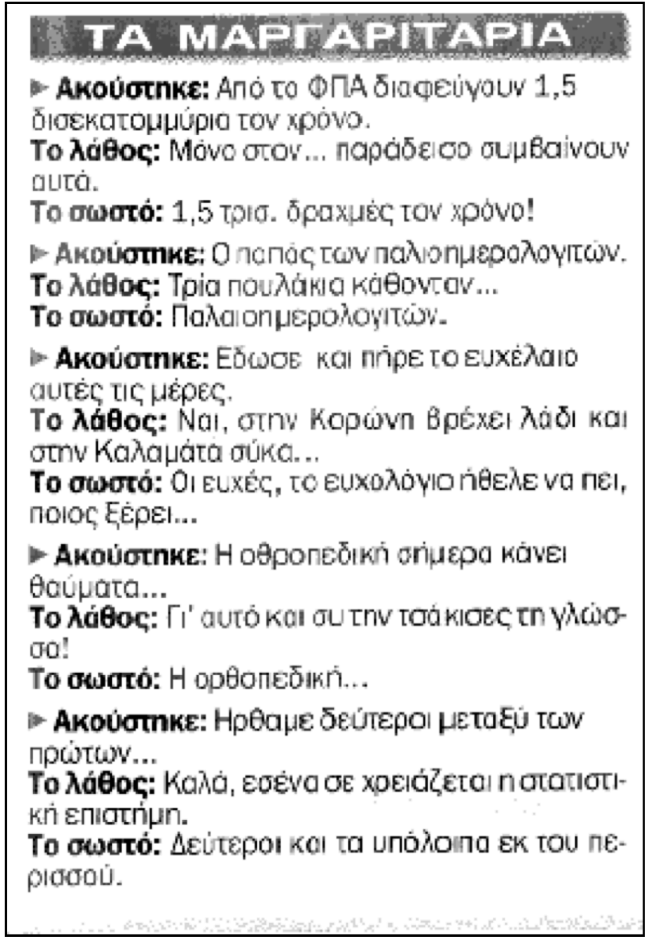

Figura 4: „Greșeli”, 27/5/2001.

felul în care folosesc limba, sînt arătați cu degetul pentru „prostie și lipsă de gust” (Swift, 1984, p. 253). Prescriptivismul social și lingvistic merg adesea mînă-n mînă (Mugglestone, 2003, p. 1).

Identificarea corectivelor în celelalte două rubrici, $\Gamma \lambda \omega \sigma \sigma o \mu \alpha \chi i \varepsilon \varsigma$, ,Bătăliile limbii”, și Mıкpd $\gamma \lambda \omega \sigma \sigma ı \alpha \dot{\alpha}$, „Minore chestiuni lingvistice”, nu este la fel de lesnicioasă. Acestea două sînt mult mai argumentativemult mai 'metalingvistice', s-ar putea spune. Sînt ghidate de dogmă, iar instrucțiunile corective pe care le emit sînt mai rafinate. $\Gamma \lambda \omega \sigma \sigma o \mu \alpha \chi i \varepsilon \varsigma$ și Mıкpá $\gamma \lambda \omega \sigma \sigma \kappa \kappa \dot{\alpha}$ se adresează unor tipuri diferite de public, de-a lungul unor etape diferite din evoluția speciei îndreptarelor de limbă; dar fac și (mai cu seamă) altceva: reprezintă mentalități diferite. „Bătăliile limbii” este o rubrică oarecum de modă veche; etalează o abordare a chestiunilor lingvistice într-o manieră enciclopedică, decontextualizată, prezentîndu-le cu tot formalismul intimidant al gramaticilor tradiționale. Și chiar dacă apare tipărită într-un ghid TV, rubrica se axează mai ales pe discursul scris. Și „Minore ch. l.” se ocupă de discursul scris, dar cazurile pe care le discută sînt selectate cel mai frecvent din literatura contemporană (greacă sau tradusă în greacă). Autorul rubricii pretinde (în mod fals) că se bazează pe lingvistica contemporană și își afirmă adesea atitudinea „demitologizantă” asupra problemelor limbii. Este vulgarizant [engl. demoticist] în mod deschis și nu tolerează „arhaisme nenecesare”. Și, din cînd în cînd, își bate joc de abuzurile katharevousa. În ciuda modestului nume pe care îl poartă, „Minore ch. l.” devine o rubrică polemică atunci cînd este dominată de motive ideologice.

Cîteva dintre diferențele ideologice și mentalitare ale rubricilor pot fi deduse din analiza Tabelei 2. Apar acolo caracteristici semantice binare ce sintetizează rezultatele analizei de conținut asupra celor trei serii de articole (Moschonas, 2001b). Semnul întrebării indică faptul că o anumită serie de articole nu prezintă în mod cert respectiva caracteristica semantică; 'n/a' înseamnă că distincția semantică nu este relevantă pentru publicația avută în vedere.

În ceea ce privește ideologia lingvistică a autorilor lor (exprimată en passant ori ca profesiune de credință), și „Bătăliile limbii”, și „Minore ch. l.” se declară demoticiste și acceptă ideea unei limbi comune uniforme: un Standard. Totuşi, numai prima acceptă ideologia unei „continuități neîntrerupte” ( $\alpha \delta i \alpha \sigma \pi \alpha \sigma \tau \eta$

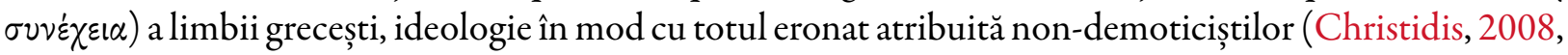
p. 105). „Minore ch. l.” este mult mai puțin tolerantă față de arhaisme. Cu toate că, pe față, și „Bătăliile 


\begin{tabular}{|c|c|c|c|}
\hline & „Greșeli” & $\begin{array}{l}\text { „Bătăliile } \\
\text { limbii" }\end{array}$ & $\begin{array}{c}\text { „Minore ch. } \\
\text { 1." }\end{array}$ \\
\hline demotic & $\mathrm{n} / \mathrm{a}$ & $\begin{array}{c}+ \\
(?)\end{array}$ & + \\
\hline $\begin{array}{l}\text { comun } \\
\text { /Standard }\end{array}$ & $\mathrm{n} / \mathrm{a}$ & $\begin{array}{c}+ \\
(?)\end{array}$ & $\begin{array}{c}+ \\
(?)\end{array}$ \\
\hline $\begin{array}{l}\text { continuitate } \\
\text { istorică }\end{array}$ & $\mathrm{n} / \mathrm{a}$ & + & - \\
\hline $\begin{array}{l}\text { arhaisme } \\
\text { tolerate }\end{array}$ & $\begin{array}{l}+ \\
(?)\end{array}$ & + & - \\
\hline $\begin{array}{l}\text { se declară } \\
\text { puristic }\end{array}$ & $\mathrm{n} / \mathrm{a}$ & $\overline{(?)}$ & $\overline{(?)}$ \\
\hline este puristic & + & + & + \\
\hline $\begin{array}{l}\text { se concentrează } \\
\text { asupra limbii scrise }\end{array}$ & - & + & $\begin{array}{c}+ \\
(?)\end{array}$ \\
\hline pro-monotonic & $\mathrm{n} / \mathrm{a}$ & + & + \\
\hline $\begin{array}{l}\text { variație } \\
\text { tolerată }\end{array}$ & $\mathrm{n} / \mathrm{a}$ & $\begin{array}{c}+ \\
(?)\end{array}$ & $(?)$ \\
\hline $\begin{array}{l}\text { corect-greșit } \\
\text { (corectitudine) }\end{array}$ & + & + & + \\
\hline $\begin{array}{l}\text { bun-rău } \\
\text { (elocvență) }\end{array}$ & - & - & + \\
\hline $\begin{array}{l}\text { Lexical- } \\
\text { Frazeologic }\end{array}$ & + & + & + \\
\hline $\begin{array}{l}\text { Gramatical- } \\
\text { Morfologic }\end{array}$ & - & + & - \\
\hline $\begin{array}{l}\text { Istoric- } \\
\text { Etimologic }\end{array}$ & - & + & - \\
\hline
\end{tabular}

Tabela 2: Comparație între cele trei rubrici. Sursa: Moschonas (2001b, p. 60).

limbii”, și „Minore ch. l.” se prezintă ca non-puriste, în practică amîndouă demonstrează o atitudine puristă față de împrumuturi-atitudine care, în cazul „Bătăliilor limbii”, merge pînă acolo încît pretinde adaptarea cuvintelor străine prin calchiere, și, în cazul „Minorelor ch. l.”, pînă la a sugera selecția între mai multe posibile forme calchiate. Ambele rubrici au în vedere limba scrisă: prima își selectează materialul cu precădere din cotidiene, în timp ce a doua preferă literatura contemporană. În ceea ce privește ortografia, ambele susțin aspectul monotonic. Spre deosebire de ele, „Greșeli”, după cum am arătat și mai sus, are în vedere aproape exclusiv limba vorbită spontan. În ciuda unor declarații ocazionale, nicio serie de articole prezentată în Tabela 2 nu manifestă toleranță față de variație. Toate sînt puternic polarizate, urmînd distincția greșit-corect; corectitudinea este considerată a fi absolută și fără grade de comparație. Ocazional, „Minore ch. l.” evaluează fragmente de discurs și pe baza unui vag criteriu estetic (de-a lungul dihotomiei 'bun-rău', cu multele lor sinonime). Criteriul corectitudinii primează totuşi, în defavoarea celui estetic, în toate cele trei rubrici.

Un fenomen interesant observabil tot în Tabela 2 este transformarea graduală a normelor limbii standard, după cum reiese din analiza modelelor instrucțiunilor corective care predomină în fiecare serie de articole. Modelul asociat inițial cu Gramatica Limbii Grecești Moderne (Demotică) a lui Triantaphyllidis

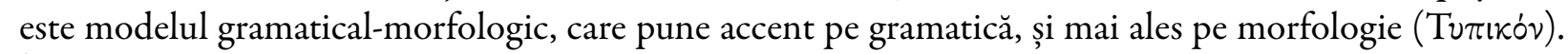
Îndreptarul lui Papanoutsos \& Stavrou (1965) este exemplar pentru abordarea morfologică: a fost gîndit ca auxiliar al Triantaphyllidis et al. (1978) și, lăsînd la o parte cele cîteva remarce ortografice inițiale și un Appendix despre sistemul monotonic, oferă instrucțiuni asupra declinării substantivelor, adjectivelor, pronumelor și asupra conjugării verbelor. Reproducem aici primele trei precizări (enumerarea este consecutivă) în legătură cu declinarea substantivelor (Papanoutsos \& Stavrou, 1965, p. 31-32): 
10. Nominativul singular al substantivelor masculine. Se termină întotdeauna în - $\varsigma$; înainte de $-\varsigma$ apare una din cele cinci vocale ale limbii noastre, $a, i, u, e, o: \alpha \gamma \omega \dot{\omega} \nu \alpha-\varsigma$,agonie”, $\varepsilon \rho \gamma \alpha \dot{\tau} \eta \eta-\varsigma$

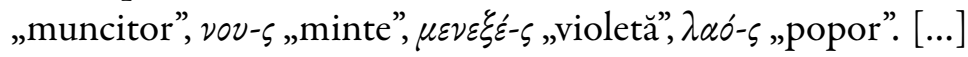

11. Acuzativul singular al substantivelor masculine se formează prin eliminarea lui $-\varsigma$ de la forma de nominativ: $\alpha \gamma \omega \dot{\omega} \nu \alpha, \varepsilon \rho \gamma \alpha \dot{\tau} \eta, \nu 0 v, \mu \varepsilon v \varepsilon \xi \dot{\xi}, \lambda \alpha o^{\circ}$ [...]

12. Vocativul singular al substantivelor masculine terminate în $-o$ se formează $\mathrm{cu}-\varepsilon[-e]$ ( $\gamma \iota \alpha \tau \rho-\dot{\varepsilon}$, "doctor"); la celelalte cuvinte, este identic cu acuzativul [...].

Pe de altă parte, modelul istoric-etimologic, asociat iniţial cu katharevousa (varietatea înaltă), pune accentul pe „continuitatea” limbii grecești și tinde să explice morfologia contemporană ca digresiune față de

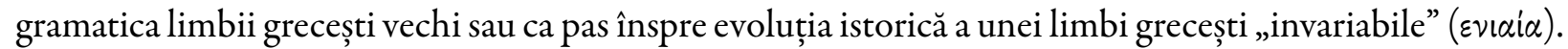
În ciuda asocierii lui cu varianta înaltă, modelul istoric-etimologic predomină în toate discuțiile despre ortografie, cu excepția celor care vizează sistemul monotonic.

În sfirșit, modelul lexical-frazeologic pune accentul pe vocabular, are în vedere mai ales cuvintul și expresiile fixe. Este un model popular, prin aceea că se preocupă de elemente lexicale referențiale, despre care „se poate crede cu ușurință că sînt recunoscute de vorbitorii nativi” (Silverstein, 2001, p. 400).

Toate cele trei modele de instrucțiuni corective se găsesc, de obicei, în îndreptarele existente la ora actuală, dar nu în aceeași măsură. Revelatoare în acest sens poate fi comparația între mai vechea rubrică „Bătăliile limbii”, pe de o parte, și mai noile „Minore ch. l.” și „Greșeli”, pe de altă parte. După cum am văzut, „Bătăliile limbii” adoptă o perspectivă enciclopedică asupra chestiunilor limbii prin utilizarea tuturor celor trei modele de instrucțiuni corective; în mod obişnuit, se selectează un număr de cuvinte sau de expresii care sînt „corectate” apoi pe temeiul morfologiei sincronice și diacronice documentate în gramaticile tradiționale și în alte lucrări de referință. „Greșeli” și „Minore ch. l.” par să considere de la sine înțeles modelul gramatical-morfologic; în schimb, își întemeiază instrucțiunile pe modelul lexicalfrazeologic. Mai multe detalii despre această transformare a normelor se află la Moschonas (2001b, p. 6164 și 2005c).

Două chestiuni trebuie subliniate în legătură cu această transformare. Mai întîi, modelul gramaticalmorfologic nu a fost abandonat; este asumat tacit. Este considerat acum de la sine înțeles, deoarece varietatea demotică pe care o susține s-a autoproclamat „limbă comună”, „limba poporului”, o limbă „nativă”i.e. s-a autoproclamat Standard. Evident, nu așa au stat lucrurile întotdeauna. Dacă privim din nou mai sus, la fragmentul excerptat din Papanoutsos \& Stavrou (1965), , observăm că autorii scriu de parcă s-ar adresa celui care învață limba greacă modernă ca limbă străină. Astfel, modelul gramatical-morfologic este invocat numai atunci cînd o anumită variantă are nevoie să fie justificată ca normă; altminteri, este considerat a fi de la sine înțeles. Apoi, modelul lexical-frazeologic este ideal pentru acomodarea unui standard compozit, ca cel al lui Triantaphyllidis, pentru că tratează cuvintele și expresiile ca unităţi de

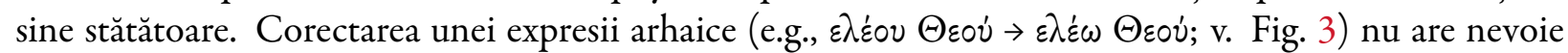
să ia în calcul vreo alternativă; de fapt, singura alternativă la o expresie arhaică greșită este cea corectă! $!^{8}$ Fiecare cuvînt sau expresie arhaic/ă este tratat/ă ca un caz separat, și fiecare este considerat/ă ca fiind „,invariabil/ă” și ,uniform/ă” în izolarea sa—întocmai ca limba standard căreia îi aparține. Modelul lexicalfrazeologic permite corectarea arhaismelor și a construcțiilor de tip katharevousa la egalitate cu cuvintele și construcțiile demotice, „neutralizînd” astfel distincția anterioară dintre variantele înaltă și inferioară. Așa se face că modelul lexical-frazeologic reprezintă o soluție eficientă la „problema” standardului compozit, neuniform.

Corectivele nu apar izolat. Ele tind să formeze repertorii corective (Moschonas, 2008, p. 45), i.e. seturi de corective, grupate în îndreptare sau în texte metalingvistice similare. Se poate presupune că repertoriile

\footnotetext{
${ }^{8}$ Există mai multe îndreptare dedicate expresiilor arhaice culte; ele se autodefinesc ca Dicționare și, într-adevăr, constau în intrări ordonate alfabetic; e.g. Markantonatos (1998). Iordanidou (2001b) este alcătuit pe baza unui corpus de texte selectate din presa grecească.
} 
corective împărtășesc aceleași presupoziții și că domină într-un mediu oarecare, pentru o perioadă de timp. Repertoriile corective sînt repertorii colective.

Dați-mi voie să aduc în discuție un asemenea repertoriu și să-i dezvălui presupozițiile. Papakostas (2006) este un articol de ziar intitulat Ce fel de limbă se creează prin media. A fost scris de către un filolog care, la vremea aceea, era și membru al Consiliului Național Grec de Radio și Televiziune (E $\Sigma$ P:

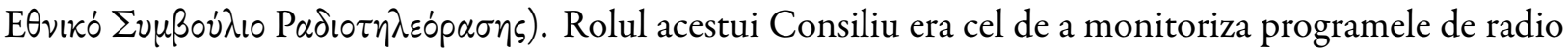
și televiziune pentru a se asigura că respectă normele și legile în vigoare. Legea 3592/2007 art. $20 \$ 2$ recomandă „uzul corect al limbii grecești” în presa tipărită sau electronică. Prin urmare, repertoriul pe care urmează să-l examinăm poate fi considerat ca un caz de prescriptivism instituţional.

Papakostas (2006) crede că publicului ar trebui să i se atragă atenția asupra următoarelor „fenomene de patologie lingvistică” (explicațiile dintre paranteze îmi aparțin):

* $\tau \omega \nu \nu \pi \alpha \rho x o ́ v \tau \omega \nu \pi \rho \beta \beta \lambda \varepsilon \dot{\varepsilon} \psi \varepsilon \omega \nu$

[violarea regulii de acord nominal din morfologia arhaică: „dintre existenții (masc.) predicții (fem.)” în loc de „dintre existentele (fem.) predicții (fem.)”]

* $\tau \omega \nu \alpha \nu \alpha \lambda \eta \phi \theta \dot{\varepsilon} \nu \tau \omega \nu \pi \rho \omega \tau 0 \beta \circ \nu \lambda \iota \dot{\omega} \nu$

[idem: „dintre luații (masc.) inițiative (fem.)"]

* $\pi \imath \theta \alpha \alpha \dot{~ i ̂ n ~ l o c ~ d e ~} \pi \imath \theta \alpha \nu o ́ v$

[morfologia adverbului: terminația „demotică” nepotrivită pentru „probabil”]

* $\varepsilon \kappa \tau \omega \nu$ ovK $\dot{\alpha} \nu \varepsilon v$ în loc de $\varepsilon \kappa \tau \omega \nu \omega \nu$ ovK $\dot{\alpha} v \varepsilon v$

[expresia din greaca veche pentru sine qua non, greșită]

* $\varepsilon \nu \delta \varepsilon \chi \jmath_{\mu} \mu v \alpha$ în loc de $\varepsilon \nu \delta \varepsilon \chi 0 \mu \varepsilon^{\prime} \nu \omega \varsigma$

[morfologia adverbului: terminația „demotică” nepotrivită pentru „posibil”]

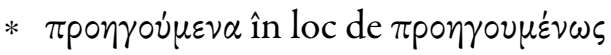

[idem: „anterior”]

* $\pi \alpha \rho \eta^{\prime} \gamma \varepsilon i \lambda \varepsilon$ în loc de $\pi \alpha \rho \dot{\alpha} \gamma \xi \varepsilon 1 \lambda \varepsilon$ (imperative)

[violarea vechii reguli care interzice un acord intern la imperativul aorist:

„dă un ordin”]

* $\varepsilon \xi \dot{\eta} \tau \alpha \sigma \varepsilon$ în loc de $\varepsilon \xi \dot{\xi} \tau \alpha \sigma \varepsilon$

[idem: „examinează”]

* $\quad \alpha \sigma \kappa \omega \dot{~ i ̂ n ~ l o c ~ d e ~} \varepsilon \xi \alpha \sigma \kappa \omega ́$

[frazeologie: confuzie între „a practica” și „a exersa”]

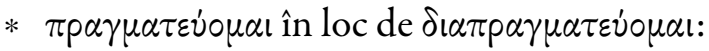

[frazeologie: „a avea de-a face cu” în loc de „a negocia”]

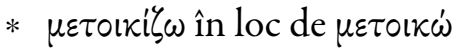

[frazeologie: forma incorectă a cultismului „a-și schimba rezidența”]

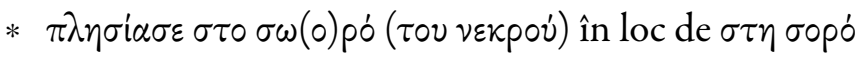

[ortografie: „grămadă, adunătură” în loc de „cadavru”]

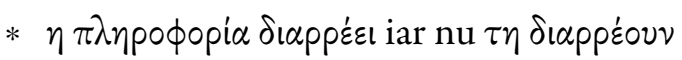

[frazeologie: „informația s-a scurs (intranz.)” iar nu „ei au scurs (tranz.) informația”].

Intrările în index expurgatorius al lui Papakostas prezintă o formă foarte clară:

$X$ [prohibitiv] în loc de Y [normativ],

cu numai o singură schimbare, în ultimul exemplu: 
$\mathrm{Y}$ [normativ] iar nu X [prohibitiv].

Nu este nevoie de explicații. Exemplele vorbesc de la sine. Și sînt extrase dintr-un lot obișnuit. Repertoriul acesta se axează în mod cert pe expresiile achiziţionate, culte. Cele mai multe dintre corectivele-blazon pot fi uşor generalizate ca corective-tip: e.g., variantele înalte, precum sufixul adverbial -os (- $\omega \varsigma)$, nu trebuie vulgarizate; regulile de acord din greaca veche trebuie respectate; expresiile culte nu trebuie modificate; etc. Dintre presupusele greșeli, cele mai multe reprezintă violări ale gramaticii sau frazeologiei arhaice. Desigur, regulilor arhaice li se acordă prioritate în fața regulilor variantei demotice. Firește, că GMS ar trebui să se supună normelor istorice este o „explicativă” pe care este chemat să o formuleze receptorul. Nu este singura explicativă „ascunsă” din repertoriul corectivelor. Mai există și presupoziția comună că devierile de la formele sau sensurile standard nu ar trebui îngăduite; că, pentru a se putea evita proasta exprimare și ambiguitățile, relația dintre formă și funcție ar trebui să fie de 1:1 (sofismul formă-funcție; de observat distincția dintre $\alpha \sigma \varkappa \omega ́$ și $\varepsilon \xi \alpha \sigma \varkappa \omega ́$, care nu reprezintă nici pe departe uzul real); că expresiile trebuie să fie precise și clare; etc. Modelul instrucțiunilor corective este evident lexical-frazeologic. $\mathrm{Cu}$ toate că cele mai multe corectări vizează gramatica și morfologia, abordarea rămîne ancorată în lexic și frazeologie. De exemplu, în cazul primelor două corective-blazon din repertoriul prezentat anterior, nu este necesară formularea normei gramaticale a acordului: normativele implicate ( $\nu \pi \alpha \rho \chi 0 \nu \sigma \omega \dot{\nu} \nu \pi p \circ \beta \lambda \varepsilon \dot{\varepsilon} \psi \varepsilon \omega \nu$ şi $\left.\tau \omega \nu \alpha \nu \alpha \lambda \eta \phi \theta \varepsilon i \sigma \omega^{\prime} \nu \pi \rho \omega \tau 0 \beta 0 \nu \lambda \iota \omega^{\prime} \nu\right)$ ar putea și ar trebui învăţate ca expresii fixe, întocmai cum cere modelul lexical-frazeologic. Acestea, precum și alte presupoziții similare fac ca un anumit repertoriu de corective să capete coerență.

Am examinat pînă acum un repertoriu corectiv care se califică drept exemplu de prescriptivism instituţional. Totuși, s-ar putea tot atît de bine ca acest repertoriu să reflecte alegerile personale ale artizanului său. Pînă la urmă, este posibil ca fiecare vorbitor să aibă propriul lui repertoriu corectiv, după cum își are și propriul idiolect. Dar, pe de altă parte, repertoriile individuale nu pot fi complet diferite unul de celălalt, din motive simple: corectivele sînt, în esență, acte dialogice (un vorbitor A instruiește un vorbitor B să se comporte într-un anumit fel, iar apoi vorbitorul B se comportă potrivit instrucțiunii sau nu); dacă corectivele se aplică ambilor vorbitori, acestea trebuie să fie convenționale. În această privinţă, actele metalingvistice nu diferă de actele lingvistice.

Întrebarea la care trebuie să găsim acum răspuns este dacă nu cumva se conturează un repertoriu supraierarhic ori o tendință predominantă în toate repertoriile existente. Pentru a răspunde, am desfăşurat o analiză cantitativă de corpus asupra tuturor corectivelor care au apărut în articole din presă în decurs de trei luni, între noiembrie 1999 și ianuarie 2000. Corpusul a fost alcătuit prin monitorizarea a 76 de publicații cotidiene și a 102 reviste. Au fost selectate 80 de texte conținînd instrucțiuni corective, dintr-un corpus mai mare, de 364 de texte ce vizau mai multe probleme de limbă (procentajul de texte cu instrucțiuni corective: 22\%). Corpusul a totalizat un număr de 490 de corective (o medie de 6,13/text). Din numărul total de corective, am identificat 328 perechi X/Y (4,1/text), din care 252 erau perechi blazon (3,14/text), iar 76 erau perechi tip $(0,95 /$ text). Pe lîngă perechile X/Y, textele prezentau 162 de corective elipticeX/Ø (2,03/text). O analiză în detaliu se află în Moschonas \& Spitzmüller (2010), unde s-au făcut comparaţii cu un corpus similar de texte din presa germană. Tabela 3 arată o clasificare a corectivelor numai din corpusul grec.

Din moment ce cuvintele reprezintă ținta obișnuită a prescriptivismului, Tabela 3 începe cu corective ce se referă la vocabular. Corectivele din această categorie fac referire la trei tipuri de cuvinte: împrumuturi, arhaisme și cuvinte demotice. Prin arhaisme „marcate” sau forme demotice am vrut să indic acele cuvinte

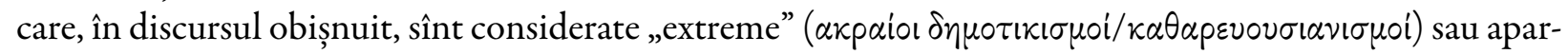
ținînd „limbii de lemn” ( $\xi \dot{\nu} \lambda \iota \nu \eta \gamma \lambda \omega \dot{\sigma} \sigma \sigma \alpha)$. Referirile la cuvintele arhaice și demotice sînt mai numeroase decît cele la cuvintele împrumutate. Se pare că împrumuturile și străinismele încetaseră să fie principala țintă a prescriptivismului, cum se întîmplase în anii '90 (Delveroudi \& Moschonas, 2003; Moschonas, 2001a, 2009). În corpus, toate referirile la împrumuturi (nu doar cuvinte) se ridică la 62 (12,7\%), în timp ce toate referirile la variantele înaltă/inferioară (diglosie), la 158 (32,2\%). Aceste numere sugerează că 


\begin{tabular}{|c|c|c|c|c|c|c|}
\hline & Lexic: & 98 & $(20 \%)$ & Semantică: & 13 & $(2,7 \%)$ \\
\hline \multirow[t]{6}{*}{ cuvinte străine } & & 30 & $(6,1 \%)$ & \multirow{2}{*}{$\begin{array}{l}\text { necunoașterea formelor } \\
\text { culte/arhaice }\end{array}$} & \multirow[t]{2}{*}{7} & \multirow[t]{2}{*}{$(1,4 \%)$} \\
\hline & \multirow{2}{*}{\multicolumn{2}{|c|}{\begin{tabular}{l|} 
împrumuturi din \\
engleză
\end{tabular}}} & $24(4,9 \%)$ & & & \\
\hline & & & & \multirow{2}{*}{$\begin{array}{l}\text { diferențiere sau schimbare } \\
\text { semantică }\end{array}$} & \multirow[t]{2}{*}{6} & \multirow[t]{2}{*}{$\overline{(1,2 \%)}$} \\
\hline & \multirow{2}{*}{\multicolumn{2}{|c|}{$\begin{array}{l}\text { împrumuturi din } \\
\text { alte limbi }\end{array}$}} & $3(0,6 \%)$ & & & \\
\hline & & & & \multirow{2}{*}{ Discurs/Pragmatică: } & 15 & $(3 \%)$ \\
\hline & \multicolumn{2}{|l|}{ calcuri } & $3(0,6 \%)$ & & 13 & \multirow{2}{*}{$\frac{(2,7 \%)}{(0,2 \%)}$} \\
\hline \multicolumn{2}{|c|}{ forme demotice marcate } & 17 & $(3,5 \%)$ & eufemisme & 1 & \\
\hline \multicolumn{2}{|c|}{ forme arhaice marcate } & 38 & $\frac{(7,8 \%)}{(120,1}$ & \multirow[t]{2}{*}{ politețe } & \multirow[t]{2}{*}{1} & \multirow[t]{2}{*}{$(0,2 \%)$} \\
\hline dialectale & & 6 & $(1,2 \%)$ & & & \\
\hline \multicolumn{2}{|l|}{ arhaisme traduse } & 7 & $(1,4 \%)$ & Ortografie: & 75 & \multirow{2}{*}{$\frac{(15,3 \%)}{(1 \%)}$} \\
\hline & \multirow{2}{*}{ razeologie: } & \multirow{2}{*}{29} & \multirow{2}{*}{$\frac{(5,9 \%)}{(120 \alpha)}$} & \multirow{2}{*}{ pro-monotonic } & 5 & \\
\hline & & & & & 4 & $(0,8 \%)$ \\
\hline expresii formula & & 21 & $(4,3 \%)$ & pro-alfabet roman, în unele & 3 & $(0,6 \%)$ \\
\hline$\alpha \phi o p \dot{\alpha} \sigma \varepsilon$ [a privi & fi despre] & 8 & $(1,6 \%)$ & registre & & \\
\hline & fosintaxă: & 199 & $(45,7 \%)$ & contra alfabet roman, peste tot & 10 & $(2 \%)$ \\
\hline violarea unor for & e arhaice & 27 & $(5,5 \%)$ & transliterarea împrumuturilor & 7 & $(1,4 \%)$ \\
\hline acord/atracție & & 12 & $(2,4 \%)$ & regula 'finala $-\nu$ ' (asimilare) & 5 & $(1 \%)$ \\
\hline terminație adv. a & notică $(-\alpha)$ & 29 & $(6 \%)$ & grup CC (disimilare) & 1 & $(0,2 \%)$ \\
\hline schimbarea acce & dlui în & 25 & $(5,1 \%)$ & punctuație & 2 & $(0,4 \%)$ \\
\hline declinare & & & & grafii greșite & 38 & $(7,8 \%)$ \\
\hline afix greșit & & 36 & $(7,3 \%)$ & Miscellanea: & 25 & $(5,1 \%)$ \\
\hline imperativ augme & & 6 & $(1,2 \%)$ & pronunție & 2 & $(0,4 \%)$ \\
\hline prep + propoziți & elativă & 1 & $(0,2 \%)$ & pronunția împrumuturilor & 7 & $(1,4 \%)$ \\
\hline substantive fără & iral/sing. & 60 & $(12,2 \%)$ & pronunția imprumuturilor & 6 & $\frac{(1,4 \%)}{(1,20)}$ \\
\hline adaptori ale împ & muturilor & 25 & $(5,1 \%)$ & $\frac{\text { etimologil false }}{\text { oreceli/acte ratate }}$ & $\begin{array}{r}6 \\
10\end{array}$ & $(1,2 \%)$ \\
\hline compuse mixte & acă-limbă & 2 & $(0,4 \%)$ & greșel1/acte ratate & 10 & $(2 \%)$ \\
\hline
\end{tabular}

străină

\begin{tabular}{lll}
\hline morfologia străină & 1 & $(0,2 \%)$ \\
\hline
\end{tabular}

Tabela 3: Corective în presa grecească nov. 1999 - ian. 2000. Sursa: Moschonas \& Spitzmüller (2010, p. 28-35).

trăim mai degrabă o îngrijorare în privința diglosiei, decît o spaimă puristă față de împrumuturi.

Corectivele din domeniile frazeologiei și morfosintaxei pot fi așezate împreună. 'Morfologie' și 'Sintaxă' $n u$ trebuie luate în sensul lor modern din lingvistica contemporană. 'Morfosintaxă' se referă aici la acea parte din gramatica tradițională care se ocupă mai ales de părțile de vorbire, de conjugare, declinare, derivare și compunere (Tvлikóv), și nu atît cu regulile de formare a propozițiilor. Sintagmele, în sensul tradițional, sînt înțelese, mai mult sau mai puțin, ca îmbinări formulaice construite din unităţi frazeologice. În consecință, nu există o legătură reală între morfosintaxă și frazeologie.

Cele mai multe corective apar în aceste domenii care se suprapun: dacă adăugăm corectivele frazeologice la cele morfologice, obținem un total de 228 (51,6\%); împreună cu corectivele lexicale, ajungem la 326 de corective (mai mult de $70 \%$ din corpus). Creșterea numărului de corective lexical-frazeologice este, după cum am văzut deja, un fenomen relativ recent în evoluția prescriptivismului grec.

Deși 'violarea normelor arhaice' constituie o secțiune separată în Tabela 3, cele mai multe dintre instrucțiunile corective de sub Morfologie/Sintaxă indică o preocupare și pentru corectitudinea formelor arhaice, într-o manieră care aduce aminte de repertoriul lui Papakostas (2006), pe care l-am discutat mai sus. De pildă, fenomenele de acord sau atracție sînt stigmatizate numai în legătură cu formele culte, cum sînt participiile arhaice: $\tau \omega \nu \nu \pi \alpha \rho \chi o ́ v \tau \omega \nu \pi \rho \beta \beta \lambda \varepsilon \dot{\varepsilon} \varepsilon \omega \nu$, „dintre existenții (masc.) predicții (fem.)”. Pentru 
prescriptiviștii care critică normele demotice „extreme”, terminația adverbială demotic - $\alpha$ (' $\alpha \pi \lambda$ - $\alpha$ ' în loc de ' $\left.\alpha \pi \lambda-\omega^{\prime} \varsigma^{\prime}\right)$ este ca un steag roșu în fața unui taur. Mobilitatea accentului în declinare este iarăși măr de discordie în dihotomia katharevousa - demotic, și este normată în concordanță cu regulile arhaice

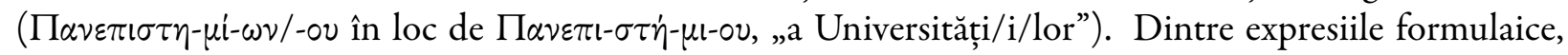
distincția $\alpha \phi \circ \rho \dot{\alpha} \sigma \varepsilon+\mathrm{N}$, „privește N”, vs. $\alpha \phi \circ \rho \dot{\alpha} \tau 0+\mathrm{N}$, ,este despre N”, pare că a devenit o enigmă pentru prescriptiviști, care caută să facă diferența între cele două construcții prin corelări formă - funcție arbitrare (construcția $\alpha \phi \circ p \dot{\alpha} \sigma \varepsilon$ este de fapt un calc intern, bazat pe vechea $\alpha \phi o p \dot{\alpha}+\mathrm{N}$ [dat.]). Trebuie subliniat faptul că variantele lexicale și morfosintactice sînt normate prin convenție, i.e. prin invocarea unor reguli „stricte”, tipice, care reglementează mai cu seamă variantele înalte; din acest motiv, corectivele apar de obicei fără componenta explicativă, ori fac apel la argumentare circulară: „acesta este felul corect de a spune, pentru că felul corect de a spune este acesta”. Exact din acelaşi motiv există numai un număr relativ redus de corective ce vizează semantica, pragmatica sau stilistica expresiilor. După cum a demonstrat Spitzmüller în Moschonas \& Spitzmüller (2010, p. 35-36), opusul îl reprezintă cazul prescriptivismului german contemporan, care „favorizează un topos mai logic (întemeiat pe semantica 'regularizată' a expresiilor și pe o pragmatică 'rigidă’ a uzului lingvistic)".

După cum au subliniat numeroși sociolingviști (Jaffe, 2000; Johnson, 2005; Sebba, 2007; cf. Jaffe et al., 2012), ortografia este percepută ca parte integrantă a limbii, chiar dacă teoriile lingvistice moderne au acordat o oarecare prioritate vorbirii, în detrimentul scrierii. În Grecia, discuțiile relevante se concentrează asupra a două tipuri de variație: 1 . Variaţie în interiorul ortografiei grecești (scriere monotonică vs. politonică); 2. Variație în privința scrisului non-grecesc (folosirea alfabetului grecesc vs. roman; v. Androutsopoulos, 2001, 2009). În eșantionul de corpus cercetat de mine, există 5 ocurențe ale tipului $\mathrm{X} / \mathrm{Y}$ în favoarea sistemului monotonic vs. 4 contra lui. Există numai 3 mențiuni care legitimează scrisul cu caractere romane în unele specii (e-mail-ul, de exemplu) vs. 10 care sînt împotriva scrisului cu caractere roman, în orice registru.

Să facem un rezumat a ceea ce am discutat pînă acum. Am văzut că GMS se bazează, în principiu, pe varianta demotică, cu unele concesii, totuși, față de un număr oarecare de arhaisme și cultisme, mai ales în registrele înalte ale limbii, urmînd formula de standardizare a lui Triantaphyllidis: 'GMS = demotic + forme culte (în măsura în care este nevoie)'. Am văzut, de asemenea, că formele vernaculare (variantele inferioare) au devenit treptat norme și s-au „naturalizat”: au devenit limba vorbită (și scrisă?) „în mod natural/spontan” de către „vorbitorii nativi”. Nevoie de instrucțiuni corective au acum variantele arhaice, culte. Pentru a se ocupa de ele, a fost concept un model lexical-frazeologic, unul care tratează cuvintele şi construcțiile în mod individual, izolate, pe măsură ce se ivește nevoia. Aceste variante de cuvinte și construcții nu fac parte dintr-un sistem „uniform”- tocmai pentru că Standardul nu este caracterizat de uniformitate. Noul model corectiv pune accentul pe frazeologie și idiomatic, indiferent de orice diferențe morfologice care ar exista între demotic și katharevousa. Modelul lexical-frazeologic care corespunde normelor „mixte” ale GMS este convențional în rațiunea lui de a fi, i.e. se întemeiază pe arbitraritatea și pe obligativitatea formelor lexicale și ale construcțiilor sintactice. În sfîrşit, în Standardul contemporan, purismul este mai degrabă intern decît extern, i.e. este preocupat de împrumuturile interne, mai degrabă decît de cele externe-cele interne fiind împrumuturile din greaca veche sau din varietățile tipului katharevousa (Moschonas, 2010, p. 35). Această preocupare față de împrumuturile interne este, desigur, caracteristică pentru atitudinea purismului, și nu pentru practica lui reală. În ciuda lipsei unor studii temeinice, mi se pare rezonabilă ipoteza că purismul extern este practicat acum la scară largă, avînd succes mai ales în cîmpul terminologiei tehnice. Poate că tocmai succesul practicii puriste a făcut ca atitudinea puristă să se diminueze în discursul metalingvistic. Vom reveni asupra acestui fenomen (conștientizarea colectivă a unei practici lingvistice se estompează tocmai în momentul în care aceasta devine colectivă), atunci cînd vom analiza cîteva dintre studiile recente ce s-au ocupat de efectele prescriptivismului asupra schimbării lingvistice, în secțiunea de Concluzii și discuții. 


\section{Ideologie}

Limbii standard i se asociază adesea ideea de 'neutralitate'. Neutralitatea este gîndită de obicei în termeni geografici și este aplicată mai bine în relație cu accentul. Potrivit lui Henry Sweet, fonetician și gramatician englez, „cei mai buni vorbitori ai englezei standard sînt cei a căror pronunție, și limbă, în general, le trădează cel mai puțin originea” (apud Mugglestone, 2003, p. 4; cf. Jespersen, 1964, p. 61, care pare să fi exprimat un punct de vedere similar nu mai tîrziu de 1890) ${ }^{9}$.

Un accent care să ascundă aspecte ale identității unui vorbitor este, desigur, posibil, dar el nu poate fi descris în niciun caz ca „neutru”, deoarece dezvăluie alte aspecte ale aceleiași identități (inclusiv faptul că vorbitorul caută să-şi ascundă originea). Nu ne ia mult să ne dăm seama că ideea de neutralitate accentuală este absurdă la un nivel chiar mai elementar. Este asemeni pretenției că un accent corect este de fapt lipsa unui accent—este „fără de accent” (Mugglestone, 2003, p. 40, 46)—fie în privința proprietăților, fie a implicațiilor sale pentru vorbitor. Nu există însă o varietate fără accent. Un 'accent neutru' se reduce la un fenomen perceptual sau atitudinal, care nu caracterizează o limbă standard. În măsura în care accentele sînt mărci de clasă socială, ideea de 'neutralitate accentuală poate fi dezavuată ca ideologică, preconcepută, discriminatorie (cf. Crowley, 1989, cap. 6), chiar şovinistă ori rasistă. Dar acesta ar fi un caz de critică excesivă care ar rata esențialul: nu există accent neutru, pentru că nu există accent fără de accent.

'Neutralitatea' (i.e., atitudinea faţă de Standard) nu se aplică numai accentelor; este parte componentă a ideologiei unei limbi standard ca întreg. Din nou, mă refer aici numai la GMS. Triantaphyllidis (1963, p. 181-187), întemeietorul GMS, a admis că a sa Koine, cea la normarea căreia a contribuit în așa mare măsură, a fost strîns asociată cu naționalismul, dar a refuzat să o identifice cu orice alte ideologii implicate în polemica legată de „Chestiunea limbii”, mai ales cu cele stigmatizate de elitele clasei politice conducătoare din vremea sa (comunismul, socialismul, slavismul, ateismul...). Scrierea unei Gramatici a variantei demotice fusese o însărcinare dată lui Triantaphyllidis et al. (1978) de către regimul fascist (Mackridge, 2009, p. 301). Ceea ce constituie o problemă pentru susţinătorii lui Triantaphyllidis. Dar dacă un Standard este „ideologic neutru”, atunci ar trebui să fie neutru față de orice ideologie, inclusiv față de cea fascistă. Această de-ideologizare a Normei este pe același plan cu neutralizarea unui accent. Întocmai cum neutralitatea accentuală presupune că vorbitorilor unei limbi standard nu li se poate identifica originea locală (Crowley, 1989, p. 186), și de-ideologizarea, i.e. 'neutralitatea ideologică', ar trebui să presupună că vorbitorilor nu li se poate identifica ideologia preferată. (Să nu uităm însă: de-ideologizarea nu este decît o altă ideologie, poate cea dominantă; tot aşa cum un ,accent neutru” nu este decît un alt accent, cel standard.)

În studiul care urmează voi avea în vedere un grup de variabile morfofonologice ale căror variante înaltă/inferioară au fost îndeaproape asociate cu ruptura katharevousa/demotic a diglosiei. Variabilele fuseseră stereotipice, pline de implicații politice; uzul fiecărei variante semnalizase nu doar convingerea vorbitorului despre limbă, ci și afilierea politică a acestuia. Studiul arată că semnificațiile sociale ale respectivelor variante s-au schimbat considerabil între timp, în era post-diglosie. Variantele au fost „neutralizate”: nu mai sînt asociate cu ideologii politice, nu sînt constrînse politic. Prin urmare, variabilele selectate oferă dovada pentru recent-obţinuta „neutralitate a normei/standardului”.

În Studiul 3 privim la evoluția „neutralității ideologice” ca pre-condiție a ceea ce, în secțiunea următoare, vom numi 'stilizare', i.e. expansiunea alegerilor stilistice pe seama celor ideologice. În secțiunea care urmează acesteia (4) vom indentifica încă o variabilă „neutră”, una care nu a fost asociată cu diglosia, deși a fost întotdeauna subiect al prescriptivismului, și vom urmări cum este implicată stilistic în media.

Dar mai întîi, studiul asupra de-ideologizării:

\footnotetext{
${ }^{9}$ De fapt, idea unei neutralități geografice și a unei norme non-locale, non-dialectale este mult mai veche; poate fi urmărită înapoi pînă la Dante, De Vulgari Eloquentia, compusă între 1302 și 1305; poetul italian pledează acolo pentru existența ori nevoia unui standard diferit de toate varietățile locale (Ewert, 1940, p. 363); v. Crowley (1989, p. 129 ff., 186), Mugglestone (2003, p. 7 ff., 258), în privința istoriei limbii engleze; cf. Rutten (2016) pentru o discuție generală despre situația olandezei.
} 


\section{Study 3: Variație morfologică în presa grecească}

Variația morfologică datorată diglosiei a fost considerată un indicator al diferențierii ideologice și/sau stilistice în presa grecească. Din nefericire, studiile lingvistice relevante par să fie mai degrabă intuitive și nu furnizează rezultate cantitative. În literatura de specialitate, abia dacă s-au formulat două explicații pentru variația morfofonologică din presă: Chatzissavidis (1999a,b, 2000) pare convins că variabilele lingvistice se asociază strîns cu afilierea politică a ziarelor, o afiliere pe care cercetătorul o consideră de la sine înțeleasă; abordarea lui nu se întemeiază pe vreun corpus și nu oferă date statistice. Iordanidou (2001a, 2009), pe de altă parte, își asumă o abordare valoroasă, bazată pe corpus, și ajunge la următoarele concluzii: o considerabilă variație morfofonologică poate fi detectată la nivelul aceleiași publicații, la nivelul publicațiilor aparținînd aceleiași culori politice (mai ales în cazul celor de centru), chiar și la nivelul aceluiași articol; variația morfofonologică poate fi numai parțial justificată de considerente stilistice.

Amintesc aici de Kolia et al. (2013), o cercetare realizată de studenți, pe care am supravegheat-o. Kolia et al. (2013) furnizează o analiză statistică elementară a variației morfofonologice în presa grecească, ce dovedește în mod suficient că a) nu se poate stabili o conexiune strînsă între uzul variantelor înalte/inferioare şi ideologia unui ziar grec, și b) se poate stabili o uşoară corelație între variantele morfofonologice și un factor stilistic, genul unui text publicistic, dar ea nu este semnificativă statistic.

Cercetarea respectivă a fost desfășurată în săptămîna 14-22 noiembrie 2009. Au fost selectate șase (6)

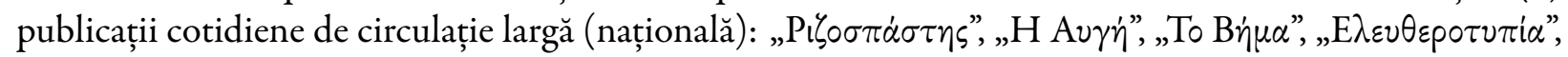

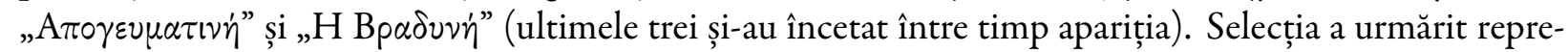
zentarea echitabilă a spectrului politic al vremii, de Stînga, Centru și Dreapta. Afilierea politică a fiecărui

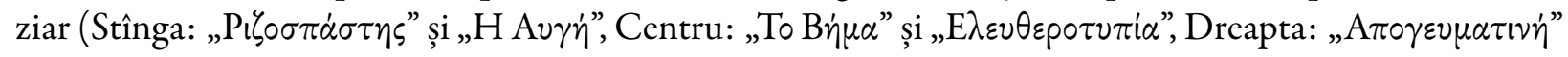
şi "Bp $\alpha \delta \nu v \eta ”$ ") s-a realizat pe criterii independente care au impus validări separate (a fost alcătuit un indice complex care a avut în vedere: punctul de vedere exprimat de editor, auto-identificarea jurnaliștilor principali în fiecare publicație, spațiul publicistic rezervat partidelor politice și alți cîțiva factori).

Variabilele lingvistice studiate au fost următoarele (în cadrul fiecărei perechi, prima variantă se consideră a fi inferioară/demotică, iar cea de-a doua, corespunzătoare, înaltă/arhaică):

1. variație a grupurilor consonantice în baza aoristului pasiv; e.g., fricativă-oclusivă: $-\chi \tau-/-\phi \tau-/-\sigma \tau-$ vs. fricativă-fricativă: $-\chi \theta-/-\phi \theta-/-\sigma \theta-$ în forme precum $\{0 p i-\sigma \tau-\eta \kappa \varepsilon, o p i-\sigma \theta-\eta \kappa \varepsilon\},, s-a$ numit/definit”;

2. variație similară în grupuri consonantice ale formelor lexicale independente, e.g $\{\chi \tau \varepsilon \varsigma, \chi \theta \varepsilon \varsigma\}$, ,ieri” ${ }^{10}$;

3. persoana a treia sing./pl. a aoristului pasiv $\{-\eta \kappa \alpha /-\eta \kappa \alpha \nu,-\eta /-\eta \sigma \alpha \nu\}$ în perechi de cuvinte precum $\{\kappa \lambda \dot{\alpha} \pi-$ $\eta \kappa \alpha \nu,(\varepsilon) \kappa \lambda \dot{\alpha} \pi-\eta \sigma \alpha \nu\}$, ,s-au furat”;

4. terminațiile adverbiale $\{-\alpha,-\omega s\}$ în cuvinte precum $\left\{\alpha \pi \lambda-\dot{\alpha}, \alpha \pi \lambda-\omega^{\prime} \varsigma\right\}$, ,simplu” ${ }^{11}$;

5. variaţia accentului la formele de genitiv sing./pl. ale substantivelor și adjectivelor; e.g., $\{\varepsilon \gamma \kappa \dot{v} \kappa \lambda ı$, $\varepsilon \gamma \kappa \nu \kappa \lambda i ́ o v\}$, ,circular”, $\{\delta \eta \mu o ́ \sigma i \omega \nu, \delta \eta \mu \circ \sigma i \omega \nu\}$, ,public”.

6. genitivul masculin sing. $\{-\alpha,-\delta s\}$ în cuvinte precum $\{\mu \dot{\eta} \nu-\alpha, \mu \eta \nu-o ́ s\}$, ,lună [calendaristică, n.tr.]”.

7. genitivul masculin sing. $\{-\varepsilon \alpha,-\dot{\varepsilon} \omega \varsigma\}$ în cuvinte precum $\{\varepsilon|\sigma \alpha \gamma \gamma \varepsilon \lambda-\dot{\varepsilon} \alpha, \varepsilon| \sigma \alpha \gamma \gamma \varepsilon \lambda-\dot{\varepsilon} \omega \varsigma\}$, „procuror”;

8. genitivul masculin sing. $\{-\dot{\eta},-\circ \dot{v} \varsigma\}$ în adjective precum $\{\alpha \delta \alpha-\dot{\eta}, \alpha \delta \alpha$-ov's\}, ,ignorant, naiv”.

În sfîrșit, o ultimă variabilă lingvistică a fost luată în considerare, una care, suficient de surprinzător, și-a pierdut între timp complet forţa discriminatorie:

9. variația terminațiilor de genitiv feminin $\{-\eta \varsigma,-\varepsilon \omega \varsigma\}$ ale așa-numitei „declinări a treia” a substantivelor; e.g., $\{\kappa \nu \beta \varepsilon \dot{\varepsilon} \nu \nu \eta \sigma-\eta \varsigma, \kappa \nu \beta \varepsilon p \nu \eta \dot{\sigma} \sigma-\varepsilon \omega s\}$, ,guvern”.

Această ultimă variabilă are o oarecare semnificație istorică. După reforma lingvistică din 1976, a căpătat curînd statutul unui „stereotip” (în sensul lui Labov, 1972, p. 314); s-a crezut că alegerea uneia sau alteia dintre variante indica în mod clar afilierea politică a vorbitorului. La momentul în care se desfășura

\footnotetext{
${ }^{10}$ Cele două variabile de mai sus au fost studiate independent de Mikros et al. (1996), care au descoperit numai o ușoară corelație cu genul/specia textelor (s-au avut în vedere trei tipuri de texte: oficiale, jurnalistice și artistice).

${ }^{11} \mathrm{Nu}$ s-a ținut cont de cazurile în care fiecare variantă se presupune că se asociază cu un sens diferit, în concordanță cu perechea formă - funcție; e.g. $\alpha \mu \varepsilon \sigma \alpha$, „direct”, and $\alpha \mu \dot{\varepsilon} \sigma \omega \varsigma$, ,imediat”.
} 
cercetarea (2009), varianta demotică, non-arhaică părea să fi prevalat asupra - $\varepsilon \omega \varsigma$ (numai 2/354 cazuri de

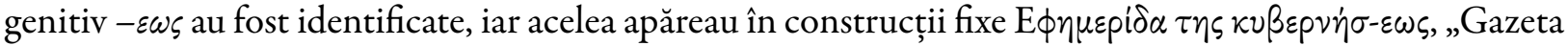
Oficială a Guvernului”, and $\pi \dot{\alpha} \sigma \eta \varsigma \phi \dot{\sigma} \sigma \varepsilon \omega \varsigma$, „de toate felurile”). Din acest motiv, nu am arătat rezultatele obținute pentru această variabilă. Omiterea acestei variabile nu trebuie să dea de înțeles că varianta - $\varepsilon \omega \varsigma$ nu ar apărea nici într-un corpus mai larg, conținînd, e.g., documente juridice.

Au fost testate două ipoteze de lucru: 1. Numărul variantelor morfologice arhaice, culte ar trebui să crească pe măsură ce ne deplasăm, ca să spunem astfel, de la Stînga, spre Dreapta spectrului publicistic; 2. Variantele arhaice ar trebui de asemenea să sporească odată cu formalitatea asociată speciei publicistice, presupunînd următoarea ierarhie: comentarii și notițe ( $\pi \alpha \rho \alpha \pi \circ \lambda ı \tau ı k \alpha$ : texte scurte, cu precădere satirice) $\rightarrow$ articole $\rightarrow$ editoriale. Combinînd cele două ipoteze, numărul variantelor morfofonologice culte ar trebui să crească dublu-vectorial: Stînga $\rightarrow$ Centru $\rightarrow$ Dreapta (ipoteza 1) și: Comentariu $\rightarrow$ Articol $\rightarrow$ Editorial (ipoteza 2).

Niciuna dintre aceste ipoteze nu a fost confirmată; nici interacțiunea dintre cei doi factori (afilierea politică și genul) nu a furnizat rezultate semnificativ satisfăcătoare. Rezultatele apar în Fig. 5a. Nu s-a

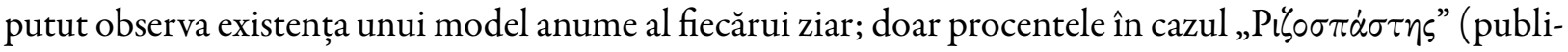
caţie a Partidului Comunist Grec) par să fie mai scăzute în raport cu cele ale celorlalte publicaţii. Fig. 5b indică procentajele variantelor înalte/inferioare nu pentru fiecare ziar, ci pentru fiecare afiliere politică; diagramele pentru afilierea politică sînt calculate ca procentaje a două publicaţii: Stînga = „Pi

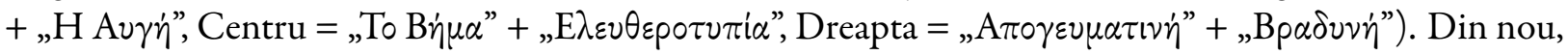
cotidienele de Stînga sînt caracterizate de procentaje mai mici în privința variantelor înalte/inferioare, în timp ce procentajele cotidienelor de Centru sînt mai ridicate decît cele ale ziarelor de Dreapta-contrar așteptărilor. Astfel, ipoteza 1 trebuie respinsă.

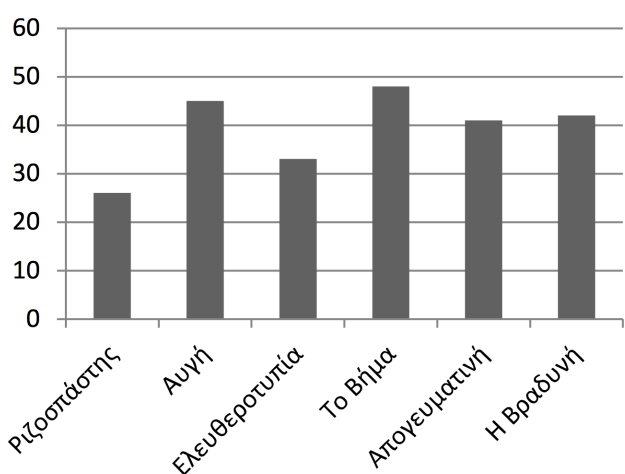

(a) Procentaje ale variantelor culte/înalte în șase publicații grecești.

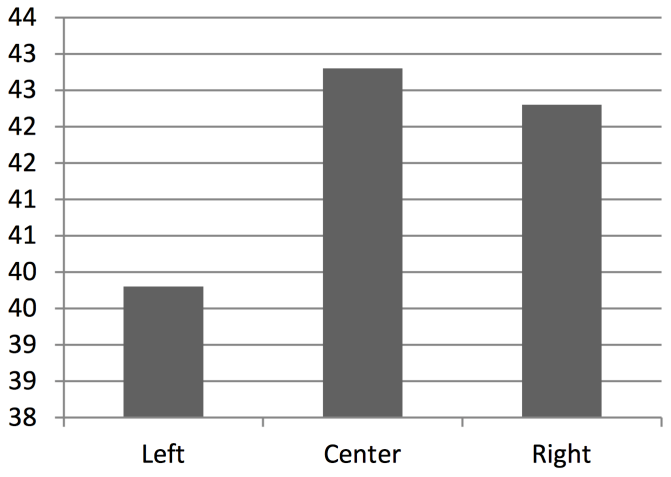

(b) Procentaje ale variantelor culte/înalte după afilierea politică a ziarelor grecești.

Figura 5: Procentaje ale variantelor culte/înalte în publicații grecești. Sursa: Kolia et al. (2013, p. 145).

În Fig. 6a, procentajele variantelor înalte/inferioare sînt prezentate pentru fiecare ziar și pentru fiecare specie (editorial - articol - comentariu). Există, se pare, o ușoară corelare cu specia, fapt mai evident dacă grupăm publicațiile în funcție de afilierea lor politică, cum am procedat și mai sus: v. Fig. 6b, cu rezultatele combinate în funcție de afiliere. Numărul variantelor înalte/inferioare variază în funcție de treapta formală: Comentariu $\rightarrow$ Articol $\rightarrow$ Editorial (ipoteza 2). Rezultatele nu sînt însă statistic semnificative și nu permit vreo generalizare fermă în privința modului în care variabilele lingvistice selectate ar fi folosite cu intenție stilistică în presa greacă.

În concluzie, uzul variantelor înalte/inferioare nu se corelează semnificativ nici cu adeziunea politică declarată a ziarului, nici cu presupusa formalitate/neformalitate a genurilor gazetărești. Opinia lui Chatzissavidis (1999a,b, 2000) că s-ar manifesta o ideologizare politică a variației diglosice trebuie respinsă; totuşi, pentru că cercetarea s-a desfășurat în 1997-1998, s-ar putea ca ea să fi oglindit un stadiu timpuriu 


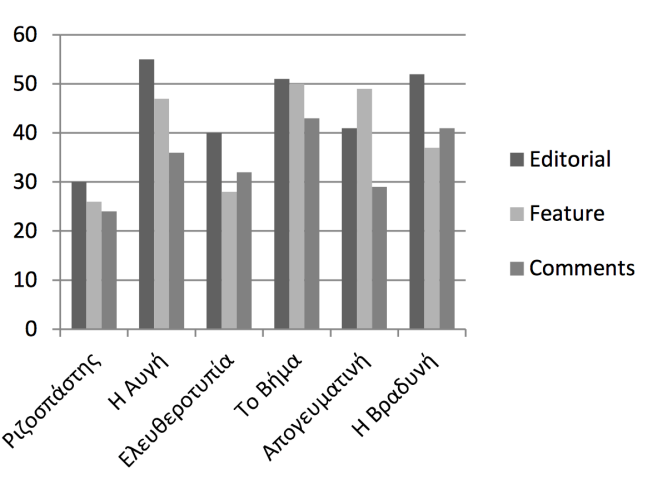

(a) Procentaje ale variantelor culte/înalte după publicație și specie.

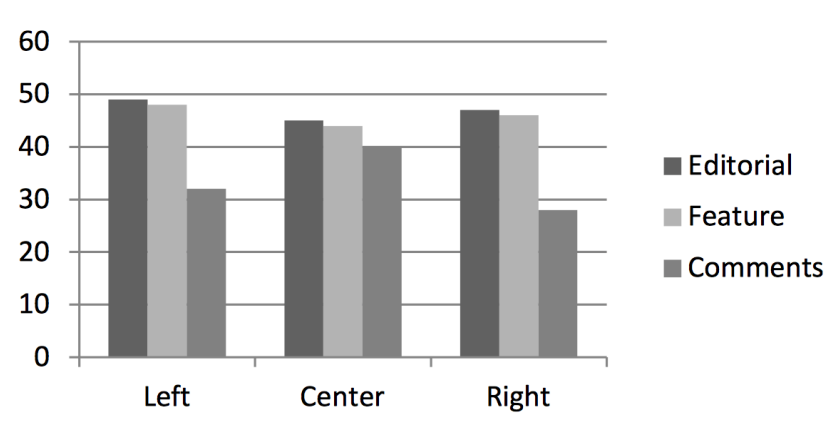

(b) Procentaje ale variantelor culte/înalte după afilierea politică și specie.

Figura 6: Procentaje ale variantelor culte/înalte în publicații grecești. Sursa: Kolia et al. (2013, p. 148).

în viața socială a variantelor înalte/inferioare. Este bine să subliniem și faptul că Chatzisavvidis luase în considerare un set de variabile ușor diferit. Pe de altă parte, Iordanidou (2001a, 2009) au dreptate să sublinieze că o considerabilă variaţie morfologică poate fi observată chiar în cuprinsul aceluiași spectru publicistic, ca să spunem așa, ce include publicații și de Centru, și de Dreapta. Din existența unei variații considerabile în interiorul și de-a lungul unui spectru politic, sîntem îndreptățiţi să concluzionăm că mărcile morfologice majore ale variantei katharevousa au încetat să fie un indicator al ideologiei politice „conservatoare”, cu toate că unele dintre mărcile morfologice majore ale variantei demotice se poate să indice o auto-proclamată ideologie „progresivă” (asociată probabil cu unele dintre mai radicalele varietăți ale Stîngii). În sfîrșit, factorul stilistic influențează prea puțin utilizarea variantelor înalte/inferioare.

Variabilele lingvistice pe care le-am discutat în studiul nostru par a cunoaște un proces de „neutralizare”, de de-ideologizare, fără a fi, în același timp, supuse unei intense variaţii stilistice. Cel puțin, aceasta pare să fie situația din marile publicații de limbă greacă. Am precizat deja că neutralitatea este un factor atitudinal. Este parte a ideologiei lingvistice care înconjoară un Standard. Dar, din moment ce, în studiul nostru, acest factor atitudinal era mediat (corpusul pe care ne-am bazat este o mostră semnificativă de publicistică grecească de toate culorile politice), se poate considera că a afectat sau că a fost afectat de uzul limbii in media. Un proces ideologic, anume de-ideologizarea normelor, pare să afecteze sau să fi fost afectat de schimbările suferite de Standardul însuşi.

În această secțiune am privit de-ideologizarea ca o precondiţie a evoluției variației stilistice. În următoarea secțiune, ultima, a acestei lucrări vom vedea cum devine obiect al variației stilistice o variabilă „neutră” din punct de vedere ideologic. Dovezile pe care le avem la dispoziție sînt mai degrabă modeste, dar confirmă ipoteza că de-ideologizarea este o precondiție a stilizării. (Nu formulez aici o maximă sociolingvistică de uz general; încerc doar să explic un accident apărut în procesul continuu de standardizare a limbii grecești moderne).

\section{Stil}

Unii lingviști ar pune semnul de egalitate între o varietate standard și unele resurse stilistice oferite de limbă. Tot astfel, ar considera re-standardizarea sau de-standardizarea ca realocare a acestor resurse. Agha (2007) concepe limbile standard ca registre. Și pare să înțeleagă prin standardizare un fenomen perceptual, limitat la „modele reflexive de uz”, și reprodus prin "practici metadiscursive” (Agha, 2007, p. 6, 125, 191, 193, 199, 206-219, 228) - o viziune destul de asemănătoare cu perspectiva (b), din Introducerea la articolul de față. Cu o abordare mai realistă, vin recent Thøgersen, Coupland \& Mortensen (2016) și Mortensen, Coupland \& Thøgersen (2017), adoptînd explicit viziunea potrivit căreia standardizarea (sau de-, sau re-standardizarea) este „stilizare”; mai multe studii din cele două volume pomenite explorează 
efectele pe care le au medierea și stilizarea asupra schimbării lingvistice.

Voi rămîne la termenul 'stilizare', pe care nu voi încerca să-l definesc. Pentru nevoile argumentaţiei mele, este suficientă oricare dintre definițiile 'stilului', cu care operează sociolingvistica variaționistă clasică; diferențele de stil sînt date de diferențele de gen (e.g., discurs pre-scris/lucrat vs. discurs spontan/liber), grad de formalitate și concentrare (e.g., citirea cuvintelor vs. citirea pasajelor vs. participare la conversații informale), situație (formal vs. informal) etc. În studiul care urmează voi folosi variabila independentă 'discurs pre-scris vs. discurs liber' ca indicator al stilului.

În secțiunea anterioară am examinat procesul de-ideologizării, i.e. formarea unei atitudini dominante cu privire la Standard, prin care unui Standard i se stabilesc calitățile: „natural”, „neutru”, „nediferențiator”. De-ideologizarea este un mecanism auto-înșelător; constă în ignorarea (aproape) totală a variației, prin pierderea din vedere a asocierilor deictice ale variantelor. Prefer să văd în 'neutralizare' un mecanism inş̦elător, dar cineva se poate gîndi la el, în termeni ceva mai neutri, ca la o convingere colectivă despre o limbă standard. Mulți observatori competenți ai limbii, cum sînt lingviștii, mai ales cei preocupați de chiar procesul standardizării, împărtășesc această convingere cu vorbitorii obișnuiți, nesiguri pe limba standard pe care o folosesc și care, în consecință, se întreabă temători „Vorbesc cu accent?”. Vorbitorul obișnuit presupune că standardul este neutru; observatorul instruit teoretizează această neutralitate. De-ideologizarea joacă feste și vorbitorului obișnuit, și teoreticianului. Cînd se decretează „neutralitatea”, noile generații de vorbitori sînt condiționați să nu mai observe variația care fusese evidentă pentru generațiile precursoare și care, în cazul diglosiei, ar fi fost vitalizată prin mijlocirea discursurilor metalingvistice concurente.

Ipoteza noastră era că stilizarea se dezvoltă numai după ce se produce de-ideologizarea și că aceasta din urmă este o precondiție a celei dintîi. Pentru ca vorbitorii să creeze repertorii stilistice, este necesar să nu fie constrînși de ideologie sau de ceea ce ei ar putea percepe ca fiind ideologie. Nu putem spera să confirmăm ipoteza că există o relație cauzală între de-ideologizare și stilizare; verificarea ei necesită un efort comparativ care ne depășește. Dar pare a fi o ipoteză rezonabilă pentru situațiile de după perioada caracterizată de diglosie. O vom ilustra aici cu un exemplu: un studiu asupra variabilei fonologice a prenazalizării consoanelor oclusive sonore în vorbirea din media.

\section{Study 4: Nazalizarea în vorbirea din media}

Variabila examinată aici este prenazalizarea consoanelor oclusive sonore. Există două variante de pronunțare a unei consoane: [b, d, g] și [mb, nd, ng] (nu ne vom ocupa aici de fenomenul similar care privește oclusivele surde, [mp, nt, $\mathrm{nk}$ ]; de asemenea, lăsăm la o parte prenazalizarea în relație cu fenomenul de sandhi).

Nazalizarea propriu-zisă a consoanelor oclusive sonore a reprezentat dintotdeauna o preocupare a prescriptiviștilor. Cu toate acestea, după cîte știu, variabila fonologică nu a fost asociată cu niciuna dintre grupările ideologice ale „Chestiunii limbii grecești”; așadar, cel puțin în această privință, poate fi considerată de-ideologizată. Triantaphyllidis, cu permisivitatea sa caracteristică, menționează ambele variante în Gramatica sa (Triantaphyllidis et al. (1978), p. 35 \$72). Și este o coincidență fericită că nazalizarea oclusivelor a fost meticulos studiată de către sociolingviștii greci; s-a creat deci o imagine cît se poate de clară a acestui fenomen fonologic, ce poate fi acum pusă în contrast cu „regula” prescriptivistă.

Dar mai întîi să privim la „regula” prescriptivistă, la corectivă. Toate manualele de exersare a pronunţiei pe care le-am frunzărit sînt unanime în privința modalității în care ar trebui normată nazalizarea (cel mai recent îndreptar consultat de mine este Sifonios, 2017, p. 20-31, adresat profesioniștilor din media și din comunicare). „Regula” prescriptivă pare să fie larg răspîndită. Nazalizarea oclusivelor sonore a făcut obiectul a numeroase scrisori către editor, cu denunțări ale pronunției incorecte a multor crainici radio-tv. Fragmentul care urmează este extras din Lypourlis (1994, p. 33-36) —un îndreptar pe care l-am menționat mai sus, în secțiunea 2; sfatul lui Lypourlis este adresat „publicului larg”:

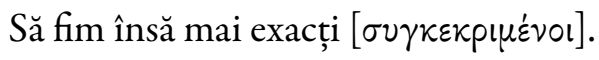


În cuvîntul pe care l-am folosit acum, crainicul nostru de televiziune-și nu este nicio îndoială în

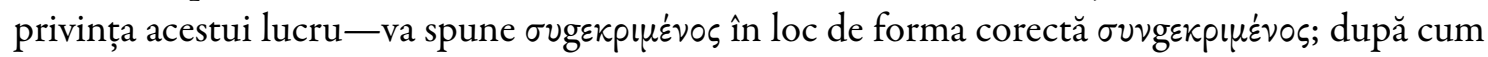

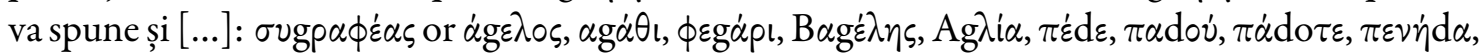

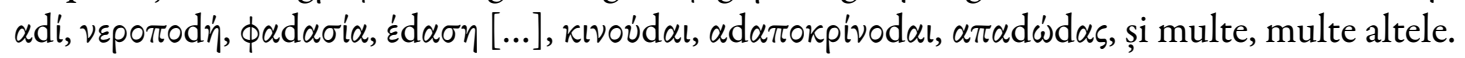

[...] Există deci vreo regulă care să ne învețe care, în fiecare caz, este modalitatea corectă de pronunțare a acestor cuvinte? Bineînțeles că există. Să urmăm regula, atunci:

Sunetele $\{\mu \pi\}(=\mathrm{b}),\{\gamma \kappa\}(=\mathrm{g}),\{v \tau\}(=\mathrm{d})$ - spune regula-se pronunţă fără niciun sunet nazal

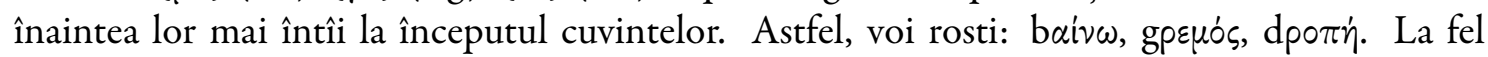
voi pronunța aceste sunete și în interiorul cuvîntului - atenție! - după o consoană. Astfel: bápbas, apgó, kabapdiva. La fel voi pronunța aceste sunete în interiorul unui cuvînt și între

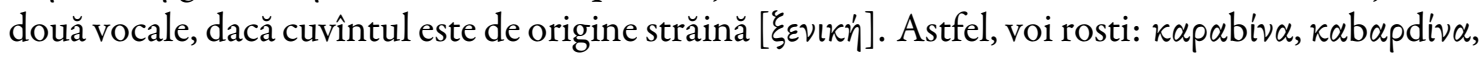

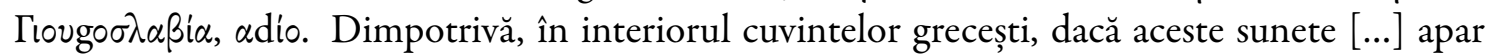
între două vocale, pronunția lor se face în aşa fel încît se aude un sunet nazal înaintea lor. Astfel,

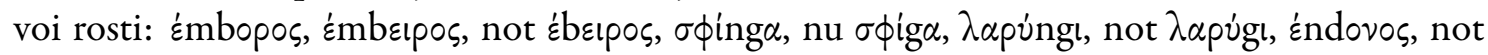
ह́dovos, etc. etc.

[...] Cînd aducem în limbă cuvinte străine [...], trebuie să fim atenți și să le pronunțăm [...] aşa cum se pronunță în limba din care le împrumutăm. Astfel, ar trebui să spunem $\beta$ ídeo, cum

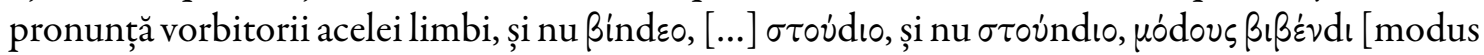

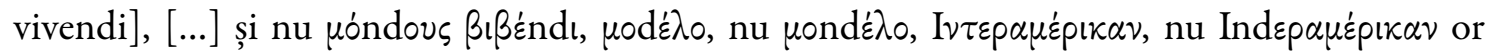
$\operatorname{Id} \varepsilon p \alpha \mu \dot{p} \operatorname{ik\alpha \nu }[\ldots]$

[...] este oare atît de neimportant pentru noi să învățăm să nu ne facem de rîs în fața altora pronunţîndu-le sau scriindu-le cuvintele după cum ne taie capul?

Că avem de-a face cu o regulă prescriptivă putem să ne dăm seama din chiar faptul că sînt menționate ambele variante, dar numai una este judecată drept potrivită. Există o parte prohibitivă și una normativă în formulare, precum și condiții care specifică care e una și care, cealaltă. Este remarcabil cît de complicate sînt aceste condiții; doi factori trebuie avuți în vedere: vecinătățile fonologice (\#_, C_, V__ V) și originea cuvîntului (greacă vs. străină); cei doi factori interacționează în mediul $V_{-} \_$V. Originea cuvîntului este și ea invocată pentru a justifica o atitudine puristă inversă: cuvintele grecești trebuie pronunțate în manieră grecească, cele străine, în maniera limbii lor de origine. Acest din urmă factor, originea cuvintului, presupune aplicarea unor considerabile cunoștințe metalingvistice (i.e., cunoștințe despre etimologia cuvintelor), care nu putem avea pretenția să existe în bagajul unui vorbitor obişnuit al limbii noastre; doar specialiștii în studiul limbii au acces la informația metalingvistică. Accesul redus la cunoștințele metalingvistice și complexitatea generală a prescriptivei în discuție sugerează că regula se adresează în primul rînd vorbitorilor care, aplicînd-o, ar urmări ceva ce Bourdieu (1991) ar numi „distincție simbolică”. $\mathrm{Cu}$ alte cuvinte, regula nu poate fi accesibilă vorbitorului de rînd. Atragem atenția și asupra tonului acuzator din remarcile introductive ale lui Lupourlis: Lypourlis se arată preocupat de discursul public și îi dojenește pe profesioniștii din media pentru uzul lor lingvistic (despre cum a ajuns uzul din media să fie ținta prescriptivismului, v. Moschonas, 2014).

Regula prescriptivă nu corespunde cu uzul real, dar s-ar putea să fi influențat comportamentul lingvistic al unor categorii profesionale ca actorii sau crainicii radio-tv. Prenazalizarea oclusivelor este o variabilă intens studiată în sociolingvistica grecească (v., printre altele: Pagoni, 1990, 1991, 1993; Charalabopoulos et al., 1992; Mikros, 1997, 1999, 2008; Arvaniti \& Joseph, 2000). Ne sprijinim pe Arvaniti \& Joseph (2000), care demonstrează convingător că „vîrsta, nu stilul, constituie factorul esenţial” în variaţia oclusivelor sonore prenazalizate. Fig. 7 arată gradul de nazalizare a oclusivelor în poziție medială în cuvînt, pe trei grupe de vîrstă $(17-30,31-45,46-71)$, testarea desfăşurîndu-se în două circumstanțe distincte (citirea unui text vs. participarea la o conversație). Cele mai mici două grupe de vîrstă prezintă același comportament: un procentaj foarte scăzut de prenazalizare, atît la citire, cît și la conversaţie, în vreme ce vorbitorii din grupa de vîrstă 46-71 nazalizează semnificativ mai mult în ambele circumstanțe, producînd 


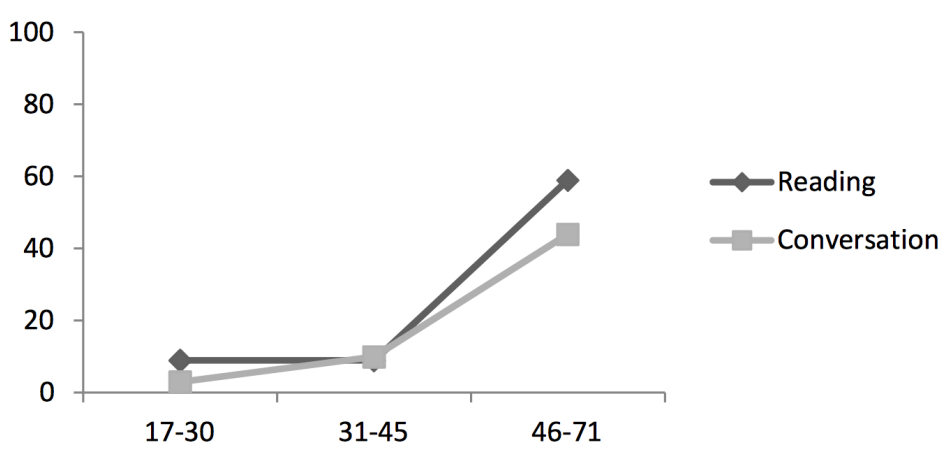

Figura 7: Procentaje ale prenazalizării oclusivelor sonore în poziție medială în cuvînt, după stil și vîrstă. Sursa: Arvaniti \& Joseph (2000, p. 146).

diferențe semnificative și între citire și conversație (Arvaniti \& Joseph, 2000, p. 145-146). În literatura de specialitate mai sînt luați în considerare și alți factori care ar putea afecta nazalizarea (e.g., factori contextuali precum poziția inițială vs. medială în cuvînt, poziția post-consonantică vs. intervocalică, poziții sandhi; tempoul vorbirii, profesia, gradul de educaţie, regiunea etc.; v. mai ales Mikros, 1997, pentru factori legați de vorbirea la radio). Nu vom împovăra prezentarea de față cu toate detaliile, dar putem afirma cu toată convingerea că regula prescriptivă pe care am urmărit-o mai sus nu corespunde uzului real.

Diferența de vîrstă înfățișată în Fig. 7 sugerează că nazalizarea oclusivelor sonore constituie un caz de schimbare fonologică în desfășurare. Din moment ce această variabilă a făcut obiectul unui intens prescriptivism, se ridică întrebarea dacă schimbarea fonologică este indicatorul unui proces de re- sau de de-standardizare. Ar fi de asemenea interesant de știut dacă această schimbare este mediată, i.e. dacă a fost iniţiată de sau reflectată în media audio-video. Pentru a da un răspuns acestor întrebări, am desfășurat un mic studiu.

\begin{tabular}{lllll} 
Crainic & Perioadă, Mediu & discurs & $\mathbf{\%}$ & $\#$ \\
\hline \multirow{2}{*}{ Tremi, Olga } & aprilie 2015, Mega & pre-scris & 55 & $33 / 60$ \\
& liber & 23 & $21 / 91$ \\
\hline \multirow{2}{*}{ Stai, Elli } & ianuarie-iunie 2013, & pre-scris & 63.6 & $35 / 55$ \\
\cline { 2 - 5 } & NET & liber & 21.8 & $12 / 55$ \\
\hline \multirow{2}{*}{ Kosioni, Sia } & martie-iulie 2014, & pre-scris & 52.4 & $44 / 84$ \\
& SKAI (radio) & liber & 30.9 & $25 / 81$ \\
\hline \multirow{2}{*}{ Meleti, Eleonora } & noiembrie 2014, E & pre-scris & 14.7 & $18 / 122$ \\
\cline { 3 - 5 } & ("Hastag”) & liber & 6.7 & $8 / 120$ \\
\hline \multirow{2}{*}{ Choukli, Maria } & ianuarie-iunie 2015, & pre-scris & 53.7 & $44 / 82$ \\
& ANT1 & liber & 32.9 & $23 / 70$ \\
\hline Chatzinikolaou, & ianuarie-iunie 2015, & pre-scris & 52.2 & $35 / 67$ \\
\cline { 3 - 5 } Nikos & STAR/Real FM & liber & 22.4 & $15 / 67$ \\
\hline Panagiotopoulos, & iunie 2017, ERT & pre-scris & 50.8 & $31 / 60$ \\
Nikos & & liber & 15.7 & $13 / 70$
\end{tabular}

Tabela 4: Nazalizarea în discursul pre-scris și liber a șapte crainici de știri. Toate scorurile z pentru diferențierea discursurilor pre-scrise și libere sînt semnificative la $p<0.01$. Sursa: Datele au fost colectate de Stavroula Vergopoulou, Olympia Antonena și Melina-Dionysia Konti (Stai); Giorgos Koukoulis (Kosioni); Georgios-Konstantinos Oikonomopoulos (Meleti); Michalis Psimitis (Choukli); Kyrgia Ioanna și Ksiromamou Andrianna (Chatzinikolaou); Alexandros Potamianos (Panagiotopoulos). 
Ne-am oprit asupra discursurilor a șapte crainici de știri, cinci femei și doi bărbați, de televiziune și radio. Avem motive să credem că cei mai mulți, dacă nu toți acești crainici fuseseră consiliați lingvistic şi că erau familiarizaţi cu regula privind nazalizarea. Pentru a limita interferențele factorilor irelevanți, am luat în considerare numai ocurențele consoanelor oclusive sonore prenazalizate din interiorul cuvintelor, în poziție intervocalică $\left(V_{-}\right.$V). Am exclus, de asemenea, „cuvintele de origine străină”, cum ar fi numele străine (e.g., Bó $\lambda \phi \gamma \kappa \alpha \nu \gamma \kappa$ $\sum o ́ l \mu \pi \lambda \varepsilon<$ Wolfgang Schäuble, pronunțat [soible] sau [soimble] în greacă). Tabela 4 conţine numele crainicilor, perioada transmisiunilor şi canalul transmisiunilor (radio sau televiziune: cele mai multe transmisiuni sînt de televiziune, dar în două cazuri, cele ale jurnaliștilor O. Cosioni și N. Chatzinikolaou, a trebuit să completăm datele despre discursul liber pe baza transmisiunilor lor de radio). Factorul stilistic de care s-a ținut cont a fost cel ce ține de calitatea discursului: pre-scris vs. liber. Înțelegem prin discurs pre-scris discursul citit sau susţinut de prompter; discursul liber apare cînd crainicii intervievează un invitat în emisiune sau cînd poartă o conversaţie cu un alt jurnalist. Pentru a ne asigura că un asemenea discurs nu a fost totuşi pre-scris, segmentele inițiale ale conversațiilor au fost excluse din analiză.

Procentajele medii ale prenazalizării oclusivelor intervocalice în discursul pre-scris și liber apar în Tabela 4 și, sub formă de diagramă, în Fig. 8. Se observă limpede un tipar: toți crainicii de știri nazalizează semnificativ mai puțin în discursul liber. Situația este aceeași și în cazul excepțional al lui E. Meleti, o crainică de televiziune care a funcționat și ca gazdă a mai multor show-uri mondene; în general, Meleti nazalizează mai puțin decît ceilalți, probabil pentru că este mai tînără sau/și pentru că intenționează să se prezinte pe sine ca mai tînără.

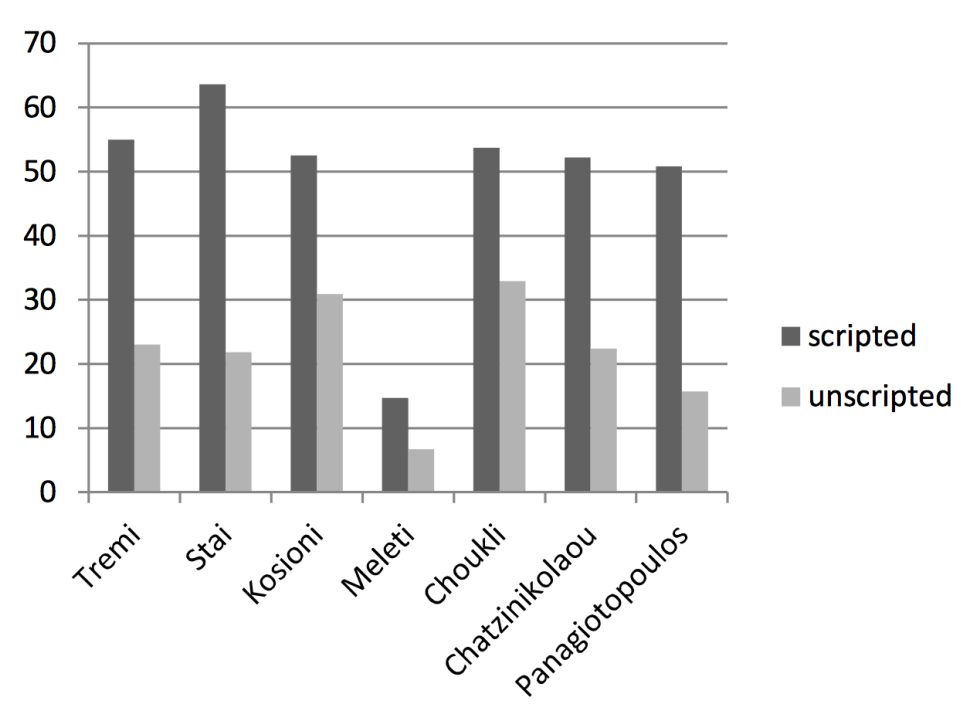

Figura 8: Procentaje ale nazalizării în discursul pre-scris și liber a șate crainici de știri.

Să rezumăm concluziile noastre pînă acum. Regula prescriptivă pentru prenazalizarea consoanelor oclusive sonore e greu de respectat; este destul de complexă și presupune cunoștințe metalingvistice care nu se află la îndemîna vorbitorului obișnuit de GMS. Regula prescriptivă ia în considerare doi factori de diferențiere: vecinătățile (contextul) lingvistice și originea cuvintului (greacă vs. străină). În contrast, cercetările de sociolingvistică au stabilit că factorii principali sînt: vîrsta și stilul (în chiar această ordine a importanței). Cu toate că stilul este factor secundar, prenazalizarea pare să se încarce stilistic în media, după cum o arată rezultatele semnificativ diferite obținute din analiza discursurilor pre-scrise vs. libere. Se pare că discursul este refractar la instrucțiunea prescriptivă cînd este liber. Uzul liber este acela care se prezintă cel mai adesea de-ideologizat.

A eșuat regula prescriptivă? Este ea o regulă de a cărei aplicare nu s-a mai îngrijit nimeni, una care ar putea fi revitalizată dacă vorbitorilor li s-ar atrage atenția asupra greșelilor pe care le comit, după cum 
pare a crede prescriptivismul? Sau poate că această absență a nazalizării reprezintă o nouă fază în evoluția fonologiei unei limbi standard, în ciuda normelor Standardului; o evoluție care poate fi recunoscută ca re- sau de-standardizare a Standardului tocmai pentru că ea sfidează norma prescriptivă asociată acestuia... Dacă, aşa cum am procedat de la începutul acestui lung studiu, adoptăm înțelegerea că o limbă standard ar trebui definită și ca limbă, și ca set de norme, atunci denazalizarea oclusivelor sonore poate fi văzută ca o nouă etapă în evoluția GMS, care, pentru că sfidează norma prescriptivă, relevă o nouă tendință de de-/re-standardizare.

\section{Concluzii și discuții}

Am prezentat în această lucrare o viziune asupra unei limbi standard ca Standard (normă, ideal, ideologie) și Limbă (i.e., uz real care se conformează, mai mult sau mai puțin, normei, idealului, ideologiei). Am văzut că o limbă standard este imposibil de definit fără să ne referim la normele ei. Am văzut de asemenea că există o interconexiune între norme și Limbă; că normele sînt influențate de uzul real și că uzul este constrîns să se conformeze normelor care prevalează într-o comunitate, într-o anume perioadă de timp. Chiar și atunci cînd normele sînt clar definite și cînd se dezvoltă uzuri noi (stilistice), aceste uzuri nu pot fi înțelese în afara legăturilor lor cu normele, vechi sau noi. Fromkin, Rodman \& Hyams (2011, p. 440) s-au aflat în eroare: putem identifica vorbitorii unei limbi standard după normele pe care le folosesc în discursul lor oral—desigur, nu cu absolută precizie; normele nu sînt niciodată precise.

Există aspecte ale normelor lingvistice (și ale ideologiei care le înconjoară) care nu pot fi înțelese literal. De exemplu, o limbă standard ar putea fi considerată „uniformă” sau „neutră”. Uniformitatea şi neutralitatea (de-ideologizarea) sînt constructe ideologice și nu trebuie înțelese ca atare. Milroy \& Milroy (1999, p. 22, 51, 58), printre alții, scot în evidență uniformitatea ca principalul scop al standardizării (cf. Milroy, 2001, p. 531: „standardizarea constă în impunerea uniformităţii asupra unei clase de obiecte”). Ne-am fi așteptat ca uniformitatea să fie proclamată mai degrabă ca noțiune pre-teoretică, iar nu să fie implicată la nivel teoretic. Evident, uniformitatea este parte componentă a „,ideologiei limbii standard”. Este un fenomen perceptual; ar putea foarte bine să fie o halucinație colectivă, nicidecum un rezultat real al practicilor de standardizare. Dar acesta este riscul abordării limbilor standard prin prisma normelor lingvistice: categoriile ideologice, i.e. concepții și credințe manipulate în metalimbajul care ghidează practicile de standardizare, sînt adesea înțelese literal și devin parte componentă a teoriei sociolingvistice. Aceleași observații se aplică și conceptului de „neutralitate”.

Deși conceptele de limbă standard și de norme ale limbii nu pot fi ținute departe unul de altul, este nevoie de un procedeu prin care să putem înțelege modul în care normele limbii afectează o limbă standard și viceversa. Am identificat calea de la metalimbă (normele limbii) la limbă (limbi standard) prin ceea ce am numit o teorie performativă a standardizării lingvistice. Am afirmat existența unui nou tip de act de vorbire, cu direcția de acomodare metalimbă - limbă, care nu a mai fost pînă acum discutat în literatura de specialitate dedicată actelor de vorbire: corectiva.

Ceea ce se înțelege prin 'corective' sau 'practici corective' este un comportament lingvistic şlefuit și motivat de evaluări ale uzului, ca „corect-incorect”, „bun-rău”, „propriu-impropriu”, „potrivit-nepotrivit”, „frumos-urît”, „elegant-vulgar” etc. Unele dintre aceste antonime au grade de comparaţie; altele, nu. Toate exprimă evaluări metalingvistice: „corect sau incorect” înseamnă „corect sau incorect spus sau construit”. Desigur, cele mai multe dintre corective se aplică limbii scrise; ceea ce înseamnă că „corect sau incorect” înseamnă mai ales „corect sau incorect scris”. Totuși, vorbirea, limba manifestată oral, poate fi și ea supusă evaluării și corectării, cum se întîmplă în procesul de învățare a limbii, în cel al antrenării vorbirii, sau în cel al instruirii cuiva pentru a deveni un comunicator eficient—proces analizat critic de Cameron (2000).

Practicile corective se fac cunoscute mai ales—dacă nu exclusiv—prin instrucțiuni corective, care îmbină proscrierea cu prescrierea: nu se spune sau scrie X, se spune sau scrie Y; ori: se spune și X, și Y, dacă C. Presupunem că există cel puțin un membru al unei comunități lingvistice care respectă aceste instrucțiuni, i.e. acel membru care le-a emis. Dar, de fapt, fiecare instrucțiune corectivă este parte a unui 
repertoriu asumat de mulți alți membri ai unei comunități lingvistice sau, gîndind la scară mai mică, ai unei comunități de literati. Practicile corective sînt practici sociale; sînt colective și orientate. Se poate presupune că grupurile de indivizi care respectă corectivele dau dovadă de o anumită organizare socială. Directivele sînt direcționate. Cu toate că instrucțiunile corective sînt emise de cei puțini, ele sînt adresate celor mulți; teoretic, ele sînt adresate oricui este educat. A respecta o instrucțiune înseamnă a-ţi alinia practica lingvistică la ea.

Practicile corective nu sînt apanajul doar al corectorilor, editorilor și al altor categorii profesionale din domeniul scrisului (Cameron, 1995, p. 34). Firește că practicile acestor bresle sînt cu deosebire interesante pentru un observator, pentru că sînt mai organizate (sau „uniforme”, dacă preferați), în comparație cu practicile corective ale altora. Totuși, practica corectivă reprezintă un fenomen mult mai răspîndit, depăşind în amploare alte tipuri de activităţi lingvistice. Să ne gîndim un moment la practicile corective asociate creșterii unui copil („cuvinte urîte”); sau cuvinte tabu; sau practica corectivă a eufemismului; a corectitudinii politice; a evitării expresiilor sexiste sau rasiste; să ne gîndim la cenzură sau la autocenzură ca practică corectivă; și, în sfîrșit, la practicile asociate cu standardizarea.

La fel, practicile corective nu vizează numai cuvintele sau numai unele expresii particulare-deși cuvintele sînt, e adevărat, ținta lor cea mai ușoară. Corectivele pot fi, de asemenea, îndreptate spre acte de vorbire (cum sînt înjurăturile, blestemele, jurămintele) sau spre evenimente de vorbire (cum sînt interviurile sau talk show-urile—care sînt supuse de obicei unor specificări prealabile). Corectivele pot avea în vedere registre întregi (cum este cazul îndreptarelor/ghidurilor de scriere sau al ghidurilor adresate în mod special jurnaliștilor, etc.); sau anumite forme literare (e.g., ritmul iambic de cincisprezece silabe considerat de mulți greci ca fiind „ritmul național”). Un comportament corectiv poate fi critic față de o limbă oarecare în întregime (e.g., mulți greci consideră italiana ca fiind „o limbă muzicală” și germana, una „barbară”).

Indiferent cît de generală ar fi definiția lor, practicile corective au două componente: ele sînt în același timp lingvistice și metalingvistice. Practicile corective sînt executate în limbă pe baza unui standard metalingvistic sau a unei norme, sau a unui ideal de limbă, sau a unei ideologii lingvistice. De obicei, norma metalingvistică poate fi exprimată sub forma unei instrucțiuni sau a unei directive formate dintro secvență prohibitivă, una normativă și una explicativă (i.e. o parte ce implică o formă negativă a lui ,ar trebui”, ,trebuie” și alte expresii deontice similare; o parte ce implică o expresie deontică pozitivă; și o parte ce implică „pentru că”, „deoarece...” și expresii explicative similare). Partea explicativă cuprinde adesea o evaluare precum „corect - incorect”: „nu trebuie să se spună sau scrie X; trebuie să se spună sau scrie Y, pentru că, e.g., X este incorect și Y este mai potrivit”. Și cele mai simple permisive sînt alcătuite, după cum am văzut, tot din trei părți: una permisivă ('se poate spune sau scrie și $X$, pe lîngă $Y$ '); una normativă, care de obicei precizează o condiție a utilizării X/Y ('X apare dacă C1; Y apare dacă C2'); și o parte explicativă, opțională ('pentru că Z').

Dacă instrucțiunile corective sînt respectate, rezultă o practică a respectivei corective; adică, rezultatul corectivei nu este să se scrie sau să se spună Y, ci să se scrie sau să se spună Y în loc de... sau pentru a face diferența între uzurile $\mathrm{X}$ și $\mathrm{Y}$ în funcție de o condiție C. Observăm că o corectivă are mai multe șanse să apară atunci cînd și X, și Y sînt atestate, e.g. cînd există o evidentă variaţie lingvistică. De asemenea, o directivă presupune că vorbitorul este conștient de existența lui X și Y; într-un fel, instrucțiunea corectivă aduce $\mathrm{X}$ și $\mathrm{Y}$ în atenția celor capabil să o respecte. Corectivele stimulează conștientizarea limbii de către utilizatorul ei.

Practicile corective sînt parte a procedeelor de re-/de-standardizare. Din moment ce practica corectivă combină o activitate (colectivă) cu standardul metalingvistic (o normă, o atitudine sau o evaluare), standardizarea reprezintă un teren foarte potrivit pentru studierea efectelor pe care le produc instrucțiunile corective. O limbă standard este, întocmai ca practica corectivă, două lucruri în același timp: i.e. este și limbă (un dialect între alte dialecte), şi standard (i.e., o normă prin mijlocirea căreia sînt „măsurate” și evaluate celelalte dialecte). În standardizare își unesc forțele mai multe instanțe (administrativă, educațională etc.), toate fiind necesare pentru ca corectivele să fie eficiente și pentru ca practicile corective să se răspîndească. Standardizarea este un multiplicator de corective. 
Studiul sistematic al instrucțiunilor corective ne-a permis să diagnosticăm normele prin care se produce standardizarea; putem observa schimbări la nivelul normelor și putem formula ipoteze despre posibile schimbări lingvistice cărora le răspund schimbările în normă. Analiza părților explicative ale instrucțiunilor de acest fel—și analiza discursului metalingvistic, în general—ne poate ajuta să înțelegem dacă și cum este percepută şi ideologizată schimbarea lingvistică, într-o comunitate lingvistică.

Am adoptat o perspectivă descriptivă asupra prescriptivismului. Întocmai precum variabilele lingvistice reprezintă instrumentele perspectivei descriptive asupra variației, corectivele pot fi studiate ca variabile sociolingvistice (cu variantele X și Y). Se pot cuantifica astfel efectele prescriptivismului. Într-adevăr, corectivele sînt unitățile elementare în studiul cantitativ al prescriptivismului în interiorul unei paradigme variaționiste. Corectivele sînt mediatori între metalimbă și limbă. Tot astfel, studiul instrucțiunilor corective (din îndreptare și ghiduri de uz, gramatici tradiționale, manuale etc.) este esențial pentru a se putea diagnostica a) repertoriile de corective care concurează ori domină într-o comunitate lingvistică; b) evaluarea unor asemenea repertorii și a unor evoluții concomitente în normă; c) direcțiile de comunicare prin care normele se propagă și sînt difuzate într-o comunitate. Studiul corectivelor ajută la formularea unor ipoteze pertinente despre d) dacă standardizarea, atitudinile lingvistice sau ideologiile influențează schimbarea lingvistică și, dacă da, în ce mod, i.e. dacă există un lanț cauzal care leagă corectivele de schimbările de tipul $\mathrm{X} \rightarrow \mathrm{Y}$.

Studiul corectivelor ca unități elementare în cuantificarea prescriptivismului presupune existența unei teorii performative a normelor limbii şi a ideologiilor lingvistice în general (Moschonas, 2008; 2014, p. 422-424). Ideologiile lingvistice ar trebui înțelese ca „acte” lingvistice performative la nivel metalingvistic. „Direcția de acomodare” a acestor acte de limbaj este de la (meta)limbă la limbă sau, altfel spus, efectul lor perlocuționar este în ultimă instanță locuționar, i.e. efectul constă într-o schimbare la nivelul comportamentului lingvistic. Deoarece instrucțiunile corective sînt prescriptive, forța lor ilocuționară este aceea a unei directive. De aici, condițiile de reușită ale practicilor corective sînt și condiții ale schimbării lingvistice: așa cum rezultanta unui act lingvistic poate fi „fericită” sau „tristă” în anumite circumstanțe, efectuarea unei schimbări lingvistice poate fi productivă sau neproductivă în anumite perioade de timp, într-un context socio-cultural care trebuie specificat.

Cineva ar putea ridica obiecția că am pus prea mult accent nemeritat pe metalimbă, că standardizarea este posibilă și prin exemplu, că se poate institui o normă prin etalarea utilizării sale sau prin crearea unui context al utilizării ei. Notăm că acesta ar putea foarte bine să fie cazul cu standardul impus de Jannis Psycharis. În ciuda unor încercări mai tîrzii de „codificare” a normei sale într-o manieră strictă, Psycharis a standardizat greaca modernă prin faptul că și-a fixat un standard literar pe care l-au urmărit și alții în încercările lor de a scrie în demotică; a standardizat greaca modernă prin faptul că a arătat că greaca modernă poate fi standardizată. Dacă așa stau lucrurile, standardizarea reprezintă un proces prin care se creează uzuri exemplare. Haugen (1966a,b) ar aplica acestui proces termenul de „elaborare”.

Din perspectiva teoriei actelor de vorbire extinsă pe care am prezentat-o în lucrarea de faţă, pentru a putea într-adevăr fi luat în considerare ca uz exemplar, ar trebui să se conceadă că un asemenea uz presupune un act metalingvistic indirect, unul blazon/eliptic (de tipul: $\varnothing / Y$ ). Utilizarea în scris a acestei variante sau a alteia $(\mathrm{Y})$ implică ideea că această variantă sau cealaltă ar trebui utilizată în toate scrierile, iar această din urmă implicație nu este altceva decît un act metalingvistic ascuns. Cum „se ajunge” la acest act nu este o chestiune trivială; totuşi, asocierea unui uz exemplar cu actul metalingvistic care prescrie acest uz poate fi obținută numai în interiorul unui discurs metalingvistic mai larg. „Chestiunea limbii grecești” a reprezentat cadrul discursiv-ideologic mai larg care a permis asemenea asocieri între precepte şi uz. Este adevărat că o teorie performativă a standardizării trebuie să ţină cont de două tipuri de norme: cele impuse prin instrucțiuni explicite și cele fixate implicit prin utilizatorii (educați) ai limbii. În anumite condiţii, cele din categoria a doua se pot dovedi la fel de eficiente ca primele. S-ar putea și ca normele fixate prin puterea exemplului să fie favorizate în primul rînd de calitățile lor „estetice” și/sau de prestigiu.

O teorie performativă a ideologiilor lingvistice și a standardizării ar trebui să îndeplinească alte cîteva cerințe. Mai întîi, o tipologie a performativelor lingvistic ideologice ar trebui să încerce să cuprindă mai de- 
grabă practici lingvistice decît acte individuale. Ideologiile lingvistice reușesc să-și exercite farmecul numai prin practici colective precum standardizarea, purismul lingvistic, învățarea și predarea limbii etc. Desigur, unor asemenea practici prescriptive ar trebui să li se alăture „intenţii colective” ireductibile (Searle, 2002, p. 90-105). În al doilea rînd, intenţiile colective se manifestă colectiv. Prin urmare, tipurile performative la nivel metalingvistic ar trebui asociate cu secvențe comunicative mediate de presă (scrisă, audio-vizuală, electronică etc.); de asemenea, ar trebui asociate cu anumite specii, precum sînt articolele de cultivare a limbii, în presă, ori manualele editare (Cameron, 1995). Cu alte cuvinte, categoriile de performative nu ar trebui extrase tale quale din literatura care asociază actele de vorbire cu exemple specifice de afirmații.

Pentru studiul caracterului performativ al ideologiilor lingvistice, practicile corective sînt exemplare sub mai multe aspecte: Corectivele sînt valorizate social (ele sînt corelate cu norme lingvistice, precum și cu valori, credințe și atitudini ale comunității). Pot fi diagnosticate la nivel lingvistic, deși sînt exprimate, catalogate și dezbătute la nivel metalingvistic. Prezintă „sinceritate” și „,condiții de satisfacție” clare, adică cele recunoscute în instrucțiunile corective. Practicile corective respectă o anumită organizare socială. Mai ales cînd slujesc standardizarea, corectivele urmează calea medierii: dinspre o elită spre un mic grup de simpatizanți, susținători sau propagatori și, de acolo, spre publicul larg. De obicei grupul din mijloc, de susținători și propagatori, este cel care folosește mijloacele de comunicare în masă pentru a-și exprima concepțiile despre norme și limbă.

Mi-am expus viziunea asupra limbii standard printr-o serie de studii asupra evoluției GMS. M-au preocupat în mod special cele patru etape din evoluția GMS: planificarea (1), etapa dezvoltării normei și a difuzării normelor (2), etapa naturalizării (sau a „neutralizării”) normelor (3) și etapa de-/re-standardizării prin dezvoltarea unor uzuri care contravin normelor acceptate. Cele trei schimbări din urmă sînt toate mediate, i.e. au fost toate iniţiate în și/sau propagate prin medii electronice sau tipărite-în modalităţi pe care le-am explicat în secțiunile 2-4. S-ar putea spune că schimbarea determinată de ideologie, dacă apare, este întotdeauna mediată.

Din cauza persistenței „Chestiunii limbii”, diglosia a dat naștere în Grecia la două standarde antagonice, cel purist sau arhaic și cel demotic sau vernacular. Sigur că la ele s-ar putea adăuga cîteva standarde intermediare, aflate între cele două extreme. Se spune că GMS se întemeiază pe varianta demotică, îngăduind totuşi existența unui număr de arhaisme, mai ales în registrele înalte ale limbii. Cum formele vernaculare au devenit treptat norme, este rîndul formelor arhaice acum să necesite instrucțiuni corective şi îndrumare. Am văzut că s-a cristalizat un nou model morfo-sintactic/frazeologic care să corespundă acestor norme „mixte” ale GMS.

În prezentarea transformărilor GMS, am adus în discuție aspecte ale cercetărilor mele care nu sînt accesibile publicului de limba engleză interesat de problema standardizării. Se ascunde aici o problemă reală a studiilor asupra standardizării, deoarece, vizînd diverse limbi, ele fac parte din literaturile naționale şi nu sînt la îndemna cititorului străin; numai o mică parte din aceste studii sînt comparative. Studiile despre standardizare trebuie să depășească bariera lingvistică impusă pînă acum de literaturile naționale pe această temă.

Există la ora actuală o masă semnificativă de cercetări asupra standardizării, medierii și schimbării lingvistice. Studiile din Kristiansen \& Grondelaers (2013) au în vedere normele din media în Europa contemporană, în încercarea de a pune în evidență procesul de 'demotizare' [engl.: demotisation] (o configurație standard-multiplă în care mai mult de o varietate lingvistică satisface criteriul de 'cea mai bună limbă) și 'destandardizare' (o configurație în care idealul în sine de limbă standard nu mai există; v. mai ales Coupland \& Kristiansen, 2011). Studiile empirice, experimentale din Kristiansen \& Grondelaers (2013) îşi propun să sesizeze schimbări importante în jocul dintre normele lingvistice și limbile standard, în mai multe țări europene. Cele două volume Thøgersen, Coupland \& Mortensen (2016) și Mortensen, Coupland \& Thøgersen (2017) încearcă să explice asemenea realinieri utilizînd conceptul de 'stilizare' [engl.: 'styling'].

De asemenea, s-au scris studii importante ce caută să evidențieze efectele prescriptivismului asupra schimbării lingvistice: Anderwald (2014, 2016), Hinrichs, Szmrecsanyi \& Bohmann (2015), Curzan 
(2014), Tieken-Boon van Ostade (2006); v. și lucrările lui Stuart-Smith enumerate în bibliografie, care încearcă să vadă dacă medierea reprezintă un factor activ în schimbarea lingvistică. Anderwald (2016), Hinrichs, Szmrecsanyi \& Bohmann (2015), Poplack \& Dion (2009), Poplack, Lealess \& Dion (2013) sînt citteva dintre cele mai importante lucrări recente preocupate să demonstreze efectele prescriptivismului, prin corelarea a două tipuri de corpora lingvistice: texte prescriptive care conțin instrucțiuni corective (aşa cum apar el în ghiduri și îndreptare lingvistice și în gramatici tradiționale ale limbii engleze) și corpora istorice de limbă.

Cred că teoria performativă a standardizării pe care am dezvoltat-o în această lucrare oferă un cadru unificator pentru diverse abordări ale prescriptivismului. ar putea, de asemenea, să contribuie la reexaminarea și problematizarea unor destul de comune credințe greșite despre standardizare, cum ar fi cea în uniformitatea şi neutralitatea unui Standard sau cea că normele lingvistice, întocmai ca ideile platonice, nu se schimbă sau, dacă se schimbă, se schimbă foarte încet. Acesta ar putea fi cazul englezei standard: s-a afirmat într-adevăr că „engleza corectă” [engl.: proper English] se definește încă după aceleași standarde formulate în secolul XVI (Machan, 2009; cf. Schaffer, 2010). Greaca modernă, pe de altă parte, la fel ca multe alte limbi „reformate”, a cunoscut schimbări abrupte de normă. Literatura dedicată standardizării nu poate decît să profite de pe urma comparării cercetărilor empirice efectuate asupra a diferite limbi și a diferite procese de standardizare.

\section{Precizări și mulțumiri}

Ideea unei teorii performative a ideologiilor lingvistice și standardizării a fost mai întîi prezentată sub titlul On the performative character of language ideologies la a IX-a Conferință Internațională de Pragmatică, Riva del Garda - 14 iulie 2005. În forma ei actuală, lucrarea a fost prezentată pentru prima dată sub titlul Changes in language standards as changes in standard languages: The case of media norms, la al XIX-lea Simpozion de Sociolingvistică, Freie Universität Berlin - 21 august 2012, la secțiunea „Changing linguistic norms in the audiovisual media”, organizată de Jakob Thoegersen și Tore Kristiansen. O lucrare despre standardul non-uniform al lui Triantaphyllidis a fost prezentată la a IV-a Conferință despre Prescriptivism, Universiteit Leiden - 13 iunie 2013, sub titlul Non-uniform standards: The case of Standard Modern Greek,

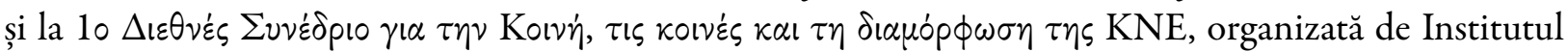

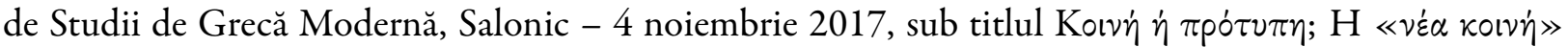

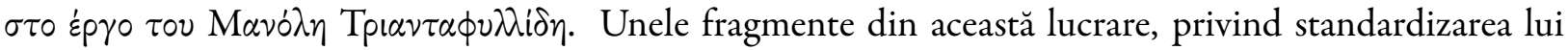
Triantaphyllidis și „de-ideologizarea” Standardului vor apărea sub titlul Prescriptive acts: A performative theory of language standardization în Antos, G., Niehr, T. \& Spitzmüller, J. (eds), Handbuch Sprache im Urteil der Öffentlichkeit, de Gruyter, Berlin, 2019.

Sînt profund îndatorat editorilor revistei „Diacronia” pentru prilejul de a-mi prezenta o parte din preocupările mele privind standardizarea și pentru comentariile și observațiile lor critice, care m-au ajutat să îmi desăvîrșesc argumentația.

Doresc să-mi exprim gratitudinea față de toți studenții cursului meu de „Media Sociolinguistcs” și "Media Discourse Analysis” de la Dpt. of Communication and Media of the University of Athens, care au dus la bun sfîrșit sarcini de cercetare asupra unor probleme discutate și în lucrarea de față sau care au exprimat idei interesante legate de acestea. Numele lor sînt menționate în Cuprins și în secțiunea rezervată surselor pentru Fig. 5, 6 și Tabela 4, dar este pe deplin nimerit să mulțumesc încă o dată aici lui: Alexandros Potamianos, Andrianna Ksiromamou, Apostolia Balomenou, Artemis Sofiou, Dimitra Koutsou, Ioanna Kyrgia, Melina-Dionysia Konti, Giorgos Koukoulis, Georgios-Konstantinos Oikonomopoulos, Michaela Kolia, Michalis Psimitis, Olympia Antonena, Anna Vassilaki, Stavroula Vergopoulou, Tina Fourlari. 


\section{Bibliografie}

Agha, A. (2007). Language and Social Relations, Cambridge University Press, Cambridge, Crossref.

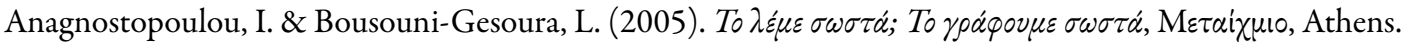

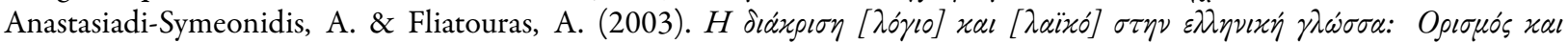
$\tau \alpha \xi \iota v o ́ \mu \eta \sigma \eta$, în $\sigma^{\text {th }}$ International Conference of Greek Linguistics, University of Crete - Laboratory of Linguistics, Rethymno, p. 1-16.

Anderwald, L. (2014). Measuring the success of prescriptivism: Quantitative grammaticography, corpus linguistics and the progressive passive, în „English Language and Linguistics”, 18 (1), p. 1-21, Crossref.

Anderwald, L. (2016). Language Between Description and Prescription: Verbs and Verb Categories in Nineteenth-Century Grammars of English, Oxford University Press, Oxford, Crossref.

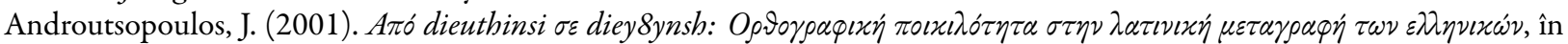
Agouraki, Y. et al. (eds), Proceedings of the $4^{\text {th }}$ International Conference in Greek Linguistics, p. 383-390, University Studio Press, Thessaloniki.

Androutsopoulos, J. (2009). 'Greeklish': Transliteration practice and discourse in the context of computer-mediated digraphia, în Georgakopoulou, Al. \& Silk, M. (eds), Standard Languages and Language Standards: Greek, Past and Present, p. 221-249, King's College - Center for Hellenic Studies / Ashgate, London.

Arvaniti, A. \& Joseph, B. (2000). Variation in Voiced Stop Prenasalization in Greek, în „Г $\lambda \omega \sigma \sigma 0 \lambda \circ \gamma$ ia/Glossologia”, 11-12, p. $131-166$.

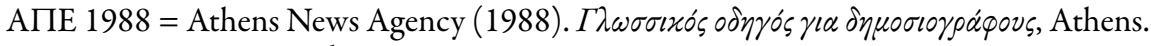

Austin, J.L. (1975 [1962 $\left.\left.{ }^{1}\right]\right)$. How to Do Things With Words, Oxford University Press, Oxford, Crossref.

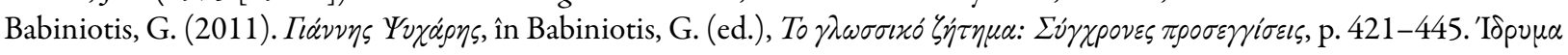

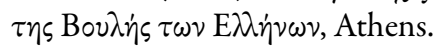

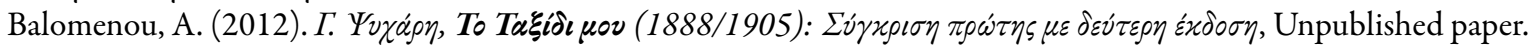

Blommaert, J. (ed.) (1999). Language Ideological Debates, Mouton de Gruyter, Berlin/New York, Crossref.

Bourdieu, P. (1991). Language and Symbolic Power, translated by G. Raymond \& M. Adamson, Polity, Cambridge.

Cameron, D. (1995). Verbal Hygiene, Routledge, London/New York.

Cameron, D. (2000). Good to Talk? Living and Working in a Communication Culture, Sage, London.

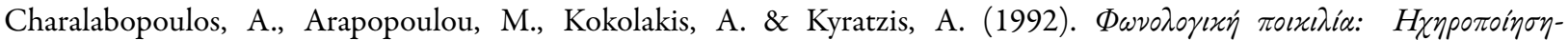

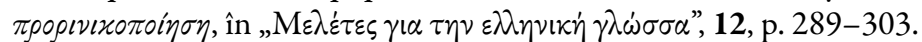

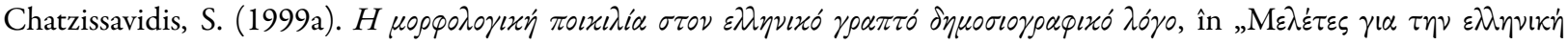

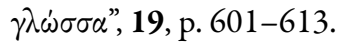

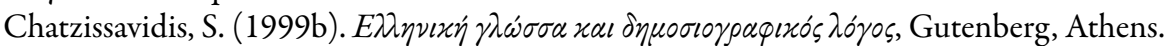

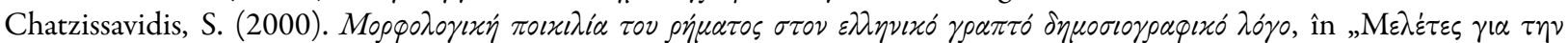
$\varepsilon \lambda \lambda \eta \nu เ \kappa \eta \dot{~} \gamma \lambda \omega \sigma \sigma \sigma \alpha, 20$, p. 588-599.

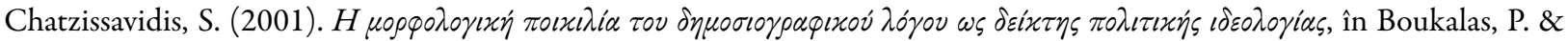

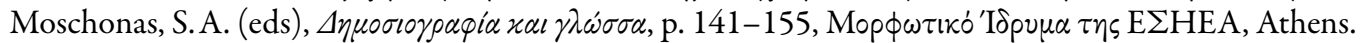

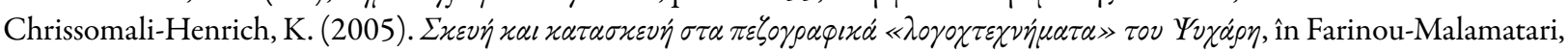

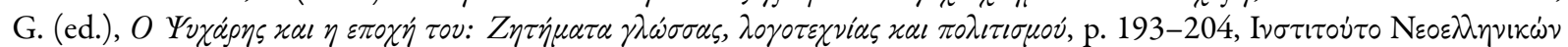
$\Sigma \pi \circ v \delta \omega \nu$, Thessaloniki.

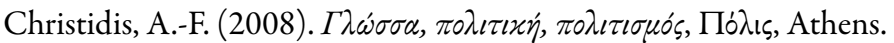

Coupland, N. \& Kristiansen, T. (2011). SLICE: Critical perspectives on language (de)standardization, în Kristiansen, T. \& Coupland, N. (eds), Standard Languages and Language Standards in a Changing Europe, p. 10-35, Novus, Oslo.

Crowley, T. (1989). Standard English and the Politics of Language, University of Illinois Press, Urbana/Chicago.

Curzan, A. (2014). Fixing English: Prescriptivism and Language History, Cambridge University Press, Cambridge, Crossref.

Delveroudi, R. \& Moschonas, S. A. (2003). Le purisme de la langue et la langue du purisme, în „Philologie im Netz”, 24, p. 1-26, [online, accessed 9/8/2019].

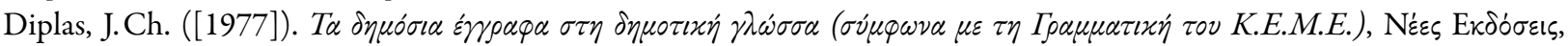
Athens.

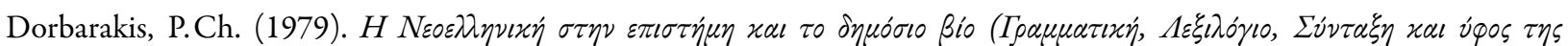
$\left.\Delta \eta \mu о \tau i x \operatorname{s}^{\prime}\right), \mathrm{E} \sigma \tau i \alpha$, Athens.

Ewert, A. (1940). Dante's Theory of Language, în „The Modern Language Review”, 35 (3), p. 355-366, Crossref.

Fishman, J. A. (1972). The Sociology of Language: An Interdisciplinary Social Science Approach to Language in Society, Newbury House, Rowley, Mass.

Fodor, I. \& Hagège, Cl. (eds) (1983-1990). Language Reform: History and Future, 5 vols, Buske Verlag, Hamburg.

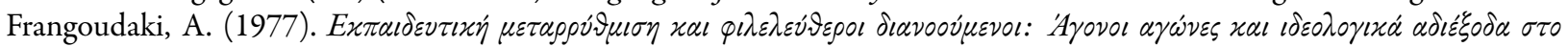

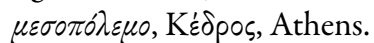

Frangoudaki, A. (1992). Diglossia and the Present Language Situation in Greece: A Sociological Approach to the Interpretation of Diglossia and Some Hypotheses on Today's Linguistic Reality, în „Language in Society”, 21 (3), p. 365-381, Crossref. 
Fromkin, V., Rodman, R. \& Hyams, N. (2011). An Introduction to Language, $9^{\text {th }}$ ed., Wadsworth, Boston.

Geeraerts, D. (2016). Cultural models of linguistic standardization, în „Diacronia”, 3, 12 feb., art. A36, Crossref.

Goffman, E. (1981). Radio talk: A study of the ways of our errors, în Forms of Talk, p. 197-330, University of Pennsylvania Press, Philadephia.

Grondelaers, S. \& Kristiansen, T. (2013). On the need to access deep evaluations when searching for the motor of standard language change, în Kristiansen, T. \& Grondelaers, S. (eds), Language (De)standardisation in Late Modern Europe: Experimental Studies, p. 9-52, Novus, Oslo.

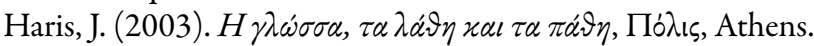

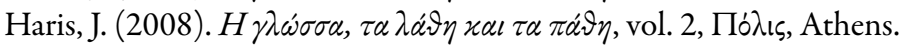

Haugen, E. (1966a). Language Conflict and Language Planning: The Case of Modern Norwegian, Harvard University Press, Cambridge, MA, Crossref.

Haugen, E. (1966b). Dialect, language, nation, în „American Anthropologist”, 68 (4), p. 922-935, Crossref.

Haugen, E. (2001). Standardization, în Mesthrie, R. (ed.), Concise Encyclopedia of Sociolinguistics, p. 681-683, Elsevier, Amsterdam.

Hickey, R. (ed.) (2010). Eighteenth-century English: Ideology and Change, Cambridge University Press, Cambridge, Crossref.

Hinrichs, L., Szmrecsanyi, B. \& Bohmann, A. (2015). Which-hunting and the Standard English relative clause, în "Language”, 91 (4), p. 806-836, Crossref.

Holmes, J. (2008 $\left.{ }^{3}\left[1992^{1}\right]\right)$. An Introduction to Sociolinguistics, Pearson, Harlow.

Horrocks, J. (20102 [1997']). Greek: A History of the Language and its Speakers, Wiley-Blackwell, Chichester, UK, Crossref.

Holton, D., Mackridge, P. \& Phillipaki-Warburton, I. (1997). Greek: A Comprehensive Grammar of the Modern Language, Routledge, London.

Hudson, R.A. (1980). Sociolinguistics, Cambridge University Press, Cambridge.

Inoue, M. (2006). Standardization, în Brown, K. (ed.), Encyclopedia of Languages and Linguistics, $2^{\text {nd }}$ ed, vol. 12, p. 121-127, Elsevier, Amsterdam, Crossref.

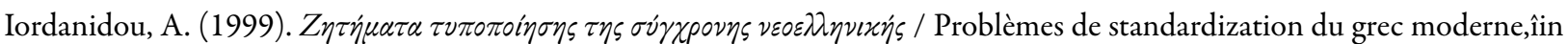

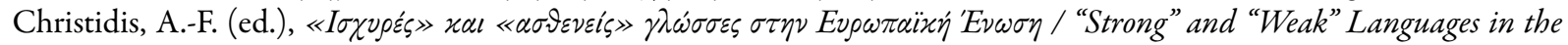

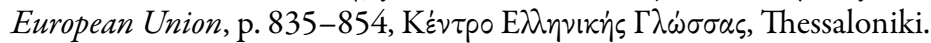

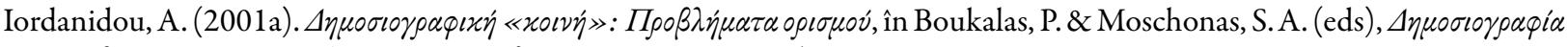

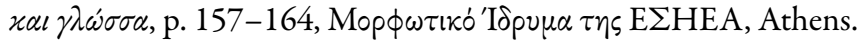

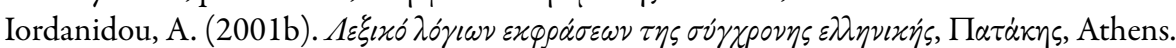

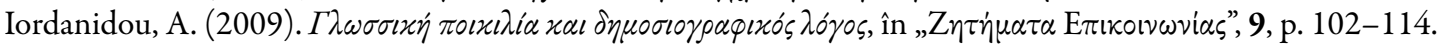

Jaffe, A. (2000). Introduction: Non-standard orthography and non-standardspeech, în „Journal of Sociolinguistics”, 4 (4), p. 497513, Crossref.

Jaffe, A., Androutsopoulos, J., Sebba, M. \& Johnson, S. (2012). Orthography as Social Action: Scripts, Spelling, Identity and Power, de Gruyter, Berlin, Crossref.

Jespersen, O. (1964² $\left.\left[1946^{1}\right]\right)$. Mankind, Nation and Individual from a Linguistic Point of View, Indiana University Press, Bloomington.

Johnson, S. (2005). Spelling Trouble? Language, Ideology and the Reform of German Orthography, Multilingual Matters, Clevedon, UK, Crossref.

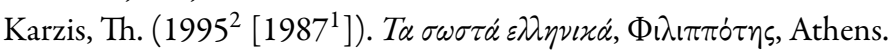

Kerswill, P. (2002). Koineization and accommodation, în Chambers, J. K., Trudgill, P. \& Schilling-Estes, N. (eds), The Handbook of Language Variation and Change, p. 668-702, Blackwell, Oxford, Crossref.

Kerswill, P. (2003). Models of linguistic change and diffusion: New evidence from dialect levelling in British English, în Britain, D. \& Cheshire, J. (eds), Social Dialectology: In honour of Peter Trudgill, p. 223-243, Benjamins, Amsterdam, Crossref.

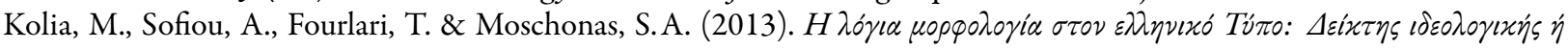

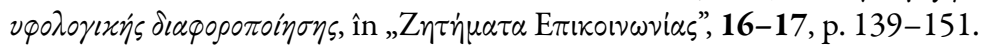

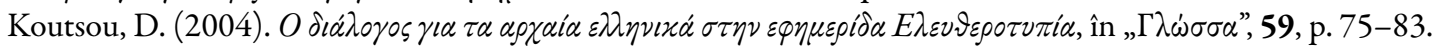

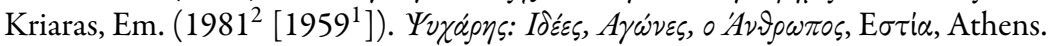

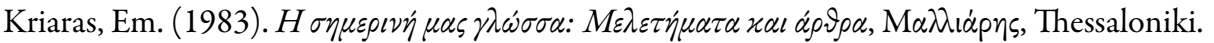

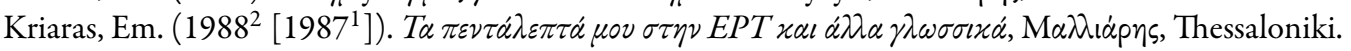

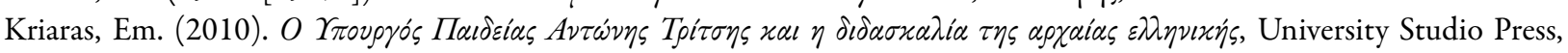
Thessaloniki.

Kristiansen, T. \& Grondelaers, S. (eds.) (2013). Language (De)standardisation in Late Modern Europe: Experimental Studies, Novus, Oslo.

Kristiansen, T. (2014). Does mediated language influence immediate language?, în Androutsopoulos, J. (ed.), Mediatization and Sociolinguistic Change, p. 99-126, de Gruyter, Berlin/Boston.

Labov, W. (1972). Sociolinguistic Patterns, University of Pennsylvania Press, Philadelphia.

Linn, A. R. (2011). Standardization, în Hogan, P.C. (ed.), The Cambridge Encyclopedia of the Language Sciences, p. 800-801, Cambridge University Press, Cambridge. 
Lippi-Green, R. $\left(2012^{2}\left[1997^{1}\right]\right)$. English with an Accent: Language, Ideology and Discrimination in the United States, Routledge, London/New York, Crossref.

Longmore, P. K. (2007). “Good English without Idiom or Tone”: The Colonial Origins of American Speech, în "Journal of Interdisciplinary History”, 37 (4), p. 513-542, Crossref.

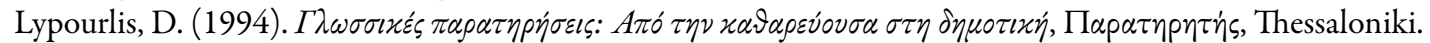

Machan, T.W. (2009). Language Anxiety: Conflict and Change in the History of English, Oxford University Press, Oxford.

Mackridge, P. (1985). The Modern Greek Language, Oxford University Press, Oxford.

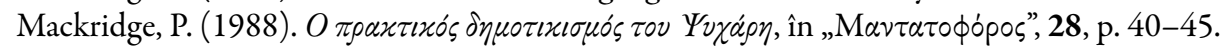

Mackridge, P. (2009). Language and National Identity in Greece, 1766-1976, Oxford University Press, Oxford, Crossref.

Mandilaras, B. G. (1972). Studies in the Greek Language, Athens.

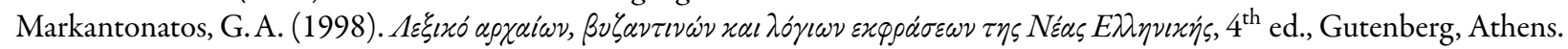

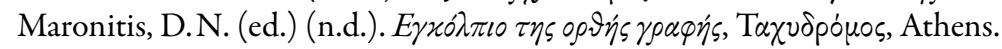

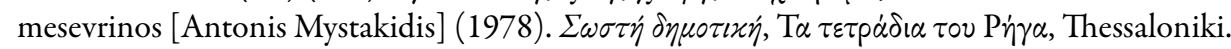

Mikros, G.K. (1997). Radio news and pnonetic variation in Modern Greek, în Drachman, G., Malicouti-Drachman, A., Fykias, I. \& Klidi, C. (eds), Greek Linguistics '95: Proceedings of the $2^{\text {nd }}$ International Conference on Greek Linguistics, vol. I, p. 35-44, The Department of Linguistics, University of Salzburg.

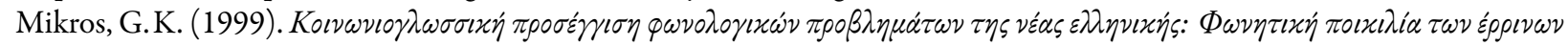
$\sigma \nu \mu \varphi \omega \nu \omega \nu$, Ph.D. thesis, Department of Linguistics, University of Athens.

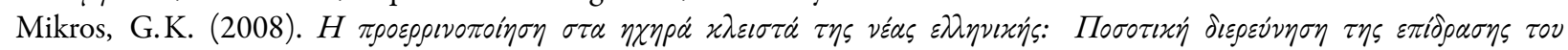

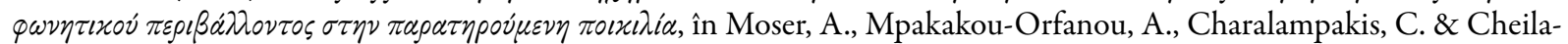

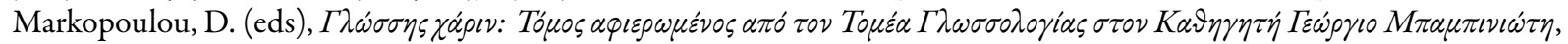

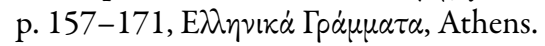

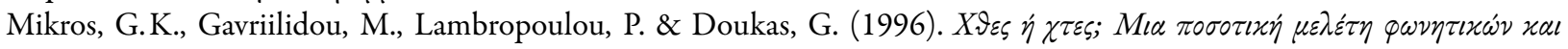

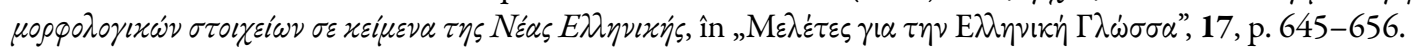

Milroy, J. (2001). Language ideologies and the consequences of standardization, în „Journal of Sociolinguistics”, 5 (4), p. 530-555, Crossref.

Milroy, J. \& Milroy, L. (19993 [1985']). Authority in Language: Investigating Standard English, Routledge, London/New York.

Mortensen, J., Coupland, N. \& Thøgersen, J. (2017). Style, Mediation, and Change: Sociolinguistic Perspectives on Talking Media, Oxford University Press, Oxford, Crossref.

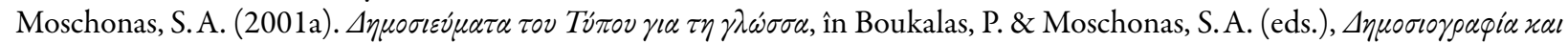

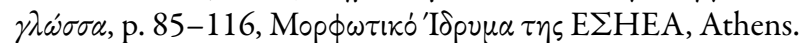

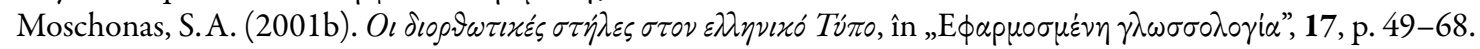

Moschonas, S. A. (2004). Relativism in Language Ideology: On Greece's Latest Language Issues, în „Journal of Modern Greek Studies", 22 (2), p. 173-206, Crossref.

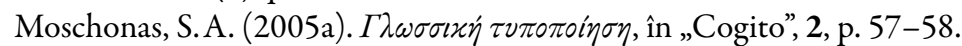

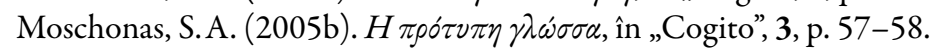

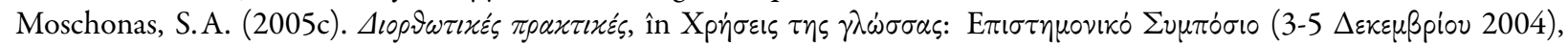

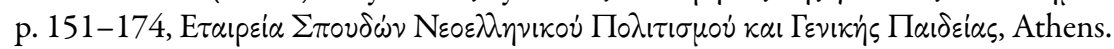

Moschonas, S. A. (2008). Vers une théorie performative du purisme, în „Le français moderne”, 76 (1), p. 38-50.

Moschonas, S. A. (2009). "Language issues" after the "Language Question”: On the modern standards of Standard Modern Greek, în Georgakopoulou, Al. \& Silk, M. (eds), Standard Languages and Language Standards: Greek, Past and Present, p. 293320, King's College - Center for Hellenic Studies / Ashgate, London.

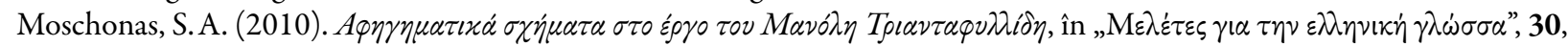
p. 398-410.

Moschonas, S. A. \& Spitzmüller, J. (2010). Prescriptivism in and about the media: A comparative analysis of corrective practices in Greece and Germany, în Johnson, S. \& Milani, T. (eds), Language Ideologies and Media Discourse: Texts, Practices, Politics, p. 17-40, Continuum Press, London.

Moschonas, S. A. (2014). The media on media-induced language change, în Androutsopoulos, J. (ed.), Mediatization and Sociolinguistic Change, p. 394-426, de Gruyter, Berlin/Boston.

Mugglestone, L. (2003 $\left.{ }^{2}\left[1995^{1}\right]\right)$. 'Talking Proper': The Rise of Accent as Social Symbol, Oxford University Press, Oxford.

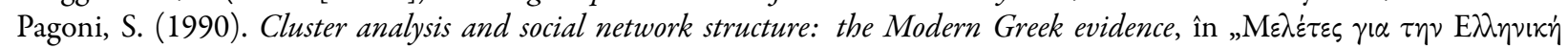
$\Gamma \lambda \omega \sigma \sigma \alpha$, 10, p. 399-419.

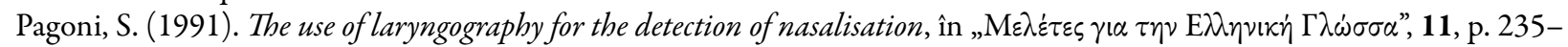
253.

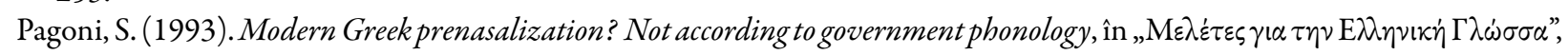
14, p. 355-369.

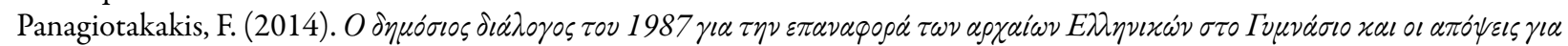
$\tau \eta \nu \varepsilon \lambda \lambda \eta \nu \iota x \eta \dot{~} \gamma \lambda \omega \sigma \sigma \alpha$, M.A. thesis, Department of Linguistics, University of Athens. 


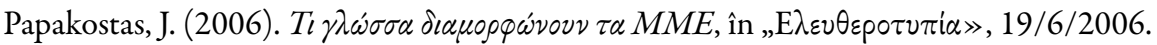

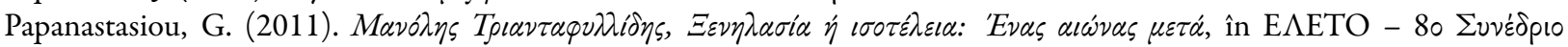

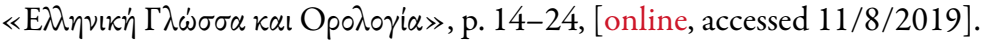

Papazafeiri, I. (1987). $\Lambda \alpha \dot{\imath} \eta \sigma \tau \eta \chi \rho \eta \dot{\sigma} \eta \tau \eta \varsigma \gamma \lambda \hat{\omega} \sigma \sigma \alpha \varsigma \mu \alpha \varsigma, \Sigma \mu i \lambda \eta$, Athens.

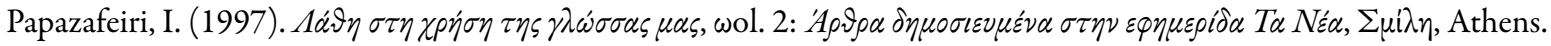

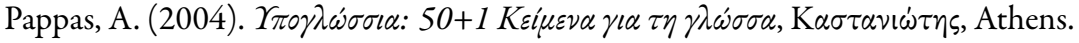

Pickl, S. (2019). Factors of selection, standard universals, and the standardisation of German relativisers, în "Language Policy”, Crossref.

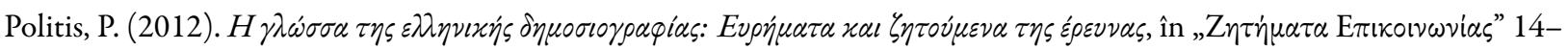
15, p. 59-72.

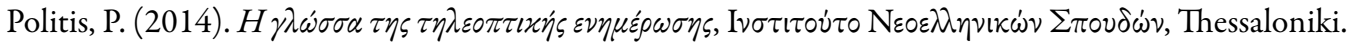

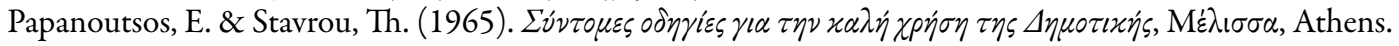

Poplack, S., van Herk, G. \& Harvie, D. (2002). 'Deformed in the dialects': An alternative history of non-standard English, în Watts, R. \& Trudgill, P. (eds), Alternative Histories of English, p. 87-110, Routledge, London.

Poplack, S. \& Dion, N. (2009). Prescription vs. praxis: The evolution of future temporal reference in French, în „Language”, 58 (3), p. 557-587, Crossref.

Poplack, S., Lealess, A. \& Dion, N. (2013). The evolving grammar of the French subjunctive, în „Probus”, 25 (1), p. 139-195, Crossref.

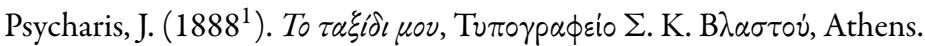

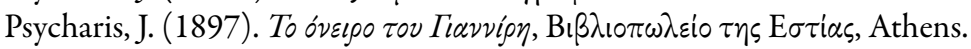

Psycharis, J. $\left(1905^{2}\right)$. To $\tau \alpha \xi i \delta \iota ~ \mu о \nu, ~ E \sigma \tau i \alpha$, Athens.

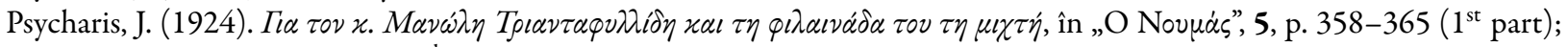
„O Nouráds”, 6, p. 405-412 (2 $2^{\text {nd }}$ part).

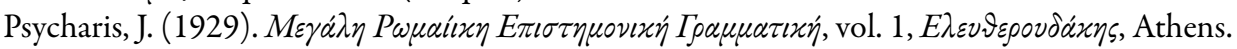

Psycharis, J. (1930). Quelques travaux de linguistique de philologie et de littérature helléniques: 1884-1928, vol. I. Les Belles Lettres, Paris.

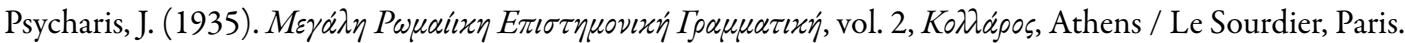

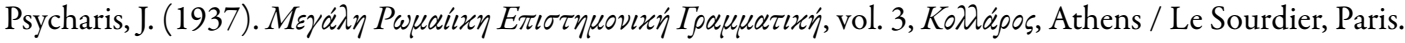

Rutten, G. (2016). Standardization and the myth of neutrality in language history, în „International Journal of the Sociology of Language", 242, p. 25-57, Crossref.

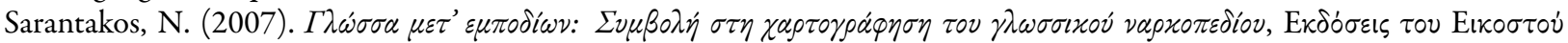
$\Pi \rho \dot{\omega} \tau \circ v$, Athens.

Schaffer, D. (2010). Old whine in new bottles: Mass-market prescriptivism from the 70s to the present, în Donaher, P. (ed.), Barbarians at the Gate: Studies in Language Attitudes, p. 44-87, Cambridge Scholars Publishing, Cambridge.

Searle, J. (1979). Expression and Meaning: Studies in the Theory of Speech Acts, Cambridge University Press, Cambridge, Crossref.

Searle, J. (2002). Consciousness and Language, Cambridge University Press, Cambridge, Crossref.

Sebba, M. (2007). Spelling and Society: The Culture and Politics of Orthography Around the World, Cambridge University Press, Cambridge, Crossref.

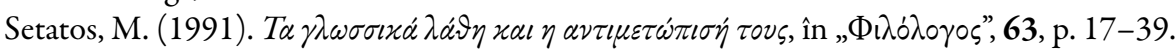

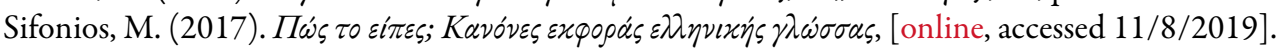

Silverstein, M. (2001 [1981']). The limits of awareness, în Duranti, A. (ed.), Linguistic Anthropology: A Reader, p. 382-401, Blackwell, Oxford.

Stuart-Smith, J. (2005). Is TV a contributory factor in accent change in adolescents?, ESRC End of Award Report, p. 1-23, R000239757, ESRC, Swindon, [online, accessed 1/8/2019].

Stuart-Smith, J. (2006). The influence of the media, în Llamas, C., Mullany, L. \& Stockwell, P. (eds), The Routledge Companion to Sociolinguistics, p. 140-148, Routledge, London.

Stuart-Smith, J., Timmins, C. \& Tweedie, F. (2007). 'Talkin' Jockney'? Variation and change in Glaswegian accent, în "Journal of Sociolinguistics", 11 (2), p. 221-260, Crossref.

Stuart-Smith, J., Pryce, G., Timmins, C. \& Gunter, B. (2013). Television can also be a factor in language change: Evidence from an urban dialect, în „Language”, 89 (3), p. 501-536, Crossref.

Stuart-Smith, J. \& Ota, I. (2014). Media models, 'the shelf', and stylistic variation in East and West: Rethinking the influence of the media on language variation and change, în Androutsopoulos, J. (ed.), Mediatization and Sociolinguistics Change, p. 127170 , de Gruyter, Berlin.

Stuart-Smith, J. (2016). Bridging the gap(s): The role of style in language change linked to the broadcast media, în Thøgersen, J., Coupland, N. \& Mortensen, J. (eds), Style, Media and Language Ideologies, 51-84, Novus, Oslo.

Swift, J. (1984 $\left.\left[1710^{1}\right]\right)$. The continual Corruption of our English Tongue, în Major Works, ed. A. Ross and D. Woolley, Oxford University Press, Oxford.

Thomas, G. (1991). Linguistic Purism, Longman, London/New York: 
Thøgersen, J., Coupland, N. \& Mortensen, J. (eds) (2016). Style, Media and Language Ideologies, Novus, Oslo.

Tieken-Boon van Ostade, I. (2006). Eighteenth-century prescriptivism and the norm of correctness, în van Kemenade, A. \& Los, B. (eds), The Handbook of the History of English, p. 539-557, Blackwell, Oxford, Crossref.

Tieken-Boon van Ostade, I. (2010). The usage guide: its birth and popularity, în „English Today”, 26 (2), p. 14-23, Crossref.

Tieken-Boon van Ostade, I. \& Percy, C. (eds) (2016). Prescription and Tradition in Language: Establishing Standards across Time and Space, Multilingual Matters, Bristol, Crossref.

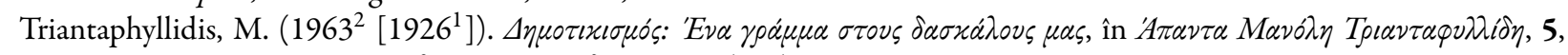

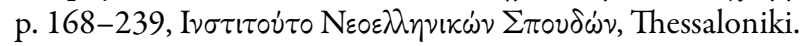

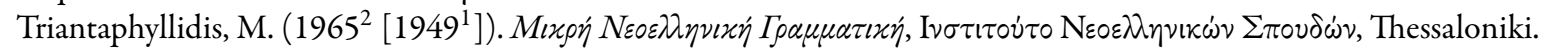

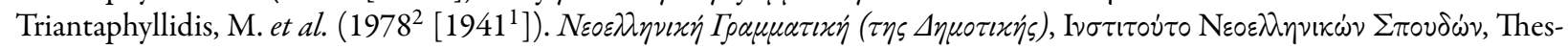
saloniki.

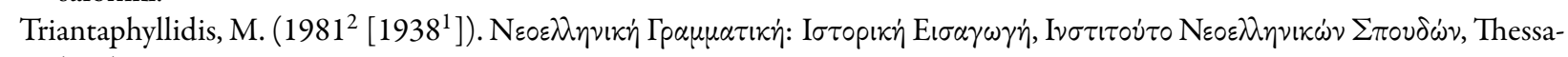
loniki.

Trudgill, P. (1983² [1974¹]). Sociolinguistics: An Introduction to Language and Society, Penguin Books, Harmondsworth.

Trudgill, P. (1999). Standard English: What it isn't, în Bex, T. \& Watts, R.J. (eds), Standard English: The Widening Debate, p. 117-128, Routledge, London.

Trudgill, P. (2003). A Glossary of Sociolinguistics, Oxford University Press, Oxford.

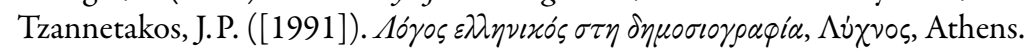

Veihinger, H. (1935). The Philosophy of 'As if': A System of the Theoretical, Practical and Religious Fictions of Mankind, translated by C.K. Ogden, $2^{\text {nd }}$ ed., Kegan Paul, London.

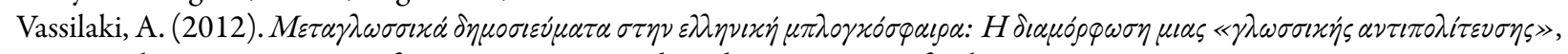
M.A. thesis, Department of Communication and Media, University of Athens.

Wardaugh, R. (1998 $\left.\left[1986^{1}\right]\right)$. An Introduction to Sociolinguistics, Blackwell, Oxford.

Zwicky, A. (2009). One right way, [online].

[Traducere de Adina Chirilă] 